\title{
VIRTUOSITY AND COMPOSER-PERFORMER COLLABORATION IN THE VIOLA WORKS OF DARIUS \\ MILHAUD AND PAUL HINDEMITH
}

\author{
BY
}

IRINA ANDREEVA

A thesis submitted to the Victoria University of Wellington in fulfilment of the requirements for the degree of Doctor of Musical Arts

Victoria University of Wellington (2017) 


\section{Abstract}

This thesis considers the position of Darius Milhaud's Viola Concerto No. 1, op. 108 (1929-30), and Viola Concerto No. 2, op. 340 (1955), in the modern viola repertoire. Milhaud's understanding of the viola as a solo virtuoso instrument is displayed particularly clearly in his two Concertos, which were specifically inspired by his relationships with two influential virtuoso violists of the twentieth centuryPaul Hindemith and William Primrose. A further, related issue that is explored, is the direct and indirect impact of Paganini's compositions on these two works.

Milhaud's virtuosic writing for the viola was strongly influenced by his friendships with these two musicians - Hindemith and Primrose - each of whom played a critical role in the emergence of a new breed of viola virtuosos during the course of the twentieth century. Milhaud's friendship with the first of these men, Paul Hindemith, produced not one, but two important pieces of the virtuoso viola repertoire: Milhaud's first Viola Concerto and Hindemith's Konzertmusik. Aspects of the cross-influence between composers and virtuoso performers are addressed here through a comparison of the technical and musical elements, as well as the structure of these two works. Another prominent violist of the twentieth century, William Primrose, who was nicknamed the 'Paganini of the Viola', commissioned Milhaud's second Viola Concerto. Primrose's desire for new concert repertoire for his instrument, together with his unequalled technical prowess, both impressed and inspired Milhaud, who wrote the Viola Concerto No. 2 with Primrose's technical virtuosity in mind. Strikingly, however, unlike the first Concerto, this work has been largely neglected for almost fifty years.

Significantly, both Milhaud's viola concertos display very strong technical similarities with Paganini's music written for the violin. Yet the position of Paganini's music in the viola repertoire, and the value and importance of his compositions for this instrument, traditionally ignites arguments amongst performers, critics and listeners alike. This is a complex issue, which raises various questions such as the physical suitability of Paganini's compositions for the original qualities of the viola, with its larger fingerboard, slower responding strings and heavier and shorter bow. In the present thesis this problem is addressed through a comparison of the 
technical elements used by Paganini in his writing for the viola (as exemplified in his Sonata per la Grand Viola) with techniques from his 24 Caprices, Milhaud's viola concertos, a selection of Primrose's transcriptions of Paganini's works and Hindemith's own compositions for viola.

By examining Milhaud's Viola Concerto No. 2 in relation to the evolution of the composer's writing for viola, from his encounters with Paganini's compositions to his collaboration with Hindemith, and, finally, to his engagement with Primrose, this thesis attempts to demonstrate that this work should be reintroduced to the contemporary virtuoso viola repertoire. 


\section{Table of Contents}

\section{Contents}

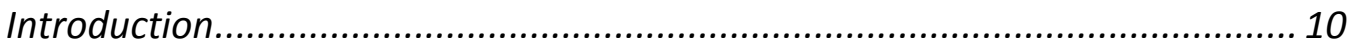

Chapter I. Models of Viola Virtuosity - Paganini, Primrose and Hindemith ...... 13 la.Paganini - Virtuoso Performer/Composer and Initiator of Virtuosity...... 13

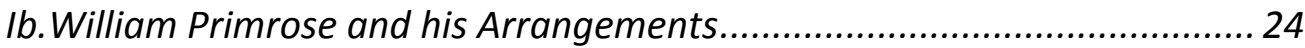

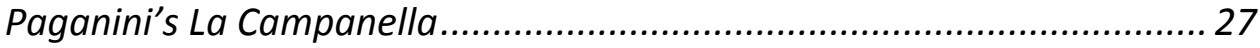

Arthur Benjamin's Jamaican Rumba .................................................. 31

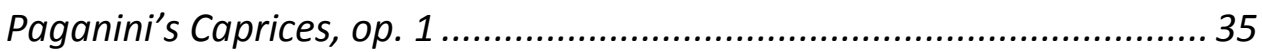

Ic. Paul Hindemith Konzertmusik for viola and large chamber orchestra,

Chapter II. The influence of virtuoso performers on composers. 54

Ila. Introduction 54

IIb. Darius Milhaud and Paul Hindemith: relationship. Darius Milhaud Viola Concerto No.1, Op.108 (1929) dedicated to Paul Hindemith 57

IIc. Darius Milhaud and William Primrose: relationship. 70

IId. Darius Milhaud. Viola Concerto No. 2, Op.340 (1954-1955) dedicated to William Primrose. 73

Chapter III. Aspects of virtuosity in the viola concertos by Darius Milhaud .... 100

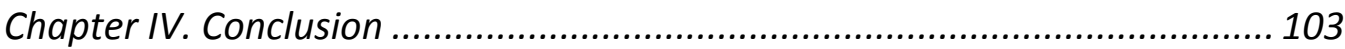

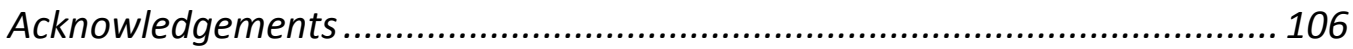

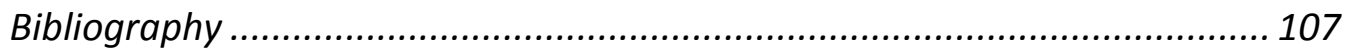




\section{List of Musical Examples}

1. Paganini, Sonata per la Grand' Viola e Orchestra, bars 16-20.

2. Paganini, Sonata per la Grand' Viola e Orchestra, bars 46-48.

3. Paganini, Sonata per la Grand' Viola e Orchestra, bars 54-56.

4. Paganini, Sonata per la Grand' Viola e Orchestra, bars 68-69.

5. Paganini, Sonata per la Grand' Viola e Orchestra, bars 72-75.

6. Paganini, Sonata per la Grand' Viola e Orchestra, bars 104-107.

7. Paganini, Sonata per la Grand' Viola e Orchestra, bars 112-116.

8. Paganini, Sonata per la Grand' Viola e Orchestra, bars 136-139.

9a. Paganini, Sonata per la Grand' Viola e Orchestra, bars 165-168.

9b. Paganini, 24 Caprices, op. 1, Caprice No. 1, bars 1-4.

10a. Paganini, 24 Caprices, op. 1, Caprice No. 1, bars 1-4.

10b. Paganini, Sonata per la Grand' Viola e Orchestra, bars 165-168.

11a. Paganini, 24 Caprices, op. 1, Caprice No. 6, bar 1.

11b. Paganini, Sonata per la Grand' Viola e Orchestra, bars 68-69.

12a. Paganini, Le Streghe, op. 8 (1813), Variation 3, bars 40-56.

12b. Paganini, Sonata per la Grand' Viola e Orchestra, bars 96-103.

13a. Paganini, arr. Primrose, La Campanella for Viola and Piano, bars 1-4.

13b. Paganini, Violin Concerto in B minor, op. 7, movement 3, 'La Campanella', bars 1-4.

14a. Paganini, arr. Primrose, La Campanella for Viola and Piano, bars 26-29.

14b. Paganini, Violin Concerto in B minor, op. 7, movement 3, 'La Campanella', bars 26-28.

15a. Paganini, arr. Primrose, La Campanella for Viola and Piano, bars 32-35.

15b. Paganini, Violin Concerto in B minor, op. 7, movement 3, 'La Campanella', bars 32-35.

15c. Paganini, arr. Primrose, La Campanella for Viola and Piano, bars 32-35.

16a. Paganini, arr. Primrose, La Campanella for Viola and Piano, bar 109.

16b. Paganini, arr. Primrose, La Campanella for Viola and Piano, bar 9. 
17. Benjamin, arr. Primrose, Jamaican Rumba for viola and piano, bars 9-13.

18. Benjamin, arr. Primrose, Jamaican Rumba for viola and piano, bars 27-30.

19a. Benjamin, arr. Primrose, Jamaican Rumba for violin and piano, bars17-26.

19b. Benjamin, arr. Primrose, Jamaican Rumba for viola and piano, bars 17-26.

20a. Benjamin, arr. Primrose, Jamaican Rumba for violin and piano, bars 41-43.

20b. Benjamin, arr. Primrose, Jamaican Rumba for viola and piano, bars 41-43.

21. Paganini, 24 Capricci Per Violino solo Op.1a, Facsimile, No.24, bars 1-11.

22. Paganini, edit. Ricci, 24Capricci per violin solo op.1, No.24, Bars 1-11.

23. Paganini, transcribed by L.Raby, 24 Caprices Opus 1, No. 24, Viola, bars 1-11.

24a. Paganini, edited by Ruggiero Ricci, 24 Capricci per violin solo Op.1, Violin, Var.9, bars 113-120.

24b. Paganini, transcribed by L.Raby, 24Caprices Op.1, Viola, No.42, Var.9, bars 128-139.

25a. Paganini, edited by Ruggiero Ricci, 24Capricci per violin solo Op.1, No.17, bars 24-2.

25b. Paganini, transcribed by L.Raby, 24 Caprices Op.1, Viola, No.1, bars 24-26.

26. Hindemith, Konzertmusik Op.48, $1^{\text {st }}$ movement, bars 21-24.

27. Hindemith, Konzertmusik Op.48, $1^{\text {st }}$ movement, bars 41-46.

28. Hindemith, Konzertmusik Op.48, $1^{\text {st }}$ movement bars 62-70.

29a. Hindemith, Konzertmusik Op.48, $2^{\text {nd }}$ movement, bars1-4.

29b. Hindemith, Konzertmusik Op.48, $2^{\text {nd }}$ movement, viola, bars 5-8.

30. Hindemith, Konzertmusik Op.48, $2^{\text {nd }}$ movement, bars 65-72.

31a. Hindemith, Konzertmusik Op.48, $3^{\text {rd }}$ movement, bars 1-8.

31b. Paganini, transcribed by Raby, 24 Caprices Op.1, Viola, No.3, bars 25-37.

32. Hindemith, Konzertmusik Op.48, $4^{\text {th }}$ movement, bars 1-8.

33. Hindemith, Konzertmusik Op.48, $4^{\text {th }}$ movement, bars 50-55.

34. Hindemith, Konzertmusik Op.48, $4^{\text {th }}$ movement, bars 65-73.

35. Hindemith, Konzertmusik Op.48, $5^{\text {th }}$ movement, bars 1-15.

36. Milhaud, Concerto pour Alto et Orchestra, edition pour Alto et Piano.

37. Milhaud, Concerto pour Alto et Orchestra, $1^{\text {st }}$ movement, bars1-9.

38. Milhaud, Concerto pour Alto et Orchestra, $1^{\text {st }}$ movement, bars 12-15.

39a. Milhaud, Concerto pour Alto et Orchestra, $1^{\text {st }}$ movement, bars 53-55. 
39b. Paganini, Sonata per la Grand'Viola, bar 60.

39c. Paganini 24 Caprices Op.1, No.4, bar 59.

40. Milhaud, Concerto pour Alto et Orchestra, $1^{\text {st }}$ movement, bars 42-45.

41. Milhaud, Concerto pour Alto et Orchestra, $1^{\text {st }}$ movement, bars 84-88.

42. Milhaud, Concerto pour Alto et Orchestra, $2^{\text {nd }}$ movement, bars 102-106.

43a. Milhaud, Concerto pour Alto et Orchestra, $2^{\text {nd }}$ movement, bars 140-141.

43b. Paganini, Sonata per la Grand' viola e orchestra, variation 3, bars 165-167.

44a. Milhaud, Concerto pour Alto et Orchestra, $2^{\text {nd }}$ movement, bars 122-123.

44b. Milhaud, Concerto pour Alto et Orchestra, $2^{\text {nd }}$ movement, bars 140-141.

44c. Paganini transcribed by L. Raby, 24 Caprices Op.1, Viola, No.1, bars 9-12.

45. Milhaud, Concerto pour Alto et Orchestra, $3^{\text {rd }}$ movement, bars148-151.

46a. Milhaud, Concerto pour Alto et Orchestra, $3^{\text {rd }}$ movement, bars 167-168.

46b. Paganini, Sonata per la Grand' Viola, bars 6-7.

47. Milhaud, Concerto pour Alto et Orchestra, $3^{\text {rd }}$ movement, bars 184-187.

48. Milhaud, Concerto pour Alto et Orchestra, $4^{\text {th }}$ movement, bars215-223.

49a. Milhaud, Concerto pour Alto et Orchestra, $4^{\text {th }}$ movement, bars229-233.

49b. Paganini, 24 Caprices Op.1, No.16, bars 16-18.

50. Milhaud, Concerto pour Alto et Orchestra, $4^{\text {th }}$ movement, bars 256-261.

51a. Paganini, 24 Caprices Op.1, No.16, bars 48-50.

51b. Milhaud, Concerto pour Alto et Orchestra, $4^{\text {th }}$ movement, bars 300-301.

52. Milhaud. Deuxiéme Concerto pour Alto et Orchestre, a William Primrose, title page in Milhaud's hand.

53. Milhaud, Deuxiéme Concerto pour Alto et Orchestre, a William Primrose. The manuscript of the piano reduction in the hand of Darius Milhaud with Primrose's fingering and other marks.

54. Milhaud, Deuxiéme Concerto pour Alto et Orchestre, $1^{\text {st }}$ movement, bars 1-3.

55. Milhaud, Deuxiéme Concerto pour Alto et Orchestre, $1^{\text {st }}$ movement, bars $13-$ 15.

56a. Milhaud, Deuxiéme Concerto pour Alto et Orchestre, $1^{\text {st }}$ movement, bars 7-15.

56b. Milhaud, Deuxiéme Concerto pour Alto et Orchestre, manuscript, $1^{\text {st }}$ movement, bars 9-16. 
57. Milhaud, Deuxiéme Concerto pour Alto et Orchestre, $1^{\text {st }}$ movement, bars 2528.

58. Milhaud, Deuxiéme Concerto pour Alto et Orchestre, 1st movement, bars 3032.

59. Milhaud, Deuxiéme Concerto pour Alto et Orchestre, 1st movement, bars 3840.

60. Milhaud, Deuxiéme Concerto pour Alto et Orchestre, 1st movement, bars 4748.

61. Milhaud, Deuxiéme Concerto pour Alto et Orchestre, 1st movement, bar 47.

62. Milhaud, Deuxiéme Concerto pour Alto et Orchestre, 1st movement, bars 5461.

63. Milhaud, Deuxiéme Concerto pour Alto et Orchestre, 1st movement, bar 58.

64. Milhaud, Deuxiéme Concerto pour Alto et Orchestre, 1st movement, bar 61 .

65. Milhaud, Deuxiéme Concerto pour Alto et Orchestre, $1^{\text {st }}$ movement, bar 66 .

66. Milhaud, Deuxiéme Concerto pour Alto et Orchestre, 1st movement, bar 69 .

67. Milhaud, Deuxiéme Concerto pour Alto et Orchestre, 1st movement, bars 5960.

68. Milhaud, Deuxiéme Concerto pour Alto et Orchestre, 1st movement, bar 65.

69a. Milhaud, Deuxiéme Concerto pour Alto et Orchestre, 1st movement, bar 65 .

69b. Milhaud, Deuxiéme Concerto pour Alto et Orchestre, 1st movement, bar 65.

70. Milhaud, Deuxiéme Concerto pour Alto et Orchestre, 2nd movement, bars18.

71. Milhaud, Deuxiéme Concerto pour Alto et Orchestre, 2nd movement, bars 41-43.

72. Milhaud, Deuxiéme Concerto pour Alto et Orchestre, 2nd movement, bar 57.

73. Milhaud, Deuxiéme Concerto pour Alto et Orchestre, 2nd movement, bar 67.

74. Milhaud, Deuxiéme Concerto pour Alto et Orchestre, 2nd movement, bars 74-87.

75. Milhaud, Deuxiéme Concerto pour Alto et Orchestre, 3rd movement, bars 4243.

76. Milhaud, Deuxiéme Concerto pour Alto et Orchestre, 3rd movement, bars 4143. 
77. Milhaud, Deuxiéme Concerto pour Alto et Orchestre, 3rd movement, bars 5961.

78. Milhaud, Deuxiéme Concerto pour Alto et Orchestre, 3rd movement, bars 8687.

79. Milhaud, Deuxiéme Concerto pour Alto et Orchestre, 3rd movement, bars 9899.

80. Milhaud, Deuxiéme Concerto pour Alto et Orchestre, 3rd movement, bar 117.

81. Milhaud, Deuxiéme Concerto pour Alto et Orchestre, 3rd movement, bars $118-123$.

82. Milhaud, Deuxiéme Concerto pour Alto et Orchestre, 3rd movement, bar 149.

83. Milhaud, Deuxiéme Concerto pour Alto et Orchestre, 3rd movement, bars 162-169.

84. Milhaud, Deuxiéme Concerto pour Alto et Orchestre, 4th movement, bars 15.

85. Milhaud, Deuxiéme Concerto pour Alto et Orchestre, 4th movement, bars 2428.

86. Milhaud, Deuxiéme Concerto pour Alto et Orchestre, 4th movement, bars 4150.

87. Milhaud, Deuxiéme Concerto pour Alto et Orchestre, 4th movement, bars 5158.

88. Milhaud, Deuxiéme Concerto pour Alto et Orchestre, 4th movement, bars 7578.

89. Milhaud, Deuxiéme Concerto pour Alto et Orchestre, 4th movement, bars 7980.

90. Milhaud, Deuxiéme Concerto pour Alto et Orchestre, 4th movement, bars 9596.

91. Milhaud, Deuxiéme Concerto pour Alto et Orchestre, 2nd movement, bars 108-110.

92. Milhaud, Concerto pour Alto et Orchestre, 4th movement, bars 53-56.

93a. Paul Hindemith, Konzertmusik Op.48, 1st movement, bars 64-70.

93b. Paul Hindemith, Der Schwanendreher, 1st movement, bars 89-94. 


\section{Introduction}

The idea of embarking upon a doctoral degree in viola performance was initiated by my active performing career on the instrument and by the constant search for new repertoire for my own recitals. Like the majority of my professional colleagues, I have experienced a variety of roles in my career as a working musician - orchestral tutti violist, leader of a section, chamber musician (both as violinist and violist) and soloist. Gradually, with many years of experience, came an understanding of the main purpose of my profession - to attract an audience and satisfy that audience's musical expectations and

desire for entertainment. Through the selection of programmes for my recitals, evaluating the response of the audience, and attending the concerts of colleagues and renowned soloists, I reached a simple conclusion: to be successful, one must not only provide an outstanding performance but also be prepared to bring to the audience something new and different.

It was during this on-going search for fresh repertoire for my recitals that I came across Darius Milhaud's Quatro Visages, op. 238 (1942-43), four pieces for viola and piano offering aural portraits of women. I was attracted to this music's expressiveness and vivacity, its technical demands, and the beauty of the melodic lines embedded with witty quotations. Subsequently, I sought out further works by Milhaud, and it was whilst looking through the rarely performed virtuoso viola repertoire that I encountered his Viola Concertos. Almost immediately, I was intrigued by the obvious differences in the fate of these two works, regardless of the similarities in the history of their creation.

During further investigations of Milhaud's compositions, I discovered undeniable signs of the cross-influence between Milhaud and Paul Hindemith, his intriguing silence about his encounters with William Primrose during the creation of the second Concerto, and the large number of almost exact quotations from Paganini's Caprices in that same work. This unusual combination of biographical facts, musical charades and my own curiosity became the force that drew me through my degree. At the back of my mind there was a hope that I would rediscover a forgotten virtuoso concerto in the viola repertoire, and, of course, there was a chance of revealing that the Concerto was a one-off unsuccessful piece by one of the great composers of the twentieth century. At the early stage of my research I didn't realise that I 
would need to make a thorough investigation of the three other prominent figures of the musical virtuoso world: Nicolò Paganini, Paul Hindemith and William Primrose. However, the close connections and very strong influences - both direct and indirect - that I discovered, gave me little possibility of avoiding consideration of these aspects; therefore, many chapters of this dissertation are dedicated to a topic other than Milhaud and his music.

For that reason, after this Introduction, Chapter I is subdivided into separate sections, each of which discusses the relationships between composers and virtuoso performers. The first section is dedicated to Nicolò Paganini as one of the early initiators of this virtuosity, with an emphasis on his Sonata per La Grand' Viola and Orchestra and transcriptions for viola of his violin caprices. The indirect influence of Paganini on Milhaud became evident to me during my research, and I have aimed to create a sensible and objective link between Paganini and Milhaud's music. The second section is centred on one of the most prolific virtuoso violists, William Primrose, and his arrangements of pieces from the violin repertoire for the viola. Finally, the third section of Chapter I is dedicated to the history of the relationship and friendship between Darius Milhaud and Paul Hindemith, a successful professional and personal pairing that produced not one, but two great pieces of the virtuoso viola repertoire: Milhaud's Viola Concerto No. 2, op. 340 (1954-55) and Hindemith's Konzertmusik, op. 48 (1930).

Chapter II discusses aspects of the influence of virtuoso performers on composers, illustrated by examples taken from Milhaud's first and second Concertos for viola. In the first section of this part I explore the roots of Milhaud's fascination with virtuosity, before moving on to outline his friendships and working relationships with Paul Hindemith and William Primrose, respectively. In approaching the latter topic, I was interested to trace what was known about those relationships and, in doing so, found a significant amount of information regarding the friendship between Darius Milhaud and Paul Hindemith, largely as documented by both men in their autobiographies.

Chapter II also provides background for a discussion and comparison of Milhaud's Viola Concerto No. 1, op. 108 (1929) with Hindemith's Konzertmusik, before moving on to consider the relationship between Milhaud and Primrose. This was, however, a very different matter when compared to his relationship with Hindemith, as there is very little information available, with only scant material obtainable from their letters and from an 
interview with Milhaud's widow, Madeleine Milhaud. Thus, the third section of Chapter II, while touching upon the Milhaud and William Primrose's relationship - largely centres on the Second Concerto.

In Chapter III, aspects of virtuosity in Milhaud's Second Viola Concerto are discussed in some detail with a particular focus being a comparison of this Concerto with other pieces of the virtuoso viola repertoire, including works that I have performed myself: by Darius Milhaud, Paul Hindemith and Nicolò Paganini, as well as a selection of William Primrose's arrangements of works by Nicolò Paganini, Arthur Benjamin and Heitor Villa-Lobos.

Selecting similar technical elements from these pieces, and comparing and appraising them, helped me to justify the conclusions I reached regarding the level of technical difficulty, suitability of techniques for the viola and musical aspects of this concerto.

Finally, Chapter IV provides a summary of my lecture recitals and performancer of this music; in doing so, it presents the highlights of my journey as well as my final conclusions on Milhaud's Second Viola Concerto and its place in the virtuoso viola repertoire. 


\section{Chapter I. Models of Viola Virtuosity - Paganini, Primrose and Hindemith}

In order to better understand the roots of Milhaud's virtuosic writing for the viola, this chapter is dedicated to three distinct models of virtuoso music - Nicolò Paganini, William Primrose and Paul Hindemith. In each case, the historical aspect of their impact on virtuoso viola music is considered, together with an exploration of the ways in which specific relationships between these composers and virtuoso performers influenced their own musical style, and, in addition, how these developments were later to impact upon Milhaud's virtuoso writing for the viola.

\section{Ia. Paganini - Virtuoso Performer/Composer and Initiator of Virtuosity}

As an advanced violin student who had studied the instrument at the Paris Conservatoire under Henri Berthelier, Darius Milhaud (1892-1974) was no doubt very familiar with Paganini's music. ${ }^{1}$ Indeed, it would be reasonable to assume that Paganini's works counted amongst Milhaud's first experiences performing virtuoso music and one of the earliest virtuoso influences on his music.

Paganini has been held up by a number of writers as the quintessential model of the virtuosic performer; historians cite him as the initiator of virtuosity as we know it today. ${ }^{2}$ For example, Laurence Le Diagon-Jacquin, in her article 'Virtuosity and Inventiveness in the Pianistic Universe of the Nineteenth Century,' describes Paganini as 'a violinist who initiated the craze for virtuosity. ${ }^{3}$ While another article, 'Piano in the Concert Hall' by Stephen Zank, traces the progression of piano recitals from house performances to concert halls, alongside the piano's transformation into a virtuoso concert instrument. Zank guides us through the musical life of the major capital cities of the eighteenth and nineteenth centuries: London,

\footnotetext{
${ }^{1}$ Jeremy Drake, 'Milhaud, Darius,' Grove Music Online, www.oxfordmusiconline.com, accessed 12 January 2016.

${ }^{2}$ See, for example, Stephen Samuel Stratton, Nicolo [sic.] Paganini. His Life and Work (Westport, Connecticut: Greenwood Press,1971); John Sudgen, Niccolo Paganini. Supreme Violinist or Devil's Fiddler? Work (Neptune City, N.J Midas Books, 1980); Alan Kendall, Paganini: A Biography (London, Chappell: Elm Tree Books, 1982o); Abraham Veinus, Victor book of Concertos (Simon and Shuster, 1948, Ney York) 325-327.

${ }^{3}$ Laurence Le Diagon-Jacquin, 'Virtuosité et invention dans I'univers pianistique du XIXe siècle,' Analyse musicale 52 (2005), 62-75.
} 
Vienna, Paris and New York. In the section of his work dedicated to Paris, he describes how the piano, as an emerging solo virtuoso recital instrument, was forced to compete with another well received and loved virtuoso solo instrument - the violin. Referring to Nicolò Paganini's (1782-1840) appearances in Vienna in 1828, Zank states that "a concert instrumental repertory was finally enshrined and Vienna's own keyboard players were thereby presented with a new and startling set of challenges". ${ }^{4}$

In her book Virtue or Virtuosity, Jane O'Dea says that early nineteenth-century virtuosi often sacrificed the expressiveness of music to the 'apparent ease and rapidity', unlike Paganini, whose performances fascinated concertgoers and fellow musicians 'not just by his technical wizardry, but also by the expressive powers of his cantilena'. ${ }^{5}$

As noted by various scholars, even at eleven years of age Paganini was an accomplished virtuoso violinist, which can be confirmed by the fact that the 'Pride of Italy', Alessandro Rolla, after he overheard an astonishing Paganini's sight reading of the manuscript of Rolla's latest violin concerto, said that 'he could teach the boy nothing; it would waste his time... ${ }^{6}$ Another interesting account of Paganini's virtuosity and the way he was admired and accepted by his contemporaries appears in the article by Cliff Eisen. He quotes an 'opinion of an eminent musician upon modern violinists, to the year 1831' published in The Times in July $1836^{7}$. Seventeen prominent violinists were listed and each name bearing the list of their best qualities as a performer: 'Viotti... Vigorous energy, grand bowing, extraordinary execution and masterly style. Rode.... Bold tone, vigour and elegance. Spohr... Grandeur, vigour, elevation of style. Paganini... Everything. ${ }^{8}$

Paganini's interest in the use of the viola as a solo instrument, which culminated in 1834 when he composed Sonata per La Gran Viola, was not sudden. It seems likely that it had been ignited in the 1790s while he was still a student with the Italian viola and violin virtuoso Alessandro Rolla (1757-1841) who was well known for his progressive

\footnotetext{
${ }^{4}$ Stephen Zank, 'The Piano in the Concert Hall', in Piano Roles: A New History of the Piano ed. James Parakilas et al, (New Haven, CT \& London: Yale University Press, 2002), 241, 243, at 237-251.

5 Jane O'Dea Virtue or Virtuosity. Explorations in the Ethics of Musical Performance (Greenwood Press, Westport, Connecticut. London, 2000) Chapter 3, p.41

${ }^{6}$ Stephen S. Stratton, Nicoli Paganini. His life and work. (Greenwood Press, Westport, Connecticut, 1971), pp. $10-11$.

${ }^{7}$ The Times (London), 20 July 1836, p.7, col. A

${ }^{8}$ Cliff Eisen, 'The Rise (and Fall) of the Concerto Virtuoso in the Late Eighteenth and Nineteenth Centuries', in The Cambridge Companion to the Concerto ed.,Simon P. Keefe(Ney York: Cambridge University Press, 2005) pp.179-180
} 
compositions for the viola. ${ }^{9}$ Paganini's fascination with the viola was short-lived, considering that the Sonata per La Grand Viola was his only significant composition for the solo viola. However, this composition is particularly important for viola's transformation into a virtuoso instrument. By utilising techniques from his own violin compositions, Paganini set enormously high technical standards for the instrument. His earliest composition featuring the viola is his Serenata in C for viola, violoncello and guitar, which dates from before 1808 according to the Grove Music Online, while a decade later, in 1818-20 he wrote his Quartet No.15 in A minor for viola concertante, violin, cello and guitar ${ }^{10}$, and another decade later Terzetto concertante for viola cello and guitar (1833). It is worth noting, however, that none of these works is as technically demanding as his Sonata per la Grand' Viola et Orchestra, a piece which is to be discussed in more depth below.

In the early 1800s Paganini acquired the so-called 'Mendelssohn viola' - an instrument made by Antonio Stradivari in $1731 .{ }^{11}$ Naturally, he wanted to obtain a substantial piece of music that would serve to showcase his new instrument, and for that purpose commissioned a viola concerto from Hector Berlioz. The resultant composition was Harold in Italy, op. 16, a symphony with viola obbligato composed in 1834. Paganini regarded the piece as too simple for his brilliant technique; so, in order to satisfy the brief; both to show off the Stradivari, but also - and at least as importantly - to showcase his own virtuosic playing, that same year, while in London, he himself composed a much more complex opus in terms of virtuoso viola technique. ${ }^{12}$

The work in question was his Sonata per La Grand' Viola e Orchestra. In writing this piece, Paganini turned to a musical form that he commonly used in his compositions, that of the theme and variations. It seems clear that his fondness for this type of composition lay in the form's capacity for highlighting his own virtuosic playing. For, having selected one, generally very popular theme from one of the latest operas, Paganini then was able to

\footnotetext{
9 Monica Cuneo, 'Alessandre Rolla and the Viola' http://www.viola -in-music.com//Alessandro-Rolla.html (08/02/2016)

${ }^{10}$ This is the last quartet in the series of 15 and viola takes the leading role in this quartet.

${ }^{11}$ Paganini-Mendelsohnn Viola 1831 this viola along with the Paganini-Desaint violin of Foundation 1680, the Paganini-Comte Cozio di Salabue violin of 1727, and the Paganini-Ladenburg cello of 1731, comprise a group of instruments referred to as The Paganini Quartet; on loan to Kazuhide Isomura of the Tokyo https://beskurt.files.wordpress.com/2008/12/stradivari-enstrumanlari.pdf (22/02/2016)

12 Mauro Righini,'Paganini, Berlioz and the Grand Viola,' Quaderni dell'Istituto di Studi Paganiniani 13 (2001), $62-9$.
} 
create multiple variations, generally dedicating each of those variations to one or two different virtuoso techniques.

Comparing Sonata per La Grand'Viola e Orchestra with some of the most popular virtuoso pieces from Paganini's violin repertoire, such as La Campanella, Le Streghe and his 24 Caprices op. 1 for violin, it seems clear that he did not differentiate between violin and viola when composing, despite such obvious discrepancies regarding the size of the two instruments, the shorter and heavier viola bow and the latter instrument's lower register. Yet in my own practical research into this repertoire, I experimented with playing similar technical elements on the violin and viola, respectively, and investigated the various ways of executing them in consideration to aforementioned differences between the two instruments. The discussion that follows will highlight these virtuosic techniques and outline why they are particularly challenging for the viola.

Paganini's Sonata per La Grand' Viola e Orchestra, op. 35, is a work in one movement that is divided into three sections: Introduzione (Larghetto - Recitativo a piacere), Cantabile (Andante sostenuto) and a Tema con variazioni, comprising a theme, three variations and a coda. As its title suggests, the Sonata is scored for orchestra and viola. After an orchestral opening that introduces the main theme of the work, the viola entrance establishes the parameters of the piece with a sonorous, operatic recitative starting in $6^{\text {th }}$ position on the $A$ string (see Mus. ex. 1). Within the first phrase, Paganini covers the entire range of the viola with a shift from the open string $C$ to the $8^{\text {th }}$ position on the $A$ string, a technical transition that requires advanced shifting techniques and a perfect knowledge of the fingerboard. The eight lines of the short Recitativo a piacere section play the role of an intriguing preamble to the main body of the Sonata. Paganini provides a hint of the variety of exciting techniques he will be employing later in the work: harmonics, virtuoso and 'singing' passages covering the entire range of the viola, trills, high positions and double stops. Within these eight lines, Paganini changes tempo twice, from Recitativo a piacere to Piú mosso to Presto. 


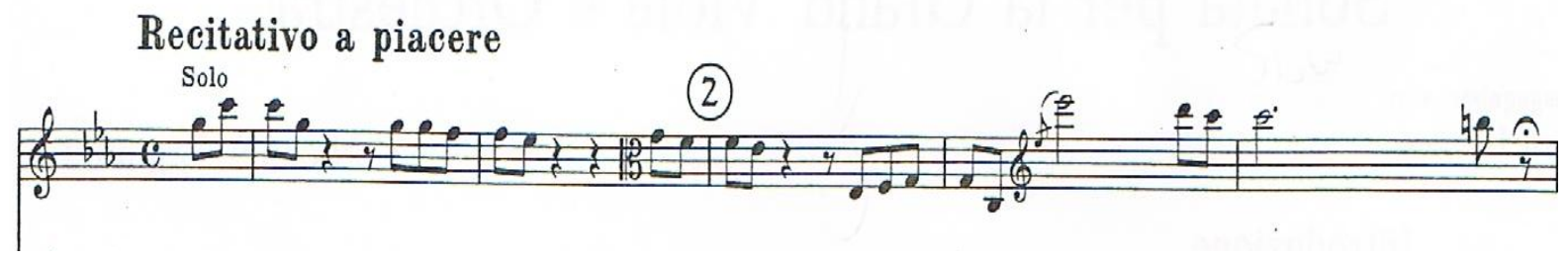

The next section of the Sonata, the Cantabile, is based on the advanced doublestopping technique (see Mus. ex. 2). Here, Paganini uses various techniques to create multiple parts, melodic lines and chords: one string scale, from the first to fifth position against a lower open string, and - in what is a special challenge for both viola or violin - the combination of double stops and left hand pizzicato (see Mus. ex. 3). The larger fingerboard of the viola makes it particularly challenging to reach the pair of lower strings with the little finger while playing double stops on two upper strings. Furthermore, the thickness of $\mathrm{C}$ and G strings requires extra 'muscle' work from the little finger when creating a strong pizzicato sound without interrupting the tune played on the top two strings.

Mus. ex. 2. Paganini, Sonata per la Grand' Viola e Orchestra, viola part, bars 46-48.

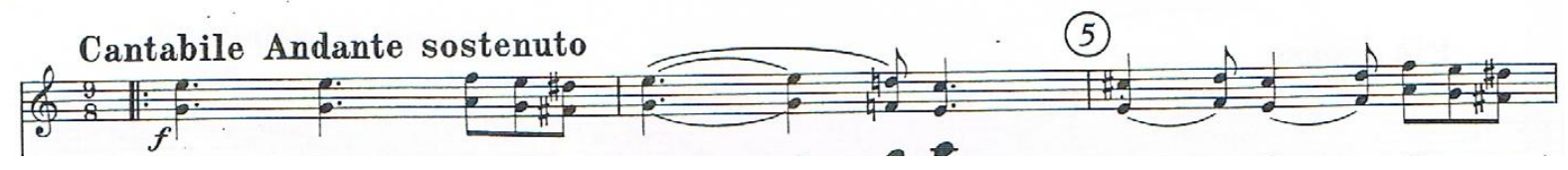

Mus. ex. 3. Paganini, Sonata per la Grand' Viola e Orchestra, viola part, bars 54-56.

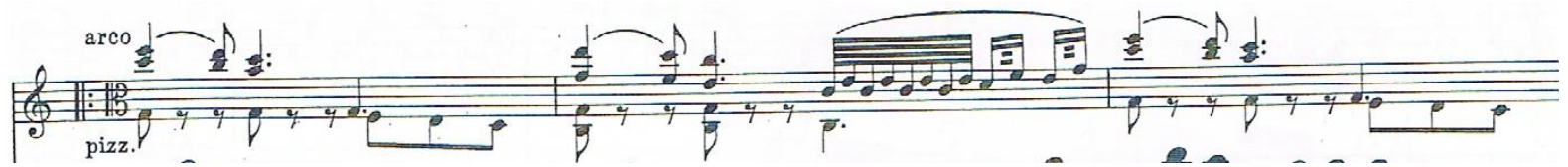

Another common feature of Paganini's music - the so-called 'devils trill', a technique where the violinist is required to play simultaneous rhythmically organised trills on two nearing strings, or, very often, a tune on one of these strings accompanied by trills on

\footnotetext{
${ }^{13}$ All musical examples from this work are taken from Ulrich Drüner's edition: Nicolò Paganini, Sonata per la Grand' Viola e Orchestra, piano reduction with solo part (Mainz: Schott, 1974).
} 
another, appears in this movement (see Mus. ex. 4). ${ }^{14}$ While the technique itself is simple enough when played on the violin, Paganini's transposition of this quintessential violin technique to the viola makes it much more difficult, however, due to the slower responding lower strings of the viola.

Mus. ex. 4. Paganini, Sonata per la Grand' Viola e Orchestra, viola part, bars 68-69.

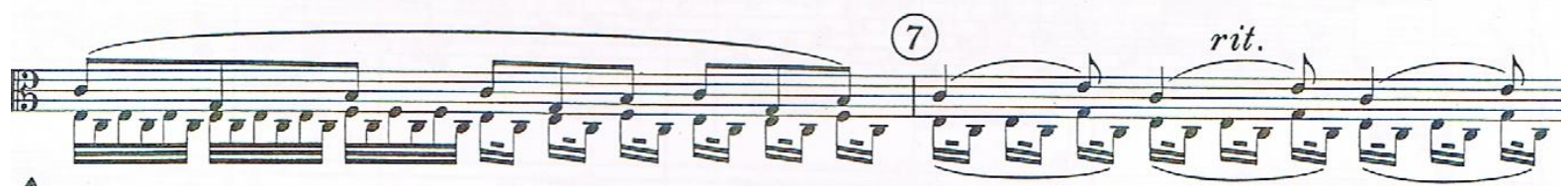

The Andante that follows launches the theme and variations, introducing the main theme in its original form (see Mus. ex. 5).

Mus. ex. 5. Paganini, Sonata per la Grand' Viola e Orchestra, viola part, bars 72-75.

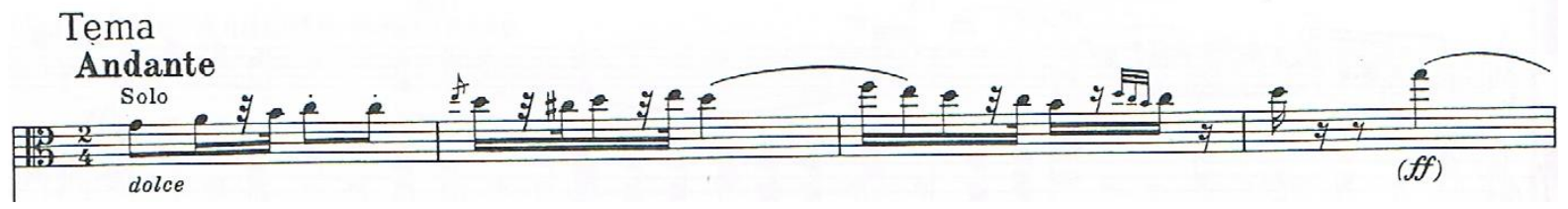

Predictably, in the variations that follow, Paganini varies this march-like, operatic tune in the viola part by transporting it to different octaves and positions, as well as by applying different dynamics. The last appearance of the theme at the end of the Andante is the first example of perhaps the most challenging technique of this Sonata-harmonics. Paganini favoured this technique and used it in many of his compositions in the way described by Baillott as 'the most fortuitous and at the same time most ingenious'. ${ }^{15}$

Not surprisingly, the major difference between performing harmonics on the violin and on the viola, respectively, is the size of the instrument. The larger fingerboard of the viola creates larger shifts and extensions of the fingers, thus making it challenging for the

\footnotetext{
14 This technically very demanding element was invented and first utilised by Giuseppe Tartini (1692-1770) in his Violin Sonata in G minor (composed c. 1714), commonly known as the 'Devil's Trill',' see "'Devil's Trill'” Sonata (Trillo del Diavolo or Sonata del Diavolo),' in The Oxford Dictionary of Music, www.oxfordmusiconline (accessed 13 January 2016).

${ }^{15}$ Pierre Marie Francois de Sales Baillot, The Art of The Violin, (Evanston: Northwestern University Press 1991), Chapter 24, p.404
} 
performer to maintain good intonation. Thicker strings require more pressure from the first finger when the first and fourth fingers are involved. Maintaining a balance between the pressure from the first finger and the light touch of the fourth is yet another challenge posed by executing harmonics on the viola.

In Variation 1, for the first time Paganini introduces a deconstructed theme with the character indication staccato con forza, using a forte dynamic marking and heavy staccato bow strokes at the heel of the bow with the extra challenges of a string crossing and position changing (see Mus. ex. 6).

Mus. ex. 6. Paganini, Sonata per la Grand' Viola e Orchestra, viola part, bars 104-107.

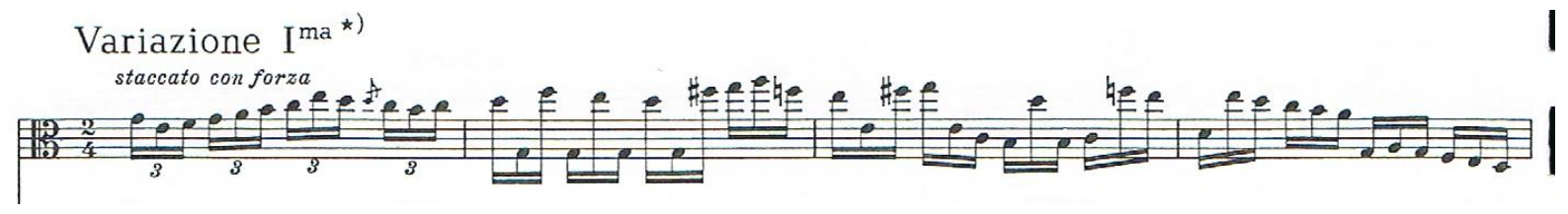

Naturally, given the character of this theme, the performer experiences a strong desire to play it in a fast tempo. The majority of violists today execute this theme at the tempo of crotchet equals between 100 and $120 .{ }^{16}$ As I soon discovered for myself, however, that this provides a challenge given that Paganini employs an echo effect, bringing back the same melody in the piano dynamic and entirely comprised of harmonics (see Mus. ex. 7).

Mus. ex. 7. Paganini, Sonata per la Grand' Viola e Orchestra, viola part, bars 112-116.

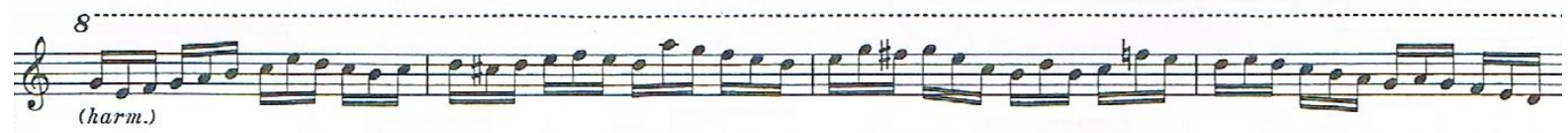

The second variation of the Sonata is headed 'Minore piú Lento' and employs extensive use of high-position playing. At its opening, the theme commences in the $6^{\text {th }}$ position and gradually moves up to the $10^{\text {th }}$ position. This is a highly unusual use of position playing on the viola, and one that is much more common for violin. Perhaps in this case Paganini tried to impersonate the sound of the E string of the violin with its clarity,

\footnotetext{
${ }^{16}$ Amongst many recordings available online, I particularly enjoyed these two outstanding performances: Paganini. Sonata per la Gran Viola Anna Serova available from https://www.youtube.com/watch?v=RzIzMRxgF9Y; Nicolo Paganini. Sonata per la Grand Viola Op. 35 Salvatore Accardo, Contraviola MS 70 available from $h$ ttps://www.youtube.com/watch? $v=401 \mathrm{Fx} 06 \mathrm{Gec} 8$ (accessed25/01/2016)
} 
sweetness and brilliance of the coloratura soprano, where the A string of the viola can be described as a dramatic soprano (See Mus. ex. 8).

Mus. ex. 8. Paganini, Sonata per la Grand' Viola e Orchestra, viola part, bars 136-139.

Minore più lento

(Variazione $\mathrm{II}^{\mathrm{da}}$ )

(14)

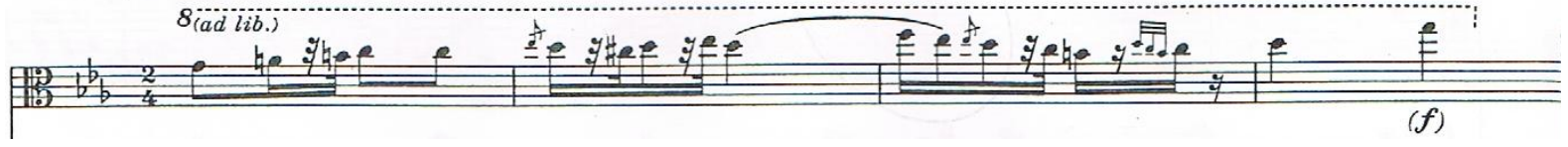

Variation 3 is an excellent example of Paganini's successful adoption of a violin technique for the viola. This same figuration featured in his Caprice No. 1 (see Mus. exs. 9a and 9b).

Mus. ex. 9a. Paganini, Sonata per la Grand' Viola e Orchestra, viola part, bars 165-168.

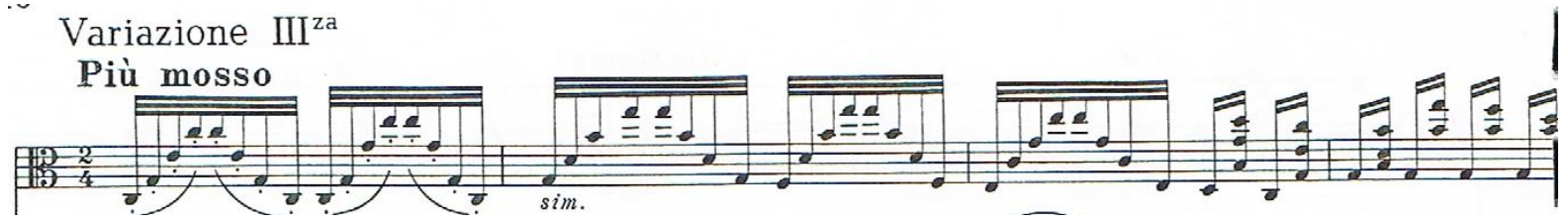

Mus. ex. 9b. Paganini, 24 Caprices, op. 1, Caprice No. 1, bars $1-4{ }^{17}$

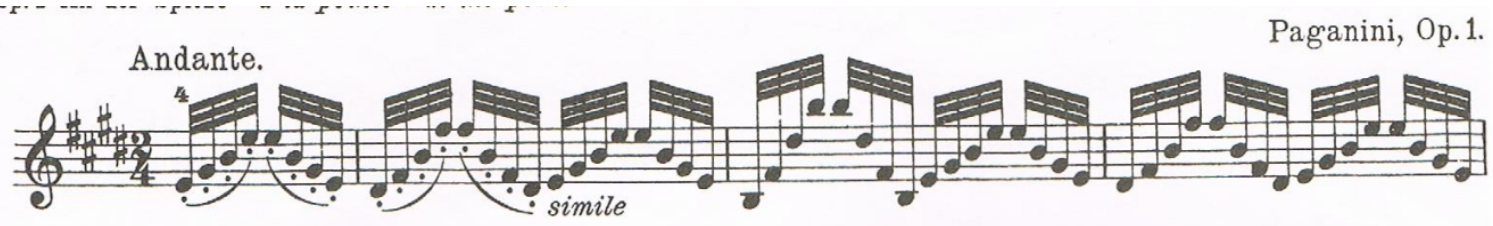

By using the comfortable key of $\mathrm{C}$ major, Paganini makes an adaptation of this challenging technique from the violin repertoire playable on the viola. As part of this process, he also omits non-typical extensions between the lower and upper notes of arpeggiato chords.

The coda is written in the brilliant style characteristic of Paganini's music and is a patchwork of techniques from different variations of the Sonata: devil's trills as in Andante

\footnotetext{
${ }^{17}$ All musical examples from the 24 Caprices are taken from the facsimile edition of the original Ricordi edition (Milan, 1820): Nicolò Paganini, 24 capricci per violino solo, Performers' Facsimiles, 244 (New York: Broude Brothers, 2002).
} 
sostenuto, ascending sequences of cords reminiscent of these from third variation and rapid descending passages. The festive atmosphere of the coda is interrupted by the brief appearance of the main theme just before the concluding three octaves $\mathrm{C}$ major arpeggio.

In order to further illustrate Paganini's use of the viola as a virtuoso solo instrument, it is useful at this point to draw some direct comparisons with his violin virtuoso technique. To that end, the following discussion compares examples of the techniques drawn from Paganini's Sonata per La Grand' Viola with techniques used in some of his most popular pieces for the violin, including the 24 Caprices, op. 1, which although judged 'unplayable' at the time of their first publication in 1820 , subsequently became "the "Bible" of all violinists. $^{18}$

Musical examples 10a and 10b demonstrate the arpeggiato chords technique combined with the ricochet bow stroke used by Paganini in many of his compositions, the most memorable example of which is Caprice No. 1, op. 1 (see Mus. ex. 10). An additional challenge in the violin version of this technique is the stretch between the first and the fourth fingers in the arpeggiato chords and the challenging key of E major.

Mus. ex. 10a. Paganini, 24 Caprices, op. 1, Caprice No. 1, bars 1-4.

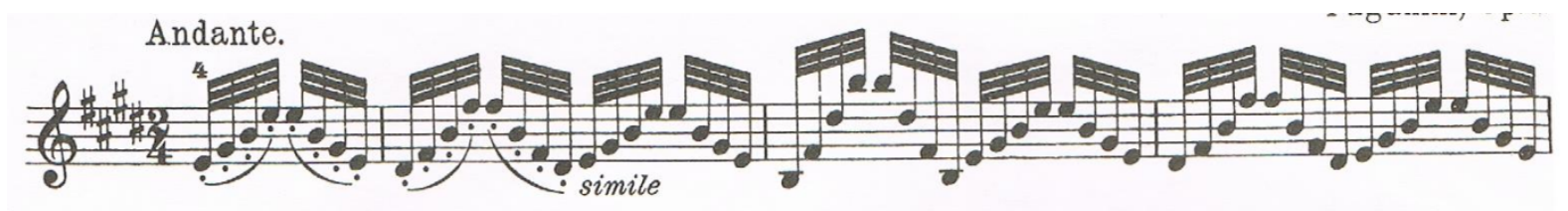

In the viola version of this technique, Paganini omits one of his favourite tricks - an interval larger than an octave between the lower and upper notes of the arpeggiato chords. He also uses a more 'comfortable' key for executing this technical element on the viola, C major (see Mus. ex. 10b).

${ }^{18}$ Edward Neill, 'Paganini, Nicolò', Grove Music Online, www.oxfordmusiconline.com (accessed 13/01/2016). 
Mus. ex. 10b. Paganini, Sonata per la Grand' Viola e Orchestra, viola part, bars 165-168.

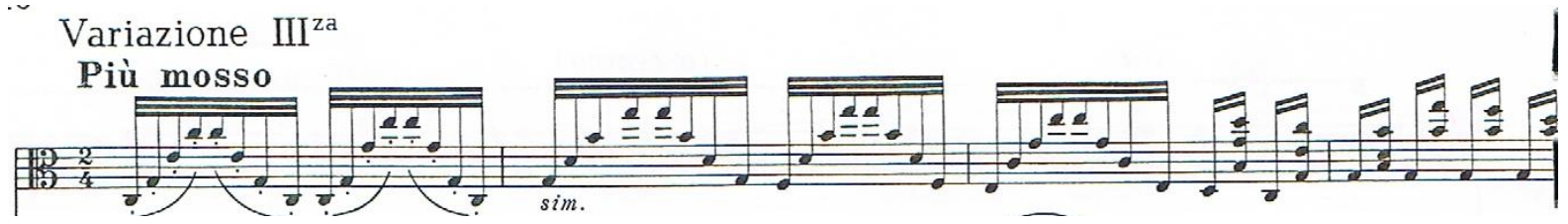

Musical examples 11a and 11b exhibit a technique where the melody in the upper voice is accompanied by rhythmically organised trills in the lower voice. The complication in the violin version is the use of non-typical extensions in both lines (see Mus. ex. 11a). Once again, Paganini does not employ non-typical extensions and contractions in the viola version of this technical element (see Mus. ex. 11b).

Mus. ex. 11a. Paganini, 24 Caprices, op. 1, Caprice No. 6, bar 1.

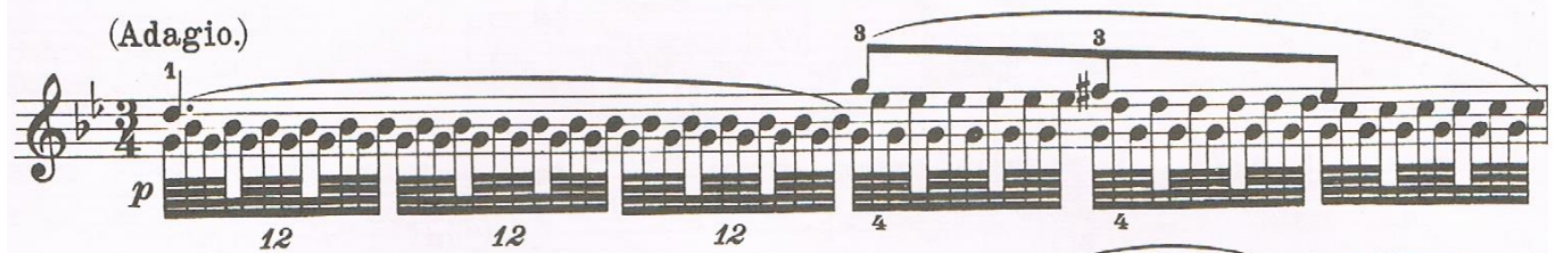

Mus. ex. 11b. Paganini, Sonata per la Grand' Viola e Orchestra, viola part, bars 68-69.

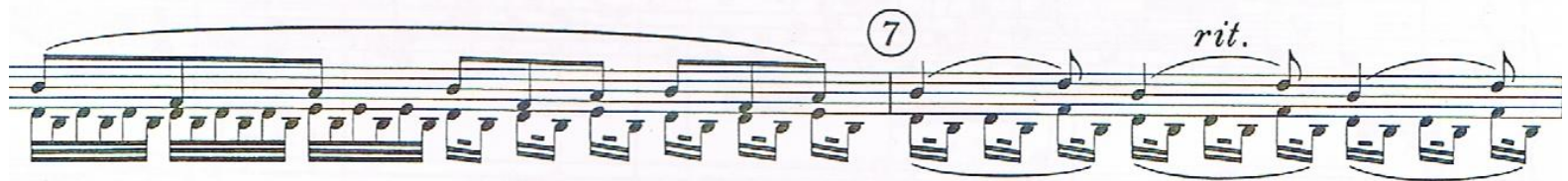

Harmonics are commonly featured in Paganini's compositions. Musical examples 12a and $12 \mathrm{~b}$ illustrate similarities in the usage of harmonics in Le Streghe, op. 8 (1813) for violin and piano, and the Sonata per la Grand' Viola. Not only does the theme of the former work provide an example of the usage of a similar technique, but it also resembles the main theme of the Sonata per la Grand Viola melodically (see Mus. ex. 12b). 
Mus. ex. 12a. Paganini, Le Streghe, op. 8 (1813), violin part, Variation 3 bars 40-56. ${ }^{19}$

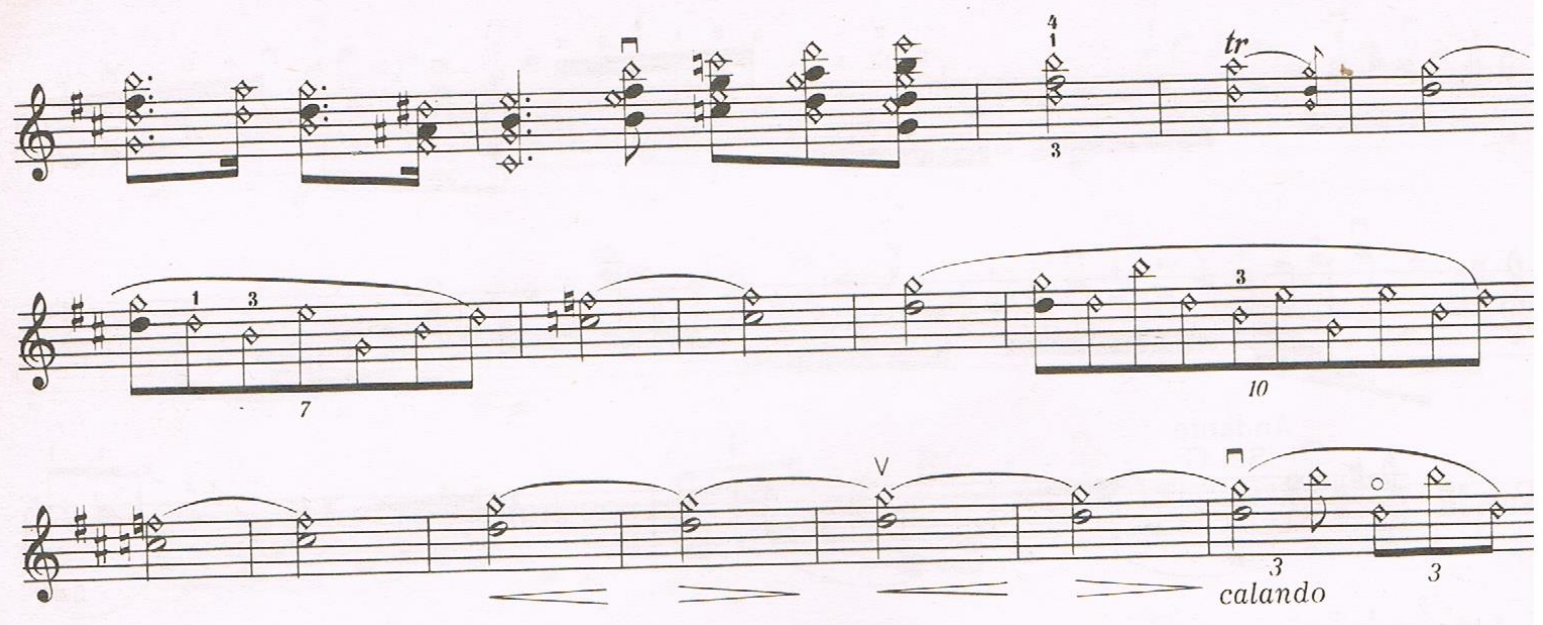

Mus. ex. 12b. Paganini, Sonata per la Grand' Viola e Orchestra, viola part, bars 96-103'

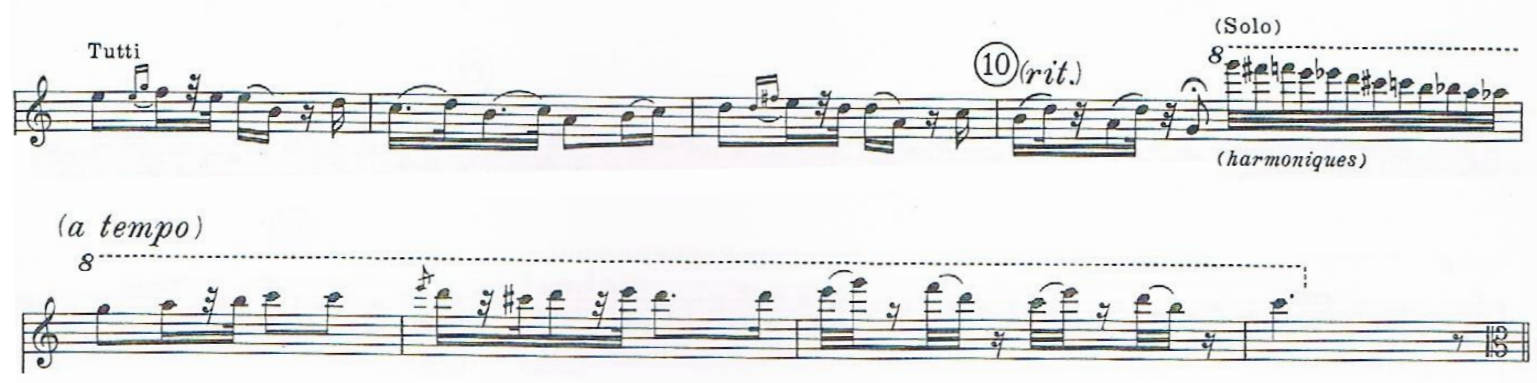

From the examples provided in the discussion above, it is evident that all the usual demanding techniques associated with Paganini's violin music are present in his Sonata per la Grand'Viola, including double stops, fast runs, high positions and harmonics. From the selection of technical elements used by Paganini in this Sonata, one can infer that Paganini did not consider the viola to be an instrument that was significantly less capable of performing virtuoso techniques than the violin. There is only one key exception, however: the size of the instrument clearly did prevent Paganini from using one of his favourite techniques - tenth as an interval, and as double stopping in tenth.

It seems most likely that Paganini's interest in the viola was initiated by the bigger size of the instrument, which potentially can produce a bigger sound. The violin, with its small body size, was originally designed for more intimate settings rather than for the large

\footnotetext{
${ }^{19}$ Nicolò Paganini, Le Streghe. Introduzione, Tema con Variazioni e Finale, Opus. 8 (1813), edited by Tibor Ney (Budapest: Editio Musica, 1968).
} 
concert halls that became an increasingly common feature in the nineteenth century, and that drew larger crowds; a factor that was key to making money as a virtuoso. Perhaps in the battle against growing competition from the piano - an instrument with a louder sound and richer texture - Paganini turned to the viola as a possible substitute for the violin. In the long run, however, the viola's lack of brilliance in the sound and its limitations when adopting virtuoso techniques due to the bigger fingerboard, made his interest in this instrument reasonably short-lived.

Nevertheless, Paganini proved that the viola can and, indeed, should be considered a virtuoso instrument. His Sonata per la Grand' Viola inspired many other composers and performers to explore the viola's 'concealed' virtuosic qualities. Arguably, the celebrated Scottish violist William Primrose was one of the first pioneers who not only undertook the challenge of performing Paganini's original compositions for the viola, but also transcribed some of the composer's most popular pieces from violin repertoire for the viola, including a selection from the 24 Caprices, op. 1 and La Campanella, the third movement of his Violin Concerto in B minor, op. 7 (1924).

\section{Ib. William Primrose and his Arrangements}

The controversy that has arisen over transcriptions of so-called 'non-viola' repertoire for the viola - that is, mainly rearranged music taken from the violin repertoire - is of interest to both performing artists and audiences alike. Many professional violists not only include existing arrangements of the violin repertoire in their recitals and recordings, but also actively seek out music for other instruments that is new (to them) and make their own transcriptions.

And yet, as prevalent as the practice of borrowing from the violin literature is, and, perhaps, as necessary as it is given the dearth of original virtuoso viola repertoire, nevertheless critics very often criticise heavily those violists who dare to perform virtuoso pieces transcribed from the violin repertoire ${ }^{20}$. There are, of course, a few issues

\footnotetext{
${ }^{20}$ One of many examples of such critique is Paul Doctor's well-published opinion that '...the fact must not be neglected that the viola is primarily an expressive instrument. The desire to imitate the virtuoso style of the violin should be avoided.' In Samuel and Sada Applebaum, The Way They Play. Illustrated Discussions With Famous Artists and Teachers. Book 1 (Neptune City, N.J., 1972), Paul Doctor p.222.
} 
concerning the compatibility of virtuoso violin music with the original qualities of the viola not least (as mentioned above) the significantly larger size of the instrument itself.

Rather surprisingly, a further issue can be identified, one which arose from the feedback on one of my own recent performances. The recital in question included five of the Paganini caprices transcribed for the viola, and in discussion afterwards one member of the audience described her experience of listening to those works played on the viola as 'weird'. After initially trying to identify faults in my performance in an attempt to find an explanation for such a description, while reading David Dalton's Playing the Viola.

Conversations with William Primrose recently, I found a possible explanation. ${ }^{21}$

Referring to Bach's Chaconne in D minor (from Partita No. 2, BWV 1004), Primrose said, 'Having absolute pitch, it disturbs me to hear the Chaconne in D minor, for example, played in G minor. ${ }^{22}$ Perhaps, given that most of violin transcriptions for the viola are transposed down a fifth, is it possible that the shift in register creates a jarring effect for some audience members, even if they do not have perfect pitch? It is particularly telling that a man who was arguably the principal enthusiast of virtuoso transcriptions of the time, made this comment. William Primrose (1904-82) carried through the ideas developed earlier by Lionel Tertis (1876-1975), a violist who dedicated his life-long career to promoting and teaching the viola. Significantly, however, there is a major difference between Tertis's and Primrose's approach to the viola as a solo instrument.

Yehudi Menuhin (1916-99) provided a precise description of their unique positions in the world of viola pedagogy and performance, remarking: 'If Lionel Tertis was the first protagonist, Primrose was certainly the first star of the viola. ${ }^{, 23}$ Tertis was also responsible for creating a large number of wide-ranging arrangements for the viola, which are known, above all, for their concentration on the intrinsic qualities of the viola as a solo instrument, in particular its deep tone and sombre sound.

It is worth noting, however, that the nature of Tertis' arrangements was influenced by the type of instrument they were written for: Tertis was performing on and promoting a large viola, the so-called 'Tertis-Richardson Model' with a back measuring 163/4 inches

\footnotetext{
${ }^{21}$ David Dalton, Playing the Viola. Conversations with William Primrose (New York: Oxford University Press, 1988), Chapter 13, The Repertoire, p.186.

${ }^{22}$ David Dalton, Playing the Viola, p.186.
} 
(roughly $43 \mathrm{~cm}$ ) in length. ${ }^{24}$ Unlike Tertis, Primrose chose to play on a smaller instrument, as he explained in conversation with David Dalton:

Tertis appeared to favour the sonority and modelling of violas after Gaspar de Saló prototypes, where I favour the standard set by Stradivarius and Andreas Guarnerius. I am inclined to enjoy the mezzo-soprano rather the contralto quality in the sound of violas - which he preferred ... if I understand correctly, the ... larger violas were often employed in doubling voices, and not virtuoso performance. ${ }^{25}$

It is evident that Primrose's ability and desire to perform virtuoso pieces, including transcriptions from the violin repertoire, were behind his choice of instrument size. His allconsuming interest in the virtuoso repertoire undoubtedly lay in his early experiences as a violin student, both in terms of the development of his technical abilities and musical influences. In fact, Primrose attributed his 'very adequately developed left hand' to the efforts of his first violin teacher, Camillo Ritter, and referred to Eugène Ysaÿe (1858-1931) as a 'soaring musical influence.' 26

It was this specific musical upbringing and interest in virtuoso repertoire that inspired Primrose to transcribe popular pieces from the non-viola repertoire, and also to experiment with different musical styles. He justified his arrangements in his book Walk on the North Side, admitting: 'when it comes to composing I haven't an original idea in my head . . . but I can have a lot of fun with other people's ideas. ${ }^{27}$

Looking back on their first meeting in Paris, in 1928, when Tertis and Primrose performed Mozart's Sinfonia Concertante for Violin and Viola (K364) together, Tertis

\footnotetext{
${ }^{24}$ Samuel and Sada Applebaum, The Way They Play. Illustrated Discussions with Famous Artists and Teachers, Book 1 (Neptune City, N.J.: Paganiniana Publications, 1972), Lionel Tertis, 262-4.

${ }^{25}$ Dalton, Playing the Viola, Conversations with William Primrose, p.10.

${ }^{26}$ Dalton, Playing the Viola, Conversations with William Primrose., p.14.

${ }^{27}$ William Primrose, Walk on the North Side. Memories of a Violist. (Provo, Utah: Brigham Young University Press, 1978), Legacy 192.
} 
described Primrose as a 'most brilliant violinist. ${ }^{28,29}$ Being a concert violinist, Primrose was of course familiar with the virtuoso violin repertoire. Primrose admitted that after transferring from violin to viola he felt that he had given up 'the joys of transcendental technical display more characteristic of violin music,' but pointed out 'there are so many compensations. $^{30}$

\section{Paganini's La Campanella}

Primrose transcribed some of the popular virtuoso pieces from the violin repertoire for the viola. One of the most appreciated and well known is La Campanella, the third movement, Rondo, of Paganini's Violin Concerto in B minor, op. 7 transcribed for the viola and piano. The range of the brilliant virtuoso techniques used in this arrangement is extremely impressive, even though Primrose simplified some of the technically-demanding elements of the original version. As I will outline below, it is clear from this piece why Primrose was often referred to as the 'Paganini of the Viola'.

Primrose's version of La Campanella for the viola is written in the key of E minor - a fifth down from the piece's original key of B minor. It is shorter than the violin version, since Primrose excluded the Trio section from his arrangement and balanced the piece structurally by adding a lengthy piano solo section immediately after the introduction, which is an exact repetition of the violin part from the opening.

Fritz Kreisler (1875-1962) also made his own arrangement of La Campanella, for violin and piano, and there is an undeniable similarity between his and Primrose's transcriptions of this piece. In fact, structurally, Primrose's version of La Campanella is almost identical to Kreisler's. These two transcriptions differ only in the minor adjustments of some passages and through the addition of double stops made by Primrose. The most significant discrepancy occurs in the coda, where Primrose delegates the arpeggiato runs from the piano part to the viola, rather than assigning it the long trill as Kreisler's version does.

\footnotetext{
${ }^{28}$ Tully Potter. 'William Primrose and his violas', available from http://tarisio.com/cozio-archive/cozio-carteggio/william-primrose-and-his-instruments (accessed 26 January 2016).

${ }^{29}$ Lionel Tertis, My Viola and I. (London: Paul Elek, 1975), Chapter13, Return to the Concert Platform-and America, p.101.

${ }^{30}$ Dalton, Playing the Viola, p. 183.
} 
Otherwise, it is easy to imagine that Kreisler's performances of his transcription of $L a$ Campanella inspired Primrose to make his own arrangement of this piece.

In adjusting the solo part of the original version of this work for the viola, Primrose avoided techniques such as an extensive use of harmonics and extreme finger extensions, which are unsuitable for the viola. He also simplified the double stops of the original version, and masterfully utilised the entire range of the viola without overusing high positions. Nevertheless, Primrose did successfully adapt this piece - one of the most demanding pieces from violin repertoire - for the viola, as the comparison of the original composition with his arrangement that follows demonstrates.

The main adjustment made by Primrose in La Campanella's theme is the omission of grace notes. It is certainly easier to produce a concentrated and short sound on the viola without grace notes and, in fact, if played in the right character, the absence of grace notes does not undermine the musical value of this theme. There is, however, no real technical reason behind the removal of the grace notes as they are perfectly playable on the viola. It seems most likely that their elimination was simply Primrose's aesthetic choice as arranger (see Mus. exs. 13a and 13b).

Mus. ex. 13a. Paganini, arr. Primrose, La Campanella for Viola and Piano, viola part, bars 1$4 .^{31}$

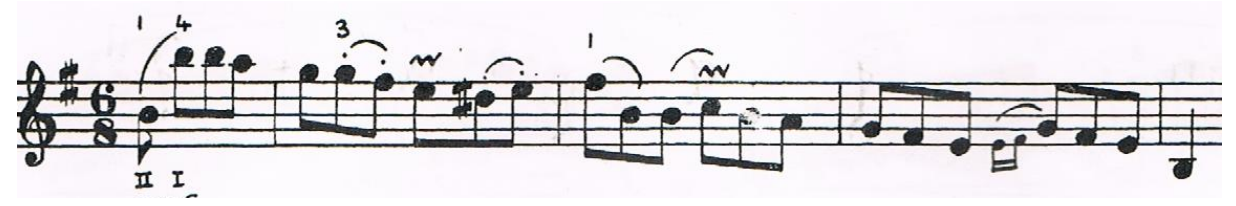

Mus. ex. 13b. Paganini, Violin Concerto in B minor, op. 7, movement 3, 'La Campanella', violin part, bars $1-4 .^{32}$

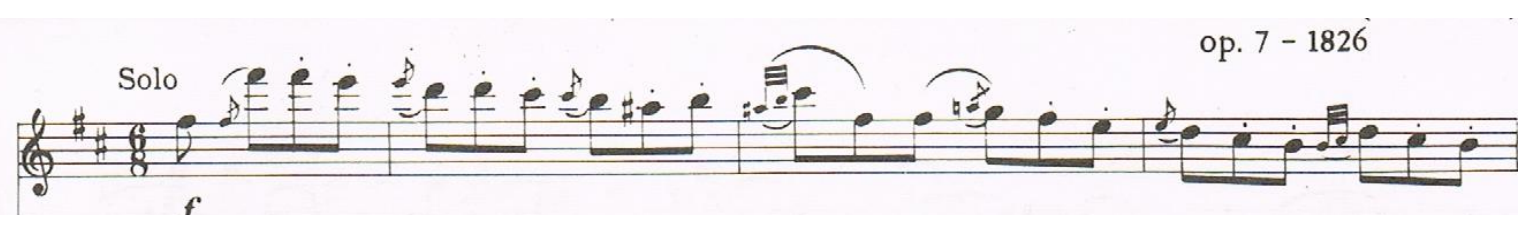

\footnotetext{
${ }^{31}$ All musical examples from this work are taken from Schott's edition: Nicolò Paganini, La Campanella arr. William Primrose, viola and piano (London: Schott \&Co.,1952).

${ }^{32}$ All musical examples from this work are taken from Ney Tibor's edition: Nicolò Paganini, Violin Concerto in $B$ minor, op. 7, violin and piano reduction (Budapest, Hungary: Editio Musica,1968).
} 
In the introduction, Primrose avoided the use of high positions by replacing the ordinary notes with harmonics (see Mus. ex. 14a and 14b). He also replaced the use of harmonics in different octaves, choosing instead to remain in the same position (see Mus. ex. 15a and 15b). The adjustment of this particular technique makes it reasonably easy to execute on the viola, but musically it becomes less engaging than the original violin version due to the fact that the same note is repeated within two subsequent bars. Interestingly, close listening to Primrose's recording of La Campanella (1929) reveals that he uses lefthand pizzicato to vary this motif (see Mus. ex. 15c, in which notes marked with the red crosses were played by Primrose using left-hand pizzicato one octave lower than the harmonics). ${ }^{33}$

Mus. ex. 14a. Paganini, arr. Primrose, La Campanella for Viola and Piano, viola part, bars 2629.

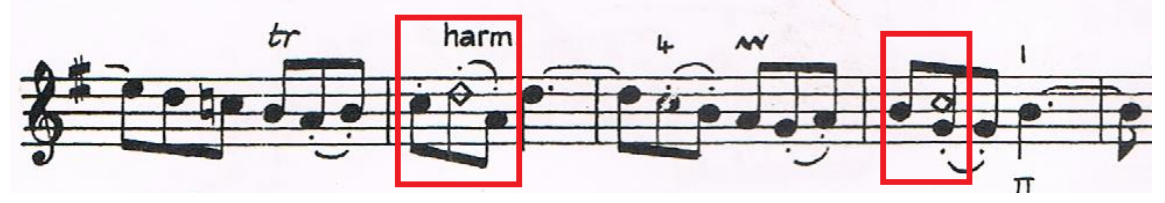

Mus. ex. 14b. Paganini, Violin Concerto in B minor, op. 7, movement 3, 'La Campanella', violin part, bars $26-28$.

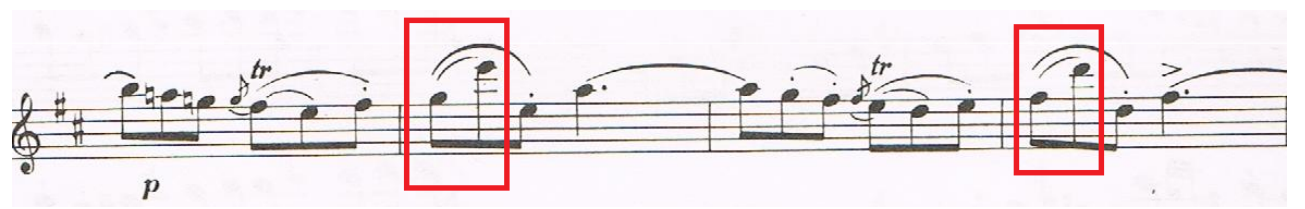

Mus. ex. 15a. Paganini, arr. Primrose, La Campanella for Viola and Piano, viola part, bars 3235.

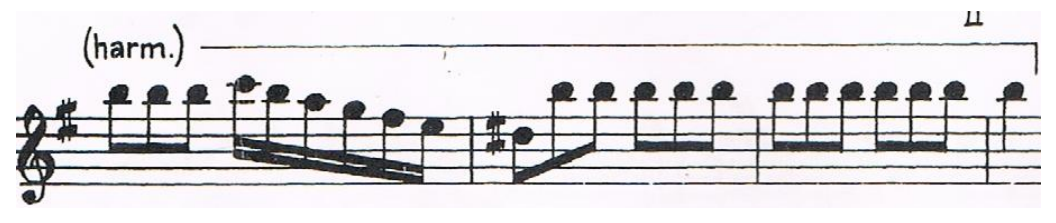

33 'William Primrose plays Paganini's "La Campanella",' undated, available from http://www.youtube.com/watch?v=orx6EstWsl8 (accessed 20 January 2016). 
Mus. ex. 15b. Paganini, Violin Concerto in B minor, op. 7, movement 3, 'La Campanella', violin part, bars 32-34.

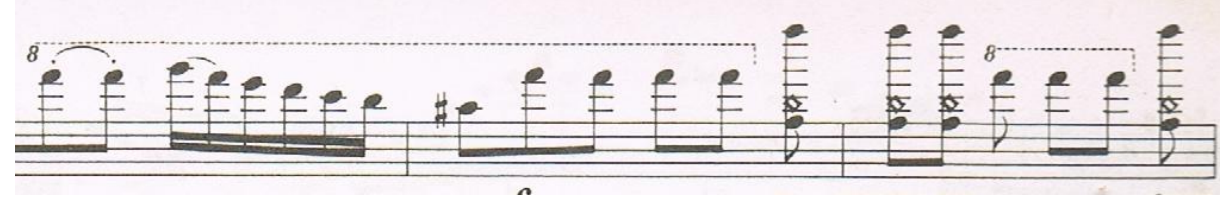

Mus. ex. 15c. Paganini, arr. Primrose, La Campanella for Viola and Piano, viola part, bars 3235.

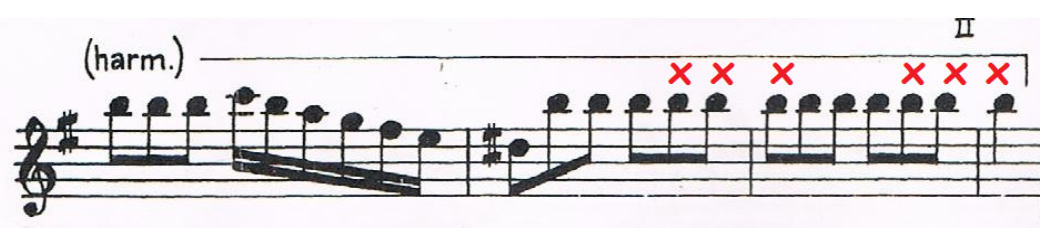

Simplified double stops allow the performer to keep close to the original tempo. Primrose replaced some double stops with ordinary notes and used open string pedals to create double stops. He also extended the length of the measure in the middle of this section by one quaver (see Mus. ex. 16a and 16b).

Mus. ex. 16a. Paganini, arr. Primrose, La Campanella for Viola and Piano, viola part, bar 109.

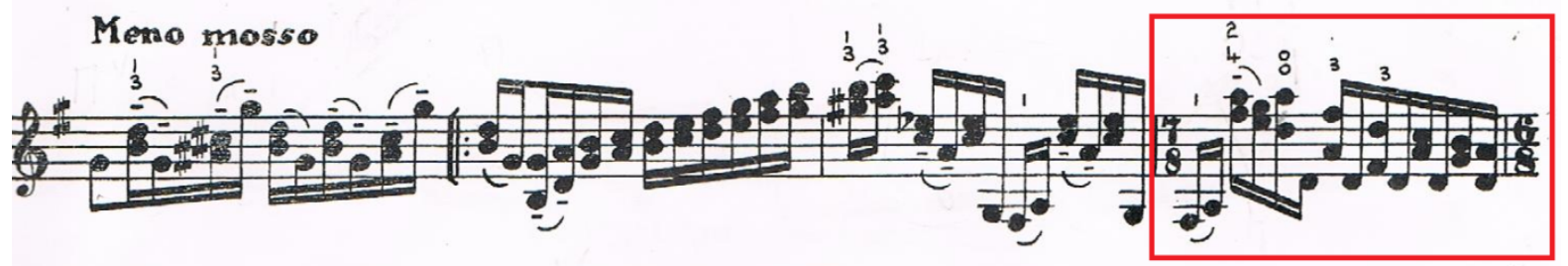

Mus. ex.16b. Paganini, Violin Concerto in B minor, op. 7, movement 3, 'La Campanella', violin part, bar 94 .

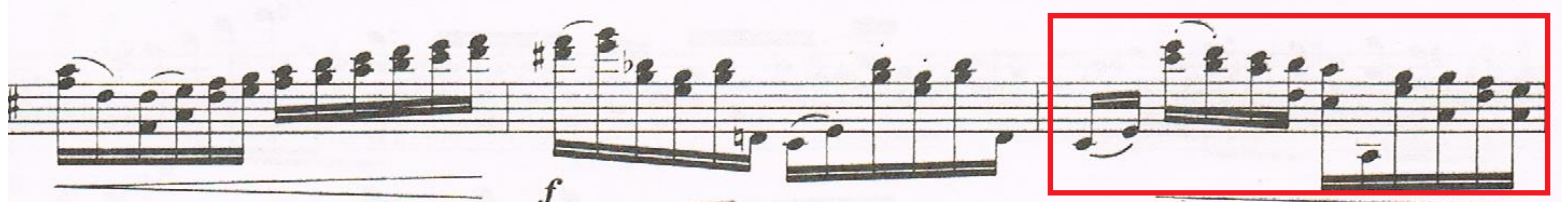


In addition, Primrose inserted a short cadenza before the recapitulation and re-used the theme from the trio in the coda.

Thus, Primrose's version of La Campanella makes numerous modifications, including simplified double stops, the removal of extreme finger extensions and the omission of grace notes, and, in doing so, his arrangement is well adjusted to the intrinsic qualities of the viola and highlights the virtuoso potential of the instrument. The techniques used by Primrose are highly demanding, but still remain playable on the viola.

\section{Arthur Benjamin's Jamaican Rumba}

One further raison d'être for Primrose's transcriptions was his own well-known professional jealousy towards his colleagues - including towards virtuoso violinists, violoncellists with their luscious sound, singers and even a string quartet - since, in his words, 'there were those [transcriptions] which were fashioned out of envy'. ${ }^{34}$ One example of this is the transcription he made of Heitor Villa-Lobos's Aria (Cantilena) from Bachianas Brasileiras No. 5 for viola and piano, in 1947. In conversations with David Dalton, Primrose described the inspiration behind this arrangement: 'I envied Miss Bidú Sayão in that wondrous long line of melody with which she astonished us all at the time in the Bachianas Brasileiras No. 5 of Villa-Lobos, and I had a great deal of fun fitting eight cellos into two hands on the piano., ${ }^{35}$

In this transcription, Primrose indulged his fascination with the mezzo-soprano timbre of the viola. He employs high positions on the two lower strings of the viola extensively, using $C$ and $G$ strings from the beginning until the piece's middle section (Piú mosso). Only in the recapitulation does Primrose transport the theme to the high register on D and A strings. While not very demanding technically, this arrangement highlights the sombre and sonorous sound of the viola in the exposition and recapitulation. Perhaps not surprisingly, not least given the widespread acclaim of the original work, Primrose's transcription has achieved great popularity in the viola repertoire.

Throughout his career, Primrose participated in chamber music ensembles led by virtuoso violinists such as Jascha Heifetz (1901-87), Fritz Kreisler and Mischa Elman (18911967). These experiences impressed on Primrose the desire for a virtuoso repertoire for his

\footnotetext{
${ }^{34}$ Dalton, Playing the Viola, Conversations with William Primrose, p.184.

${ }^{35}$ Dalton, Playing the Viola, Conversations with William Primrose, p.184.
} 
own instrument: 'They [Heifetz, et al] . . . weren't my direct teachers, and yet I learned powerfully from them ... ${ }^{36}$

Heifetz and Primrose first met at the opening of Mexico City's new opera house - the Palacio de Bellas Artes - in 1935. Primrose recalls his first impression of the violinist: 'Heifetz soon had us rolling on the floor with his remarkable imitation of perfectly bad fiddle playing. I realised then that to play perfectly badly one had to be a perfectly marvellous fiddle player. ${ }^{\prime 37}$ Some twenty years later, in the mid-1950s, Heifetz, Primrose and the violoncellist Gregor Piatigorsky (1903-76) formed what would become a famous trio that made many wonderful recordings over the course of the next six years.

In his memoirs, Primrose later recalled that Heifetz was never disrespectful of his colleagues' opinions, worked very hard and had an extraordinary sense of rhythm. He also described his relationship with Heifetz as 'a congenial comradeship' and noted that he always treated the great violinist with [the] greatest respect. ${ }^{38}$ Unfortunately, Heifetz did not approve of Primrose's transfer to Indiana University from the University of Southern California - where Primrose, Piatigorsky and Heifetz taught together and where a special division had been created for their trio in the mid-fifties. Gradually, all contact between Primrose and Heifetz ceased. After the death of Heifetz, Primrose wrote: 'The broken circuit of my association of more than thirty years has ever grieved me, and continues to grieve me. ${ }^{39}$

There can be no doubt that this unique relationship, and the experience of witnessing Heifetz's virtuoso practice at first hand over a period of some years, made a marked impact on Primrose's own work. In 1944, he transcribed Arthur Benjamin's Jamaican Rumba (from the composer's orchestral suite, Two Jamaican Pieces, 1938) for violin and piano, and dedicated it to Heifetz. A decade later, in 1954, Primrose published a viola version of this piece, which is a clear reflection of the effortless virtuosity of Heifetz, demanding as it does from the violist the light touch of the virtuoso violinist.

Jamaican Rumba comprises two contrasting themes: one labelled Tempo giusto - alla rumba, and the other cantabile. The former is light and full of syncopated rhythms

\footnotetext{
${ }^{36}$ Dalton, Playing the Viola, Conversations with William Primrose , p.14.

${ }^{37}$ William Primrose, 'Heifetz,' in Heifetz, 3rd rev. edn., ed. Herbert R. Axelr (Neptune City, NJ: Paganiniana Publications 1990) p.577.

${ }^{38}$ William Primrose, 'Heifetz,' pp.577-595.

${ }^{39}$ William Primrose, 'Heifetz,' p.594.
} 
characteristic of the rumba (see Mus. ex. 17). The use of the high register, a piano dynamic and light spiccato bow strokes can all easily mislead a listener, as the viola imitates a violin very closely in this theme. Primrose is expanding the musical material of this motif by using a variety of virtuoso techniques: ascending chromatic scales of double stops in sixth, broken fourths, descending scales of double stops in thirds, and flying staccato bow strokes.

Mus. ex. 17. Benjamin, arr. Primrose, Jamaican Rumba for viola and piano, viola part, bars 9$13 .^{40}$

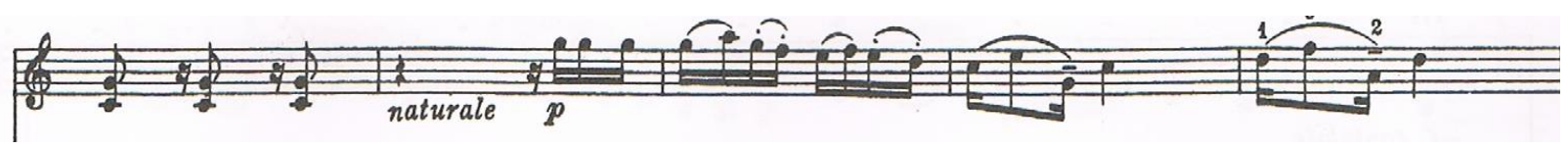

The second theme - the cantabile - is repeated in the recapitulation one octave higher (see Mus ex. 18)

Mus. ex. 18. Benjamin, arr. Primrose, Jamaican Rumba for viola and piano, viola part, bars 27-30.

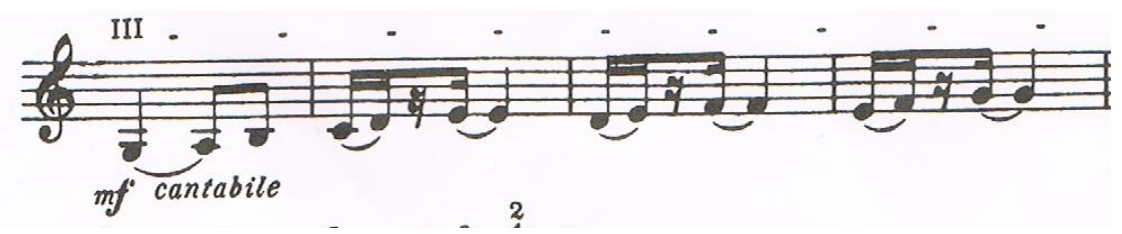

A comparison of the two versions reveals that only a few minor adjustments were made by Primrose for the viola. They mainly affect material in high positions that is not suited to the viola, and solve the problem by transposing the viola part down an octave (see Mus. exs. 19a and 19b).

${ }^{40}$ All musical examples from this work are taken from Boosey \& Co., Ltd.'s edition: Arthur Benjamin, Jamaican Rumba, arr. William Primrose, viola and piano (New York: Boosey \& Hawkes Co., 1954). 
Mus. ex. 19a. Benjamin, arr. Primrose, Jamaican Rumba for violin and piano, violin part, bars $17-26 .^{41}$

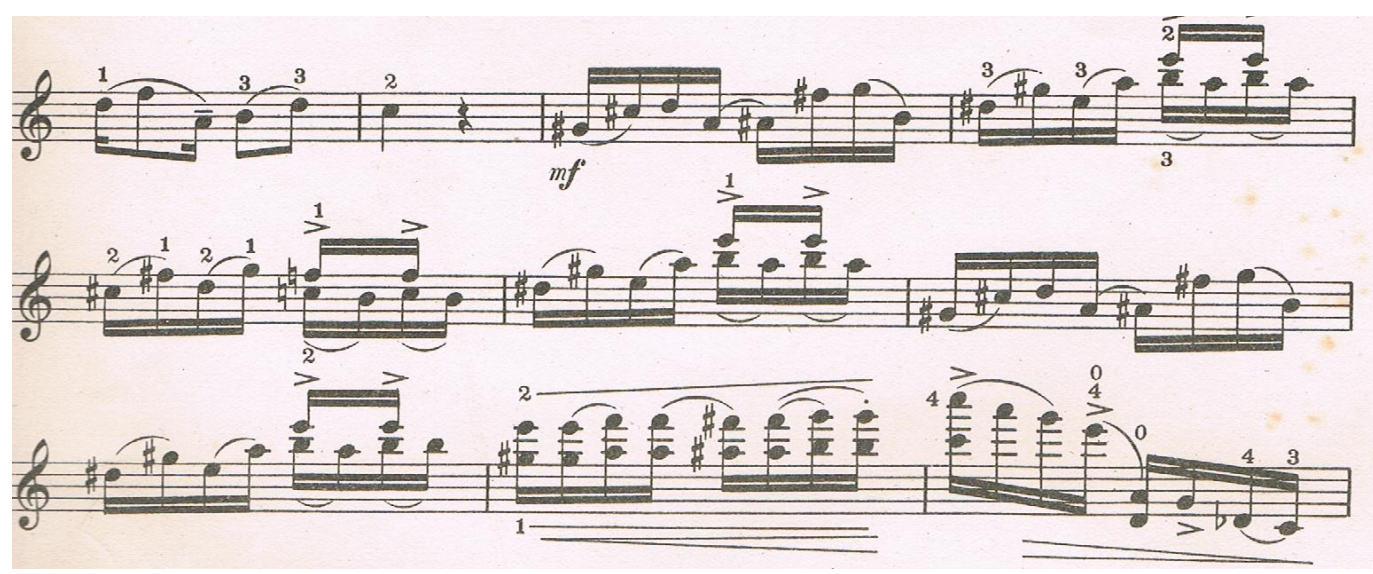

Mus. ex. 19b. Benjamin, arr. Primrose, Jamaican Rumba for viola and piano, viola part, bars 17-26.
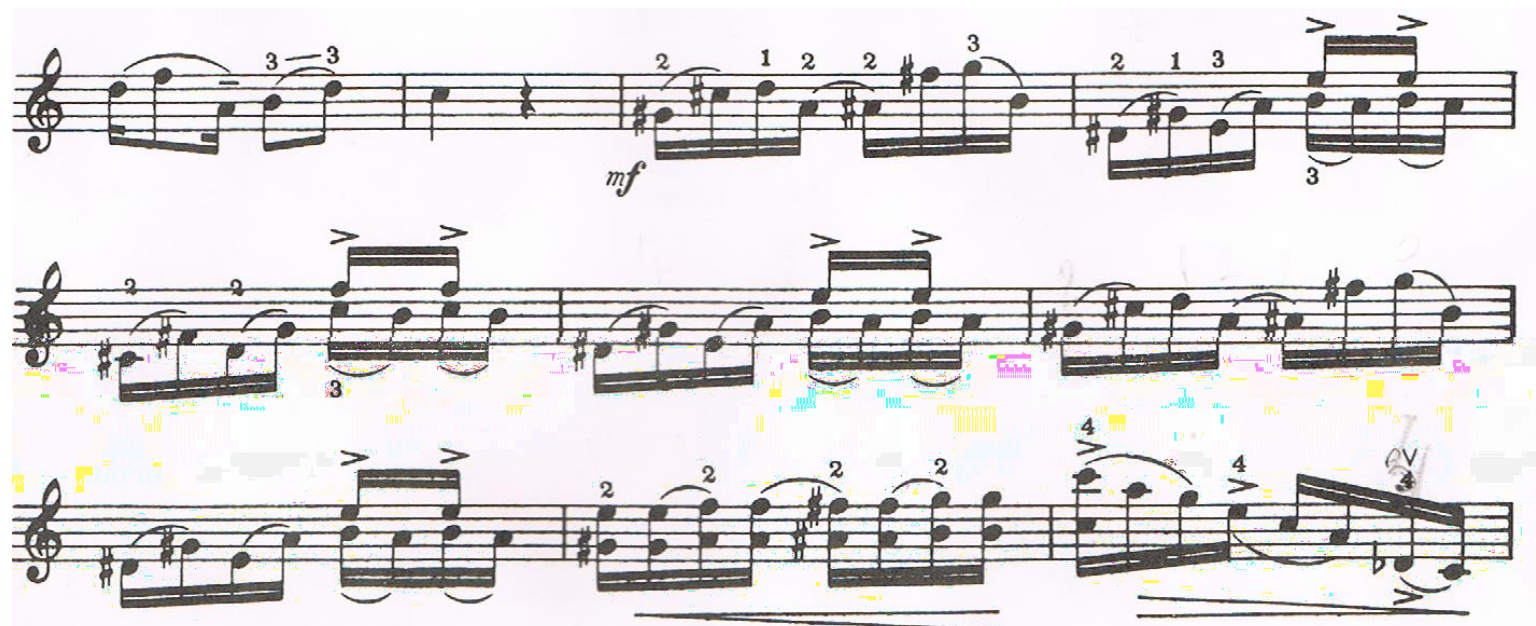

Despite the transposition to the lower register, the techniques used in the viola arrangement are otherwise identical to those Primrose employed in his violin version. Only once does he simplify the double stops, exchanging tenths to thirds; however, he offers the same option in the violin reduction (see Mus. exs. 20a and 20b).

\footnotetext{
${ }^{41}$ All musical examples from this work are taken from Boosey \& Co., Ltd.'s edition: Arthur Benjamin, Jamaican Rumba, arr. William Primrose, violin and piano (London: Boosey \& Hawkes, Ltd., 1944)
} 
Mus. ex. 20a. Benjamin, arr. Primrose, Jamaican Rumba for violin and piano, violin part, bars 41-43.

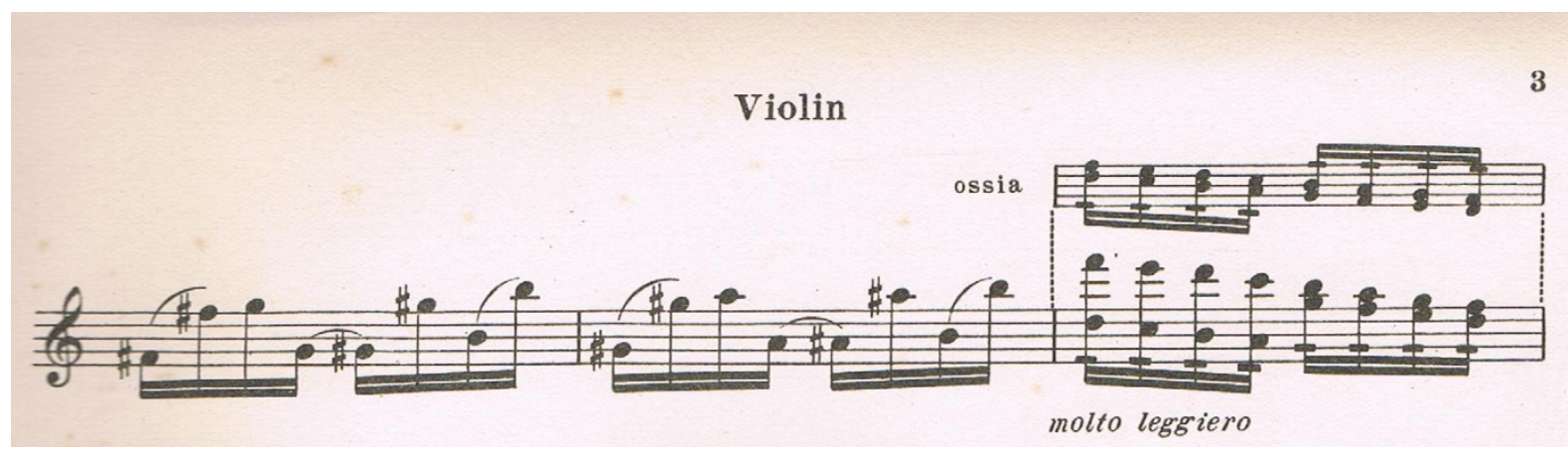

Mus. ex. 20b. Benjamin, arr. Primrose, Jamaican Rumba for viola and piano, viola part, bars 41-43.

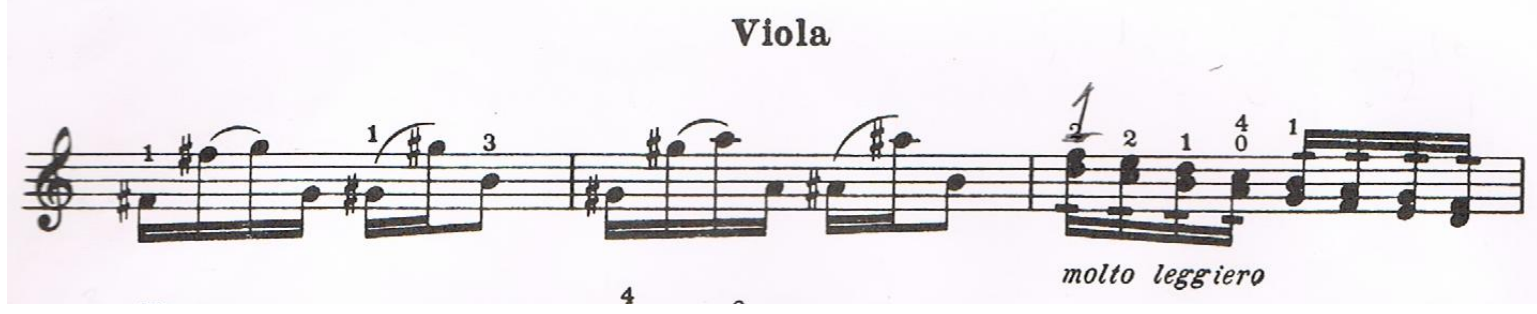

All in all, this is a delightful arrangement of an original piece that is well suited for the viola. Not only does it highlight the lilting sound of the instrument in the cantabile section, but also it displays beautifully the virtuoso potential of the instrument in the Tempo giústo section that precedes it.

\section{Paganini's Caprices, op. 1}

A discussion of Primrose's transcriptions would not be complete without mentioning his arrangements for viola of Paganini's Caprices, op. 1 and his own performances of those works. Talking with David Dalton about his arrangements and inspirations behind them, Primrose remarked: ‘ . . s sheer contumelious, roister-doister bravado took over when it 
came to transcriptions and, need I add, performances of the Caprices of Paganini! I aimed to épater les bourgeois and set the cat among the pigeons in the violists of the day. ${ }^{, 42}$

Interestingly, not all violists supported Primrose's enthusiastic approach to Paganini's Caprices. The renowned American violist Paul Doktor (1917-89) was, in particular, very sceptical about the value of these arrangements within the viola repertoire, commenting: 'They [the Paganini caprices] are perfectly fine as technique builders and of course they are unexcelled for show off pieces but with works like that we forget the genuine sound quality of the viola. And if these works for the viola become too popular, we may not have genuine viola art. $^{43}$

When considering seriously such a strong statement from a professional performersomeone whose own arrangements for the viola enriched the instrument's concert repertoire and remain popular today, it is important to address a number of questions. Can a performer potentially benefit from 'going the extra mile' and stretching his/her physical abilities by practising and performing Paganini caprices? How suitable are transcriptions of Paganini caprices for viola? And, finally, how should the caprices be approached so as to not to underestimate the 'genuine viola art'? ${ }^{44}$

When viewing the available videos of Primrose's performances of the caprices, it becomes apparent that there is no question regarding the suitability of these pieces for viola. In Primrose's hands they sound beautiful and look playable, which is perhaps the reason for the reaction of Mischa Elman (as described by Primrose in his conversations with David Dalton): ' . . I I whirled through Paganini No. 5, and after a moment's cogitation he [Elman] exclaimed, "It must be much easier on the viola".,45

Primrose's position was very clear: 'If the violist has the technique to perform those flabbergastings, let him go to it.' Indeed, according to his own modus operandi, Primrose was always guided in his transcriptions ' $\ldots$ by how well the piece would sound on the

\footnotetext{
${ }^{42}$ Dalton, Playing the Viola, Conversations with William Primrose. p.184.

${ }^{43}$ Samuel and Sada Applebaum, The Way They Play, p.222.

${ }^{44}$ Paul Doktor did not elaborated on what is his understanding of the 'genuine viola art' but his another description of the viola gives an explanation of this say: "...the fact must not be neglected that the viola is primarily an expressive instrument. The desire to imitate the virtuoso style of the violin should be avoided", in Samuel and Sada Applebaum, The Way They Play, Paul Doktor, p.222.

45,44 Dalton, Playing the Viola, Conversations with William Primrose. p.185.
} 
viola. ${ }^{46}$ Through my own experiences of performing these works, I can concur that Primrose's transcriptions are thoughtfully adjusted to suit the unique qualities of the viola, and are generally very well received by the audience.

Primrose arranged for viola only four of Paganini's 24 Caprices: numbers 5 and 13 for solo viola, and numbers 17 and 24 for viola and piano. It is not clear whether he considered the other twenty caprices unsuitable for viola or whether he simply transcribed only his favourite pieces. Interestingly, Primrose very often played his transcriptions down a fifth, using violin sheet music, so perhaps he chose those pieces that in his opinion sounded better on the viola.

Unfortunately, many of Primrose's transcriptions were never published and, being unable to find a printed version of Primrose's transcriptions of Paganini Caprices in time for my recitals, I chose instead to use a version of the caprices transcribed for viola by Léon Raby, a decision based on its similarities with my favourite violin editions by Ruggiero Ricci. Surprisingly few versions of the Paganini caprices exist for the viola, whereas the picture is very different in the world of violin music. Many great soloists, including Ruggiero Ricci and Carl Flesch, made their own edition of Paganini's Caprices. I also consulted the facsimile edition of the original edition of Paganini's op. 1 (published by Ricordi in 1820).

The analysis that follows compares the facsimile of the 1820 publication with Ruggiero Ricci's edition of the Paganini Caprices (the latter being one of the most popular amongst contemporary performers) with Raby's transcription for viola, together with the available videos of Primrose's performances of a selection of the caprices.

Without a doubt, the most popular of the 24 Caprices is the final one: No. 24 in A minor, Tema con Variazioni (Quasi Presto). The original theme of this caprice inspired many composers, who borrowed it to use in their compositions (see Mus. ex. 21). There is no significant difference between the facsimile and Ricci's edition, except the bowing. Ricci indicates the same bow direction for the first two notes and in the facsimile these notes are separated (see Mus. ex. 22). Raby's transcription of this caprice for viola inevitably transposes it a fifth down, and uses the bowing similar to Ricci's transcription. (See Mus. ex. 23). 
Mus. ex. 21. Paganini, 24 Capricci Per Violino solo, op. 1a. Facsimile, No.24 Tema con Variazioni, bars 1-11. ${ }^{47}$

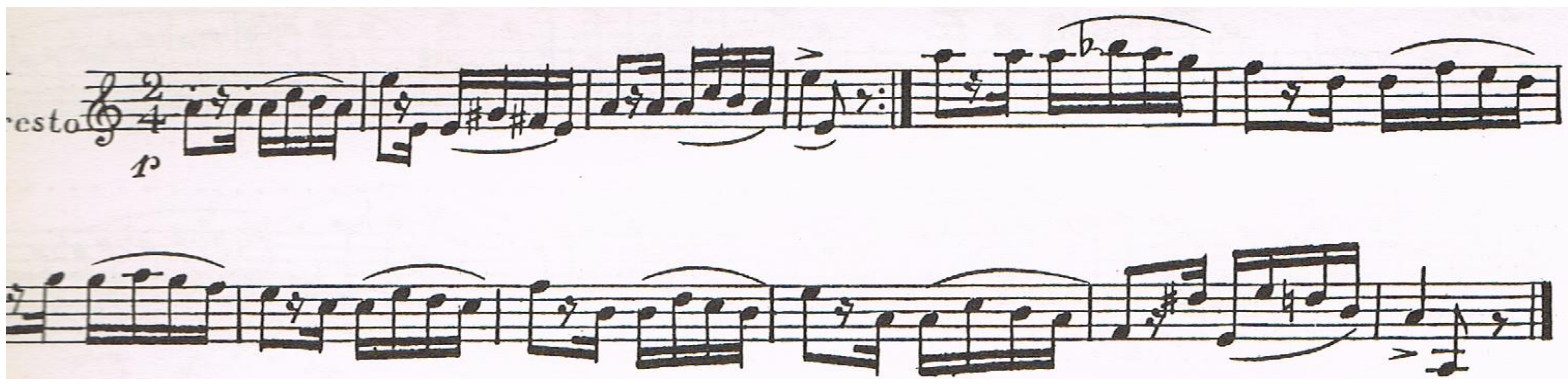

Mus. ex. 22. Paganini, edit. Ricci 24 Capricci per violin solo, op. 1 , No.24 Bars 1-11. ${ }^{48}$

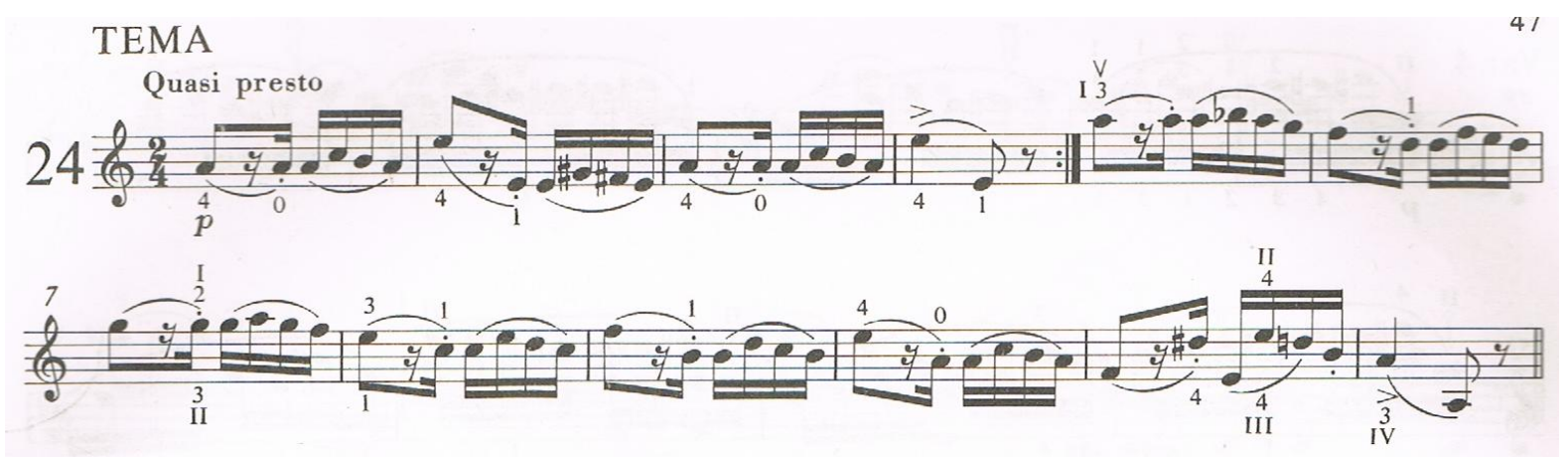

Mus. ex. 23. Paganini, transcribed by L. Raby 24 Caprices, op. 1. No. 24, Viola, bars 1-11. ${ }^{49}$

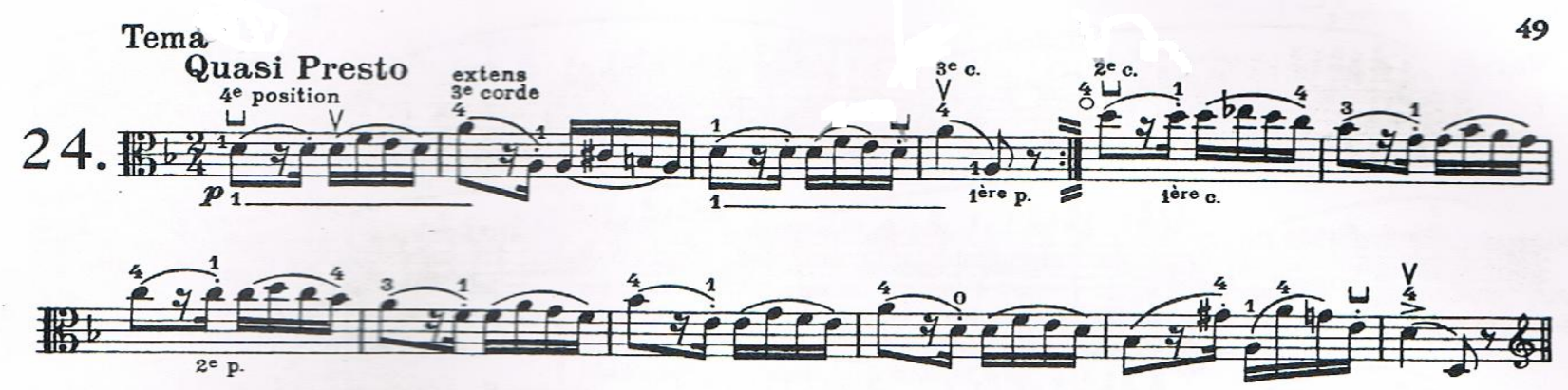

${ }^{47}$ All musical examples from the 24 Caprices are taken from the facsimile edition of the original Ricordi edition (Milan, 1820): Nicolò Paganini, 24 Capricci per violino solo, Performers' Facsimiles, 244 (New York: Broude Brothers, 2002).

${ }^{48}$ All musical examples from this work are taken from Editio Musica's edition: Nicolò Paganini, 24 Capricci per violin solo Op.1, edited by Ruggiero Ricci, (Budapest: Editio Musica, 1984).

${ }^{49}$ All musical examples from this work are taken from Kalmus Classic's edition: Nicolò Paganini, 24 Caprices Op. 1, transcribed L. Raby, Viola (New York: Kalmus, 1985) 
Primrose, in his performances, transports the theme a fifth down but does not make any further changes. In the first four variations, there are not many differences between the facsimile, Ricci's violin version, Raby's viola version and Primrose's interpretation. Each variation displays the virtuoso end of the scale of a particular technique.

Once we get to the fifth variation, more substantial differences begin to emerge. The fifth variation is based on the short motifs of octaves descending and ascending in semitones in the different positions. Often, in the violin version, the optional fingering of the fingered octave is suggested. Unlike Raby, Primrose excluded the fifth variation from his interpretation entirely. I found this variation incredibly difficult to execute. The reason is that the most comfortable and commonly used on violin fingering of combination of the fingered and ordinary octaves, was hardly useful on the viola due to the extreme extension between the $2^{\text {nd }}$ and $4^{\text {th }}$ fingers in fingered octaves, especially in the first position. ${ }^{50}$

Variation six, arguably, is the most challenging for the viola. Two ascending runs of tenth in the semiquavers require exceptional left hand technique. Primrose is shining in the full glory of his virtuosity as a violist in the video recordings available, but even this unexcelled viola virtuoso replaced second passage of tenth on $\mathrm{G}$ and $\mathrm{C}$ strings with passage in thirds on D and A strings. ${ }^{51}$ Raby's version has two passages of tenth.

The next variation, seven, is based on similar techniques to those Paganini used in 'La Campanella': semiquaver triplets creating an obligato of the theme. There is no difference between the Raby's and Ricci's transcriptions, or Primrose's recording

Variation eight is a tune hidden in the chord texture. The only difference between all the aforementioned transcriptions is the bowing. Primrose plays every chord down-bow and in Raby's transcription every two chords are slurred.

Left hand pizzicato is the main technique in the ninth variation, which is particularly difficult to execute on the viola, as the thickness of the strings requires extra muscle power from the little finger. Not all runs work well in the viola version, and some notes marked in the violin part as a left hand pizzicato could be replaced with the bowed notes for the sake of keeping all the notes of the run equally audible. (See Mus. exs. 24a and 24b)

\footnotetext{
${ }^{50}$ William Primrose plays Paganini No.24, undarted, available from https://www.youtube.com/watch?v=hn3RYzDuQcE (accessed 28/04/2014).

${ }^{51}$ Primrose, Walk on the North Side. Memories of a Violist, p.14.
} 
Mus. ex. 24a. Paganini edited by Ruggiero Ricci 24Capricci per violin solo, op. 1, Violin, Var.9, bars 113-120.
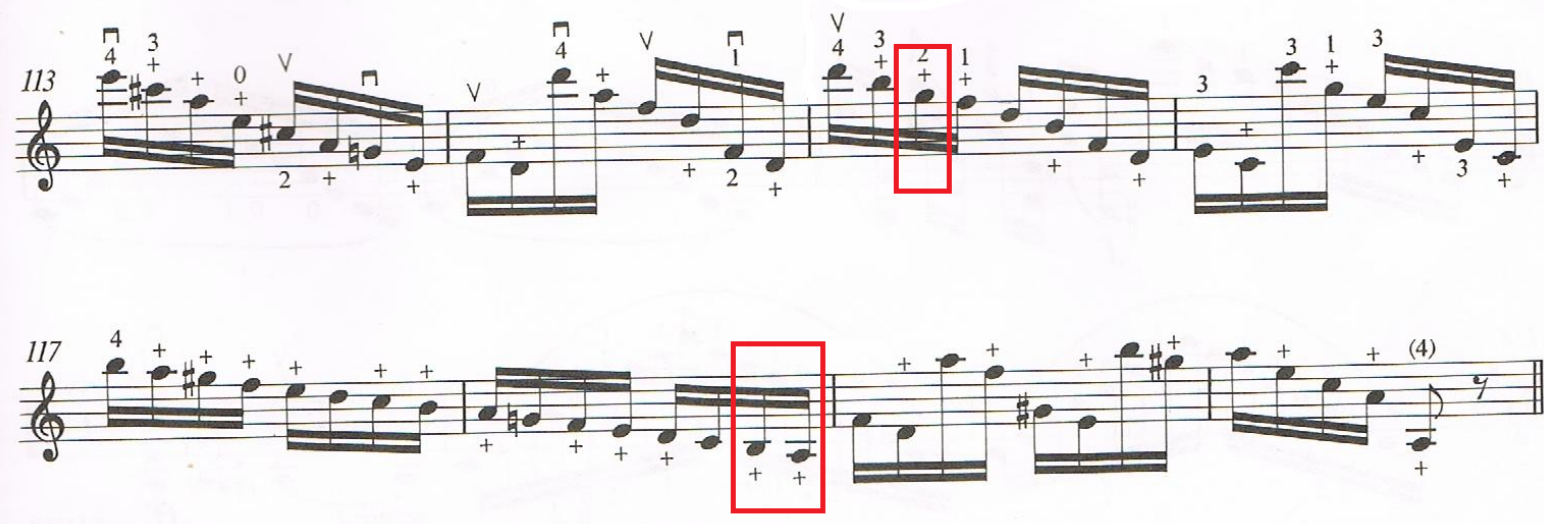

Mus. Ex. 24b. Paganini, transcribed by L. Raby 24 Caprices, op. 1, Viola, No. 24, Var. 9, bars 128-139.

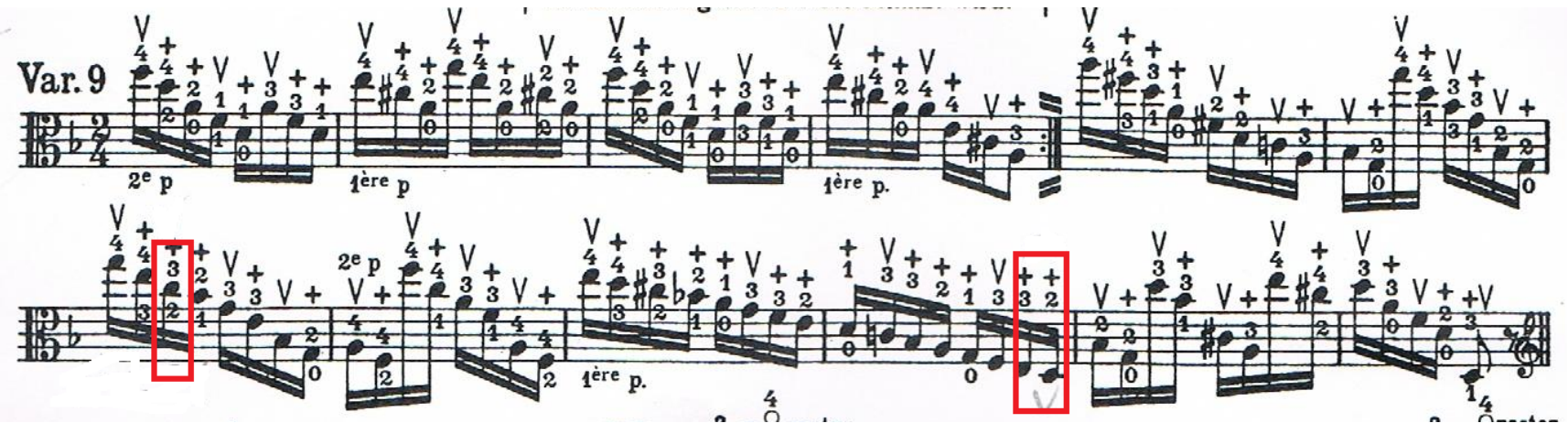

The sound and clarity of the runs would benefit if the notes highlighted in red from the example 11a (viola version) were played with the bow.

Here, in variation ten, Primrose departs most dramatically from the other versions using artistic licence to transform the tenth variation into a gypsy-like melody. Unlike both printed versions (violin and viola), Primrose is playing the entire tune in harmonics. He is improvising at the end of this variation and it is different in the various recordings.

Primrose excludes variation eleven from his version and instead finishes the caprice by returning to the theme, which he varies with chords and arpeggios.

Comparing Raby's and Ricci's versions with Primrose's video and audio recordings of this caprice, I can conclude that Raby's version is very close to Ricci's in respect of the bowing, and is direct transposition to the fifth down from the original violin version. 
Primrose, by excluding some variations from his transcription and replacing tenth with the thirds, made this caprice more suited for the viola.

Primrose and Raby's viola version of Caprice No. 17 is an exact copy of the original, transported to fifth down. This caprice poses a major difficulty for violists in its middle section, which is comprised of double stops in octaves and tenth. Raby's fingering suggestion is the natural octaves. In the violin version, the most common fingering option for the middle section is fingered octaves. (See Mus. exs. 25a and 25b).

Mus. ex. 25a. Paganini, edited by Ruggiero Ricci 24 Capricci per violin solo, op. 1, No. 17, bars 24-26.

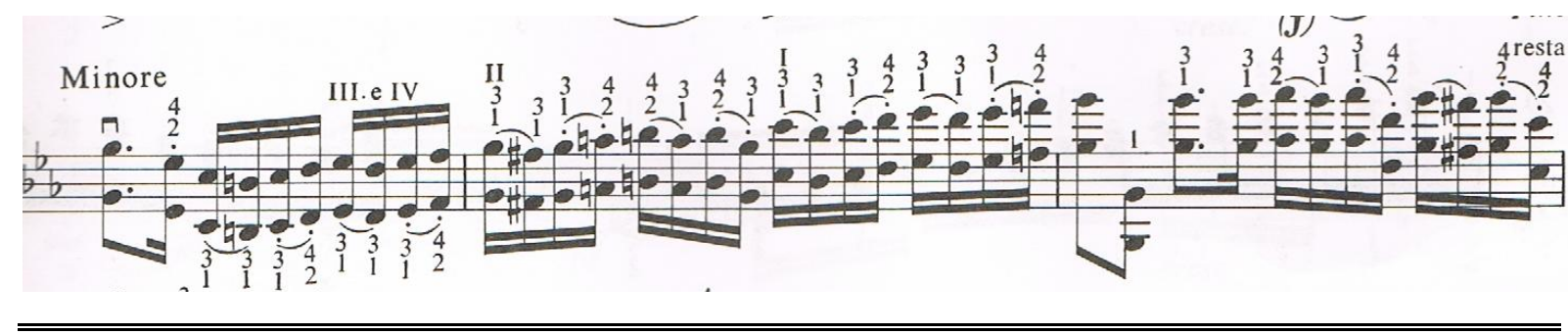

Mus. ex. 25b. Paganini, transcribed for viola by L. Raby 24 Caprices, op. 1, No. 17, bars $24-$ 26.

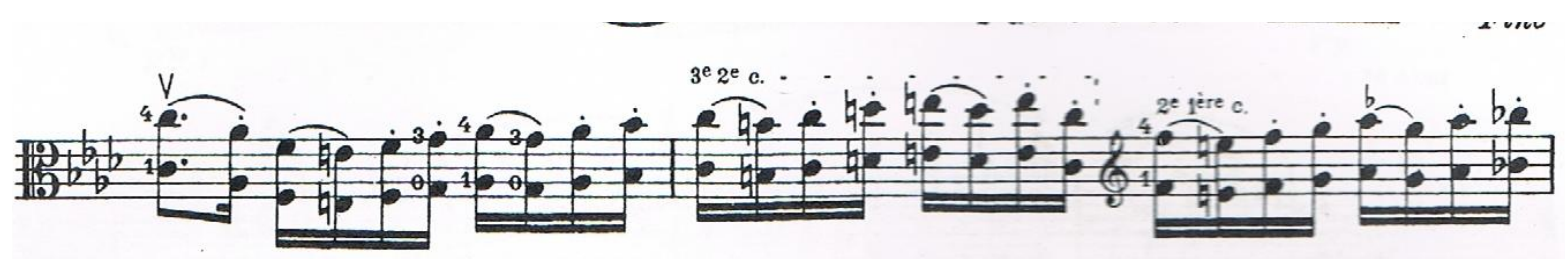

During my own exploration of this caprice, I came to the conclusion that by using fingered octaves the performer gains an advantage in tempo and better intonation. However, for violists with a smaller hand or a larger instrument, the finger extension can be problematic.

In his interpretation, Primrose keeps it close to the original violin version and only once changes a minor chord to a major chord - in the second to last measure of this section. He also transports the last passage even further to the high position starting the run on the $\mathrm{G}$ note instead of $\mathrm{E}$ and plays the last notes of the Caprice pizzicato, not arco. 
Raby did not use the piano accompaniment in his transcriptions of the Paganini Caprices. Primrose uses piano accompaniment for both the $24^{\text {th }}$ and $17^{\text {th }}$ caprices. In the case of the Caprice No. 17, the piano accompaniment does not carry much musical value and is used mainly as a support for the soloist. The piano plays a more important role in the Caprice No. 24 as it is given an introduction, and in some variations the piano takes the solo part in the repeats, instead of the violin. This version is very close to Leopold Auer's transcription of this caprice ${ }^{52}$. In some recordings the piano part is explored even more with the insertion of harmonies reminiscent of the Listz's Etude No.6 (Theme and Variations in A minor based on the Caprice No. 24) from the Grandes études de Paganini. ${ }^{53}$

Primrose transcribed caprice No.13 in B-flat major nicknamed "The Devil's Laughter" for viola solo. The opening section of this caprice is built on the descending chromatic scales comprising thirds. The major technique used for the middle section of this caprice is the broken octaves in descending and ascending chromatic scales. The viola version is an exact copy of the original transported a fifth down. In his performances, Primrose omitted the repetition of the first sentence of the introduction. In the Da Capo, Primrose ignores Paganini's marking D.C. senza Replica and repeats the last four measures of the caprice. Primrose's performance of this caprice highlights once again his virtuosity and extremely advanced left hand technique, especially with double stops in the middle section, which he plays in the tempo of between 120 and 124 equal dotted crotchets.

The last on the list of the four caprices chosen by Primrose is No.5. The mechanical motion of the middle section of this caprice challenges the performer with modulations of the arpeggios and scales-like runs. Perhaps the main difficulty for violists is clarity of the finger work in the required tempo. Primrose challenges the other viola performers by playing the middle section in the tempo of 184 equal crotchets. He ignores the introduction and begins directly from the middle section. In the final cadenza, Primrose includes some double stops into the last run of the caprice.

\footnotetext{
52 William primrose plays Paganini No.13, available from http://www.mp3chief.com/music/william-primrosepaganini-caprice-no-13 (accessed 18/10/2014)

${ }^{53}$ Franz Liszt, Etudes d'execution transcendante d'apres Paganini, S.140, (1838), available from hppts://www.hyperion-records.co.uk/tw.asp? w=W6438 (accessed 29/06/2016)
} 
There are different stages to the experiences one may have while learning the caprices, from fear of the posed technical difficulties and simple muscle pain from extending fingers, to disappointment in the quality of the first performance, to the joyous freeing of one's mind from techniques that opens the way to discovering the musical value of these caprices.

After two and a half years practicing caprices I have noticed enormous changes in my technical abilities: I need significantly less time to 'warm up' before a performance or practice, my left hand fingers are stronger, and I often utilise my newfound abilities to extend my left hand fingers in a variety of different compositions. I have also found it beneficial for my psychological disposition towards learning new pieces from the virtuoso repertoire and performing them. As a result of dedicating a significant part of my daily routine to the caprices, there are now no technical challenges that strike me as unplayable, since the majority of the advanced techniques of the post-Paganini musical styles replicate technical elements explored by Paganini in his Caprices. It fascinates me that one performer managed to assemble all these elements in one book of twenty-four pieces, which originally were not even designed as concert pieces but were intended to be technical exercises.

Paganini's 24 Capricci per violin solo are the quintessence of virtuoso violin technique, and many other instruments, including the viola, have successfully adopted them. This adaptation created a new concept of virtuosity for the viola: inspired by Primrose's performances of this caprices, Milhaud did not restrain himself from the usage of technical elements derived from Paganini's caprices in his viola concertos. It will be especially evident in chapter III C dedicated to the Milhaud's viola concerto no.2, when I consider the influence of Primrose's concept of viola virtuosity on Milhaud's writing for the viola. 


\section{Ic. Paul Hindemith Konzertmusik for viola and large chamber orchestra, Op. 48 (1930)}

Hindemith's viola compositions represent a turning point in the perception of this instrument by the public, performers and composers. As the a result of my own conclusions from playing his pieces, I can say that in contrast to his predecessors, Hindemith was exploring a more physical way of making sound on the viola which requires more pressure on the bow and heavier bow strokes at the hill of the bow.

Hindemith's innovations in writing for the viola and his experimental exploration of the qualities of this instrument inspired Darius Milhaud to compose the Concerto No. 1 for viola and orchestra especially for Hindemith. Hindemith not only premiered this concerto and made valuable suggestions regarding the orchestration, but he also returned the favour by writing the Konzertmusik for viola and large chamber orchestra Op. 48 and dedicated it to Darius and Madeleine Milhaud.

Konzertmusik, which was written by Paul Hindemith in 1930, one year after Milhaud's Viola Concerto No. 1, can be considered as a 'textbook' example of how to compose for viola. This work comprises a large variety of the progressive viola techniques of that era. The Konzertmusik consists of five movements:

1. Lebhaft. Bewegte Halbe (Lively. Moving half)

2. Ruhig gehend (Quietly going)

3. Lebhaft (Lively)

4. Leicht bewegt (Easily moved)

5. Sehr lebhaft (Very lively)

Even without playing or listening to the music - just by looking at the tempi indications - one can get an idea that most of this music will be very lively. Four out of the five movements are written to be performed at a fast, or very fast tempo. Assuming that Hindemith was writing this opus in terms of his own knowledge of viola, and using techniques he was comfortable performing, this work implies that he was the leading contemporary viola soloist. Every movement is technically very demanding and showcases 
the viola as a solo instrument. In each movement Hindemith extends the technical challenges.

Throughout the first movement, marked 'Lebhaft. Bewegte Halbe', Hindemith uses the viola's higher positions extensively. The enthusiastic character of this movement serves well as the opening of the concerto. The main theme of this movement is energetic with a staccato bow stroke to be played forte. (See Mus. ex. 26) Immediately, within three lines of this theme, Hindemith covers the entire range of the viola; from the fifth position of the starting note, the melody climbs up to the eighth position at the climax and slides back to the first position by a concealed descending chromatic scale. The progression of dynamic from forte at the beginning to fortissimo in the last three bars creates a powerful introduction of the theme.

Mus. ex. 26. Paul Hindemith, Konzertmusik, op. 48, Main theme $1^{\text {st }}$ movement bars $21-24 . .^{54}$

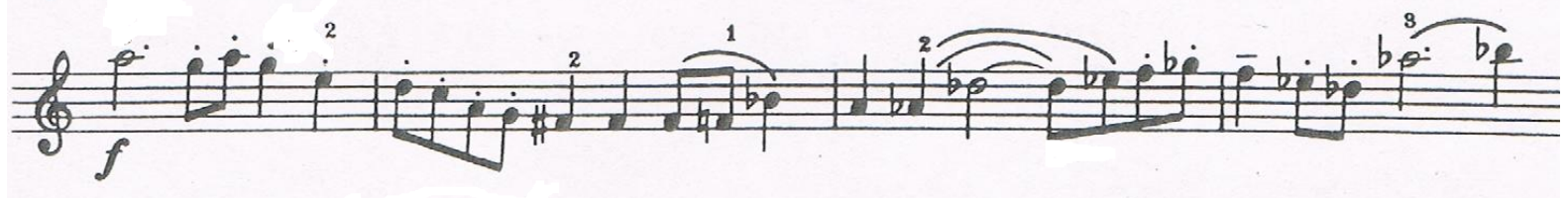

The second theme appears as an antithesis to the first theme. The melody crawls up to a higher register and louder dynamic and suddenly transforms into the first theme. (See Mus. ex. 27)

${ }^{54}$ All musical examples from this work are taken from E. Strahov's edition: Paul Hindemith, Концертная Музыка для альта и камерного оркестра Opus 48, (Moskow: Издательство, 1976). 
Mus. ex.27. Paul Hindemith, Konzertmusik, op. 48 Second theme $1^{\text {st }}$ movement bars41-46.
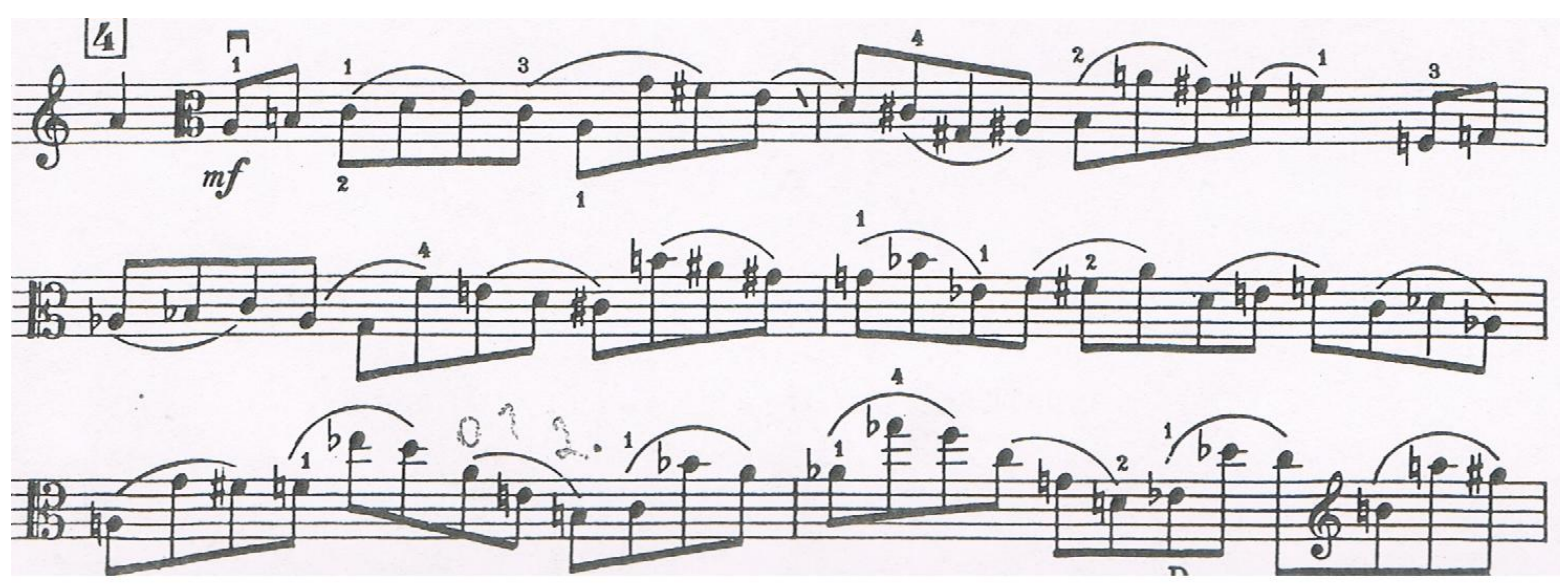

The high-pitched tune is interrupted by one of Hindemith's favourite techniques or elements - an ascending sequence of chords which progresses from the lower register, played piano, to the high positions and fortissimo. (See Mus. ex. 28) This element became one of the Hindemith' trademark techniques and later he would utilise it in the first movement of Der Schwanendreher.

Mus. ex. 28. Paul Hindemith, Konzertmusik, op. 48, $1^{\text {st }}$ movement, bars 62-70.
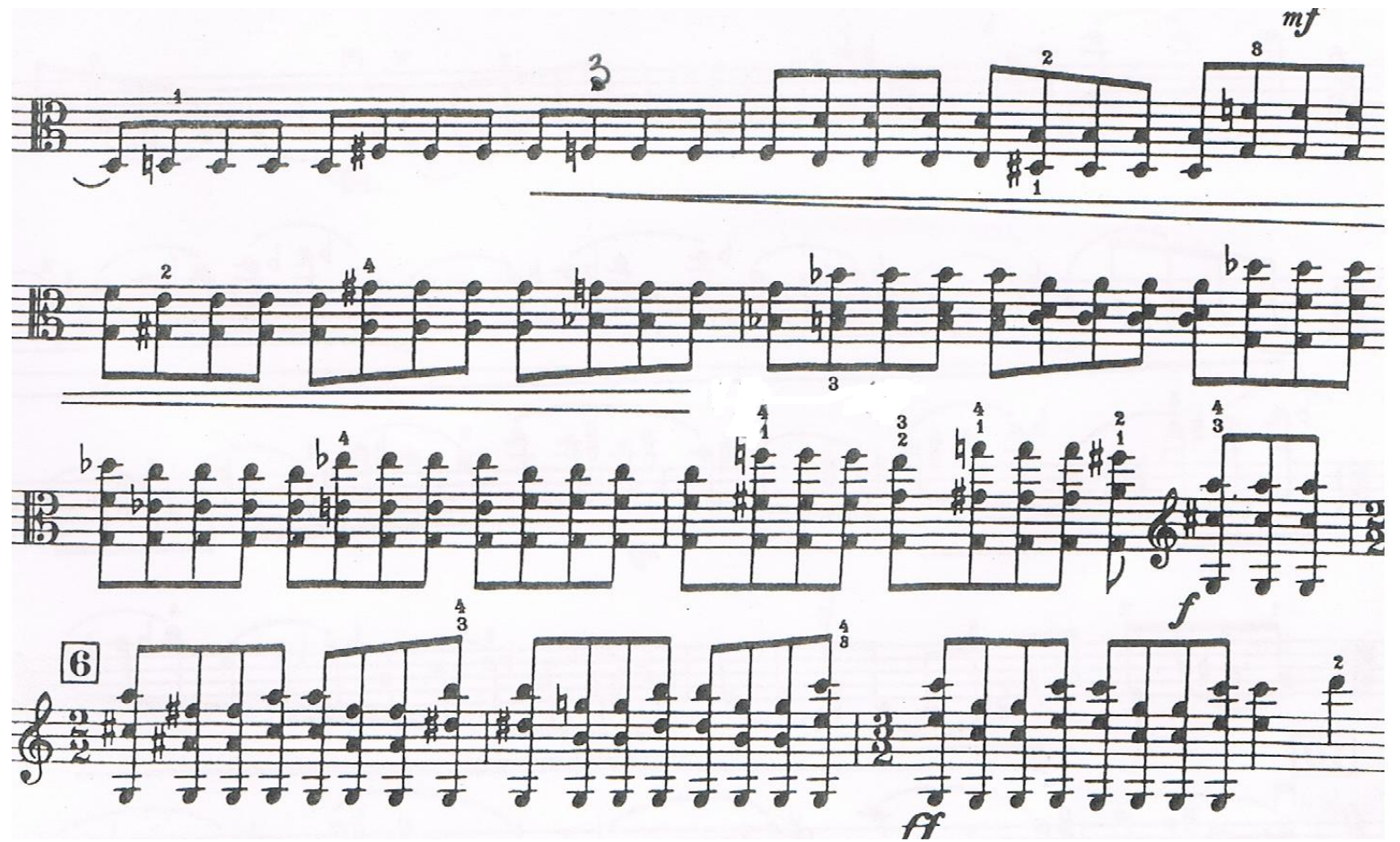
The recapitulation is a faint echo of the exposition. It begins piano, which does not progress beyond mezzo forte. At the conclusion, the first movement fades away with diminuendo from piano to pianissimo. An unexpectedly indecisive ending serves as an invitation to the second movement, and prepares the listener for its sombre harmonies.

The first movement is the least technically demanding, the tempo indicated by Hindemith (minim equals one hundred and twenty) is realistically playable, although a little too rushed. Perhaps this shows a hint of the influence of Milhaud, who was well known for his breakneck tempi indications.

Hindemith does not use unreasonably long shifts or extend beyond the ninth position in the first movement. The double stops and chords are well adjusted to the viola range and width of the fingerboard. This movement demands extensive knowledge of the fingerboard and experience in enharmonic exchange. The executions of the chord sequences can be challenging in terms of the intonation in the exposition, where the two top notes of each chord are positioned against an open string.

The second movement, which follows without a break from the first movement, 'Ruhig gehend' - is divided into two sections. The first section 'Ruhig gehend' is written in the reasonably slow tempo of dotted minim equals forty to fifty. The main theme of this section is introduced by the French horn and is passed to the viola after four bars (see Mus. exs. 29a and 29b)

Mus. ex. 29a. Paul Hindemith, Konzertmusik, op. $48,2^{\text {nd }}$ mvt, french chorn, bars1-4. ${ }^{55}$

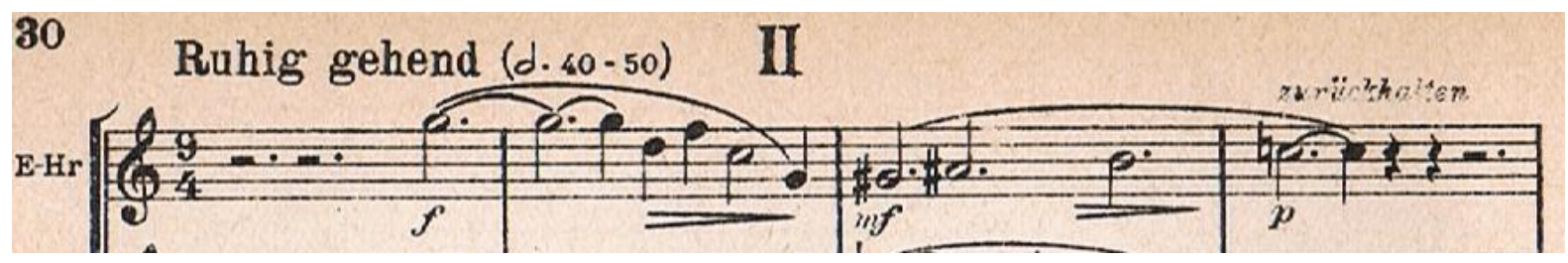

\footnotetext{
${ }^{55}$ All musical examples from this work are taken from Schott's edition: Paul Hindemith, Konzertmusik für Solobratsche und größeres Kammerorchester,(Leipzig: B.Schott's Söhne, 1930).
} 
Mus. ex. 29b. Paul Hindemith, Konzertmusik, op. 48, $2^{\text {nd }}$ mvt, viola, bars 5-8.

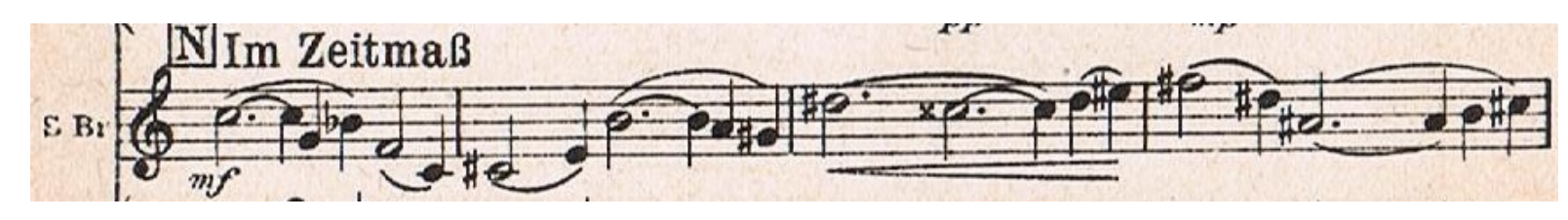

In contrast to the major tonality of the first movement, this theme is sombre and dark by nature. The beautiful melody is highly expressive. Hindemith uses predominantly the middle range of the viola and avoids the high register. Perhaps as if disguising the tragic character of this theme, Hindemith avoids loud dynamics - a forte appears very briefly in the middle of the section.

Long melodic lines, a 'liquid' rhythm that has notes tied over the bar line, and dynamic waves create a sense of perpetual motion in the music. Hindemith uses the ruhig fließend tempo indication that translates as 'quietly flowing'. The last four bars of the first section melt away in the pianissimo and zurükhalten- a 'held back' or 'restrained' tempo indication. This is like a calm sea before the storm: simmering water disrupted by the occasional wave that predicts the arrival of the demolishing power of nature.

The second section of this movement 'Bewegter' (moving) is fast and forceful. It begins forte in the sixth position. Each note is accentuated and very soon the dynamic progresses to fortissimo (see Mus. ex. 30). The fortissimo dynamic indication remains until the last four bars of the section where the tempo indication ruhiger werden appears. This can be translated as 'becoming quieter'.

Mus. ex.30. Paul Hindemith, Konzertmusik, op. 48, $2^{\text {nd }}$ movement, bars 65-72.

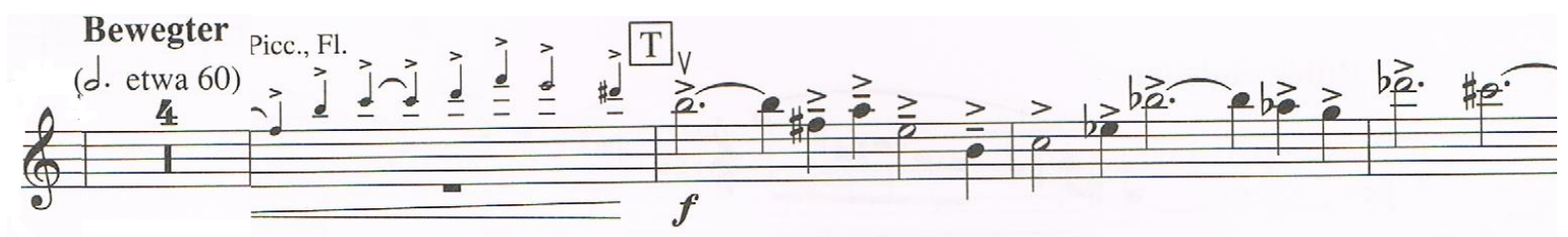

The coda of the second movement is a long chain of passages where accidentals appear on almost every note. Marked as Ruhig wie vorher - 'calm as before', the character 
of the coda is tranquil and soothing. The theme from the first section is played by the orchestra before returning to the solo viola in the last four bars of the coda, transposed an octave lower than in the exposition.

Each section of this movement poses a different technical challenge. The first section demands an accomplished bowing technique from the performer. I found it fascinating to work on discovering the most appropriate bowing, one that would not interrupt the flow of the melodic line and allow me to follow the busy dynamics of the melody. Even a slight change of the bow direction and/or the number of the notes in a slur can contribute to the altering of the original idea of Hindemith; this highlights the dilemma of the performer's role - should it to be a mere transmission of the composer's will by standing by the bowing marked by composer, or should the music be transformed through the prism of one's own personality and personal perception of the music by adjusting the bowing and potentially changing the phrasing?

The coordination of the accents (right hand) and vibrato (left hand), maintenance of the long lines of the fortissimo, high position playing and complex rhythms, these are the challenges of the second section of this movement.

In the coda, Hindemith uses a left hand technique known as 'crawling'. I found the best description of this in Ruggiero Ricci's method - 'Left-Hand Violin Technique':

"When employing the technique of crawling, it should be noted that the fingers precede the thumb. This is useful in avoiding a direct shift when the phrase demands a smooth continuity." 56

There is also another chance for a performer to execute the enharmonic exchange while playing the coda of this movement.

The third movement, 'Lebhaft', can be considered as the most challenging of the five. This movement is a relentless and endless bariolage in the solo viola part. Visually, this movement resembles the middle section of the Paganini caprice No.3. (See Mus. exs. 31a and 31b). Interestingly, Baillot's definition of bariolage as a technical element can be used as a precise description of the music of this movement:

${ }^{56}$ Ruggiero Ricci, Left-Hand Violin Technique, (New York: G.Schirmer, 1988) 
"The name bariolage is given to a type of passage which presents an appearance of disorder and bizarreness because the notes are not played one after the other on the same string." 57

Mus. ex. 31a. Paul Hindemith, Konzertmusik, op. 48 third movement bars 1-8.

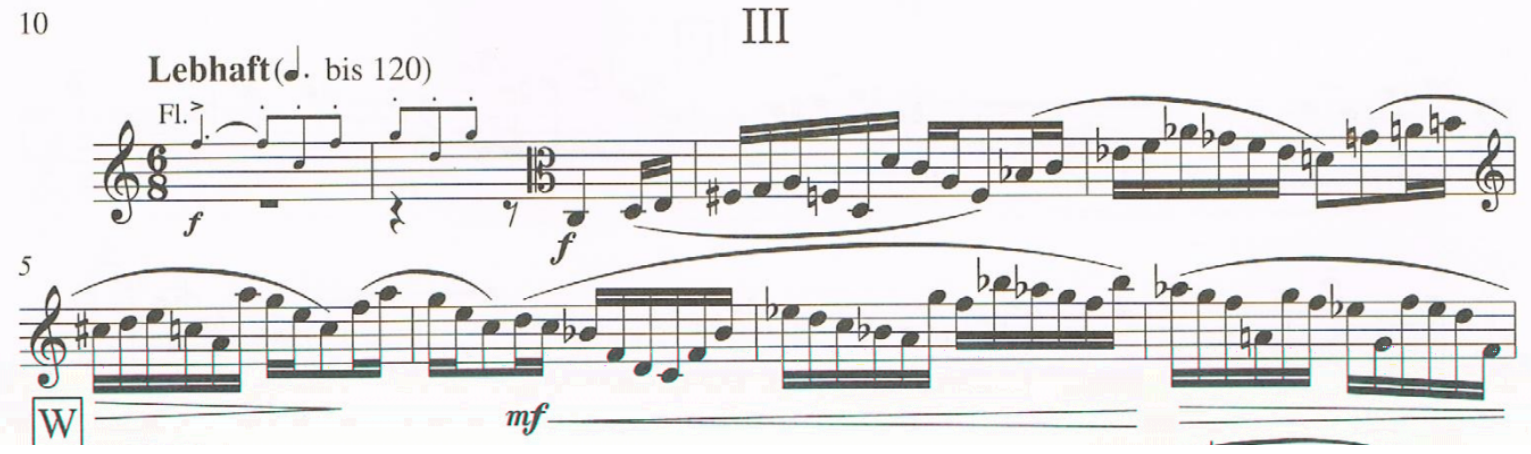

Mus. ex. 31b. Niccolo Paganini, transcribed for viola by Raby 24 Caprices, op. 1, Caprice No. 3 bars $25-37 .^{58}$

Presto

La liaison peut aussi se faire à piacere. | Die Bindung kann nach Belieben ausgeführt werden. | The slur can be executed at will.
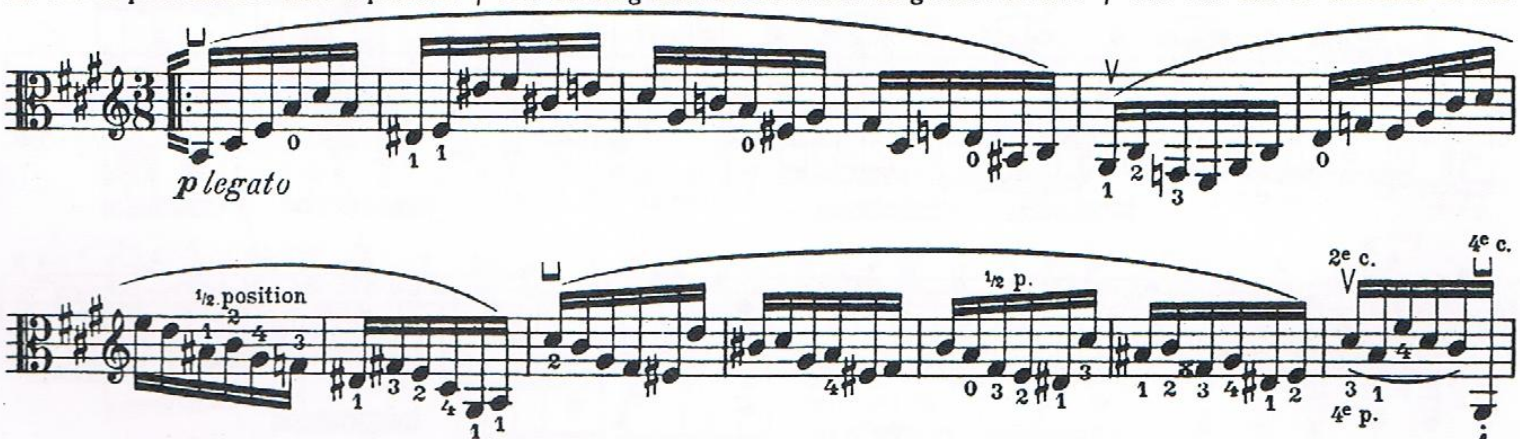

All the challenges of crawling technique, enharmonic exchange, high position playing and a fast tempo - dotted crotchet equals 120 -- fade away before the main problem, the collaboration of the soloist with the accompaniment. The semiquaver runs of the solo viola are contradicted by the rhythmical staccato of the scherzo-like theme, restricting the soloist rhythmically, and in some places the long chords of the orchestra do not provide any

57 Baillot, The Art of The Violin, p.219

58 Nicolò Paganini, 24 Caprices Opus 1, No.3, transcribed by L. Raby, (New York: Kalmus K 04293, 1985). 
rhythmical support. This situation requires absolute rhythmic stability from both the soloist and orchestra.

The fourth movement, marked 'Leicht bewegt', was written in the best traditions of the scherzo of the beginning of twentieth century, and it contains two contrasting elements. The first element is playful and light, with staccato, accents, and syncopated rhythms. (See Mus. ex. 32). The second element of this movement contains the inner conflict between the bow stroke, dynamic and the rhythm. Long slurs suggest continuous and smooth melodic lines. The piano dynamic is soothing and pacifying, but all this is contradicted by a very crisp rhythm of dotted semiquavers and demisemiquavers (see Mus. ex. 33).

Mus. ex. 32. Paul Hindemith, Konzertmusik op. $48,4^{\text {th }}$ movement, bars 1-8.

Leicht bewegt $d_{96}=104$

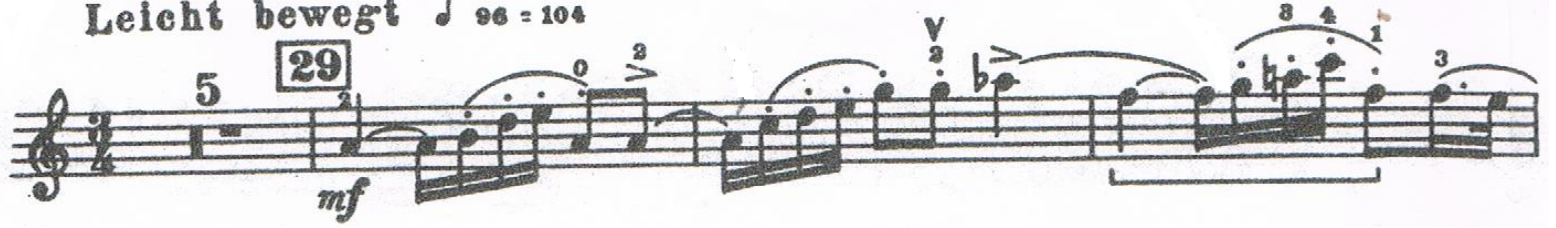

Mus. ex. 33. Paul Hindemith, Konzertmusik op. $48,4^{\text {th }}$ movement bars 50-55.

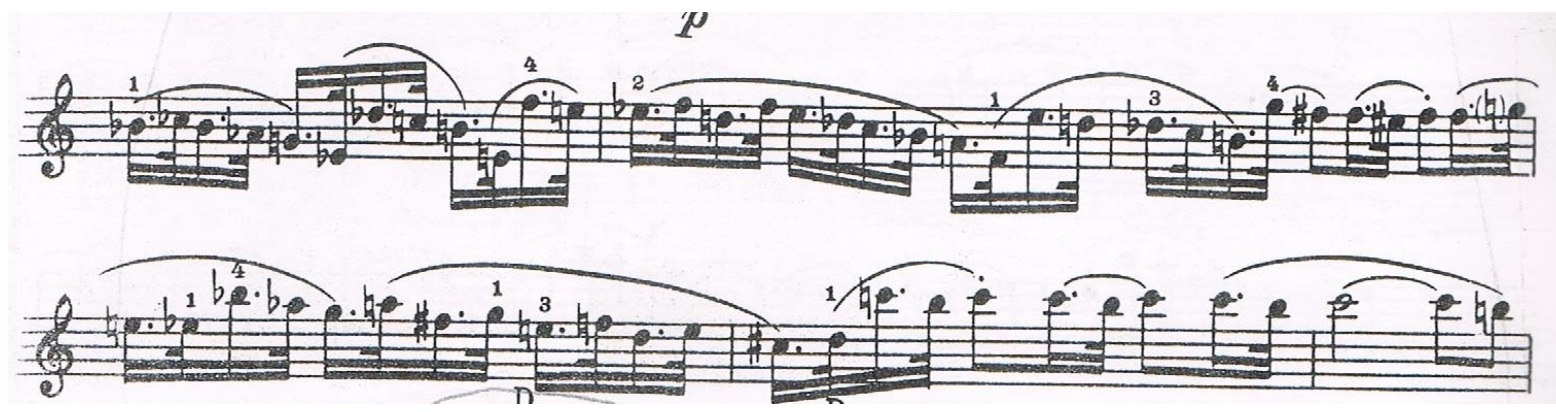

In the exposition, Hindemith explores the qualities of the viola that are similar to those of the violin - effortless virtuosity and lightness of touch. In the middle section, in an intentional contradiction, the first element reappears in the lower register. It starts on the $C$ string and is complicated by chords and double stops (see Mus. ex. 34). 
Mus. ex. 34. Paul Hindemith, Konzertmusik op. $48,4^{\text {th }}$ movement bars 65-73.

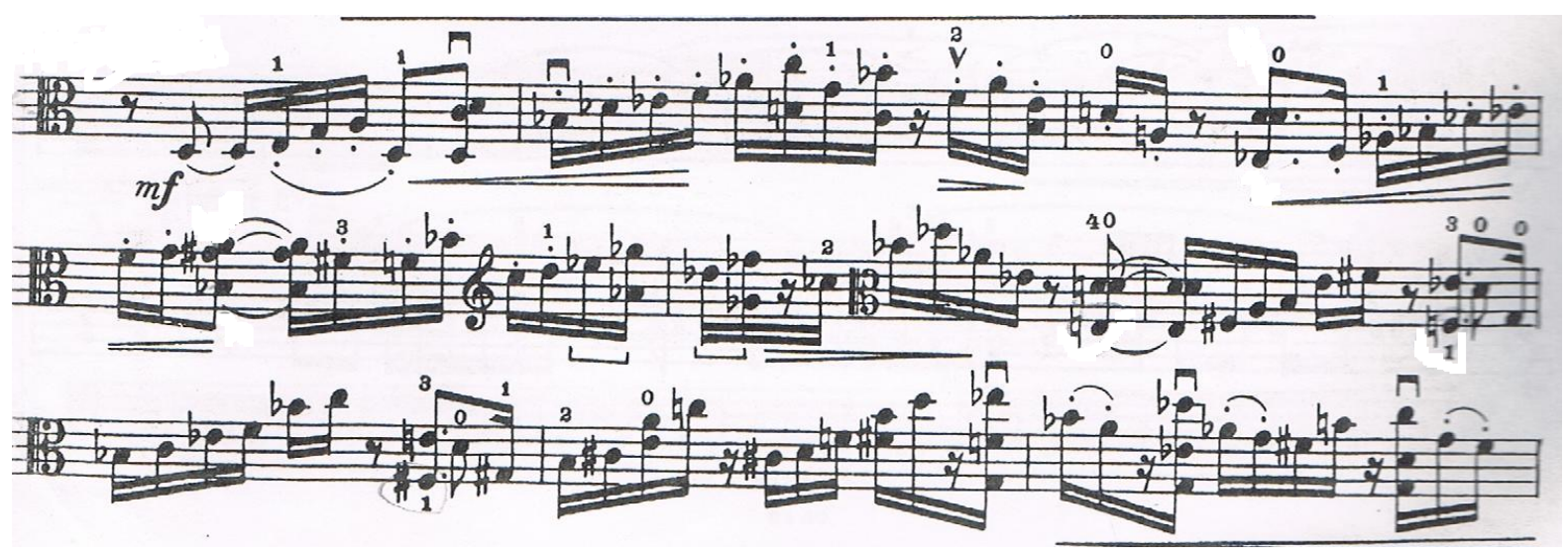

This cadenza poses the greatest difficulty in the fourth movement. The low register and the thicker strings of the viola ask for a more physical approach to the material. However, there is no time to relax and slow down, as the soloist is restricted and potentially compromised by the short, choppy, orchestral motifs. Certainly, it is difficult to execute the cadenza in the required tempo, but once again all these elements - double stops, chords, shifts - are well suited to the viola's inherent qualities.

The fifth movement, marked 'Sehr lebhaft', is a musical representation of public celebrations -- a popular theme for the finale of a concerto or symphony of the time. The breakneck tempo indicated by Hindemith - crotchet equals 152-160 - certainly, requires very fast fingers. Hindemith complicates it even further by adding embellishments to the melody (see Mus. ex. 35).

Mus. ex. 35. Paul Hindemith, Konzertmusik op. $48,5^{\text {th }}$ movement bars $1-15$.

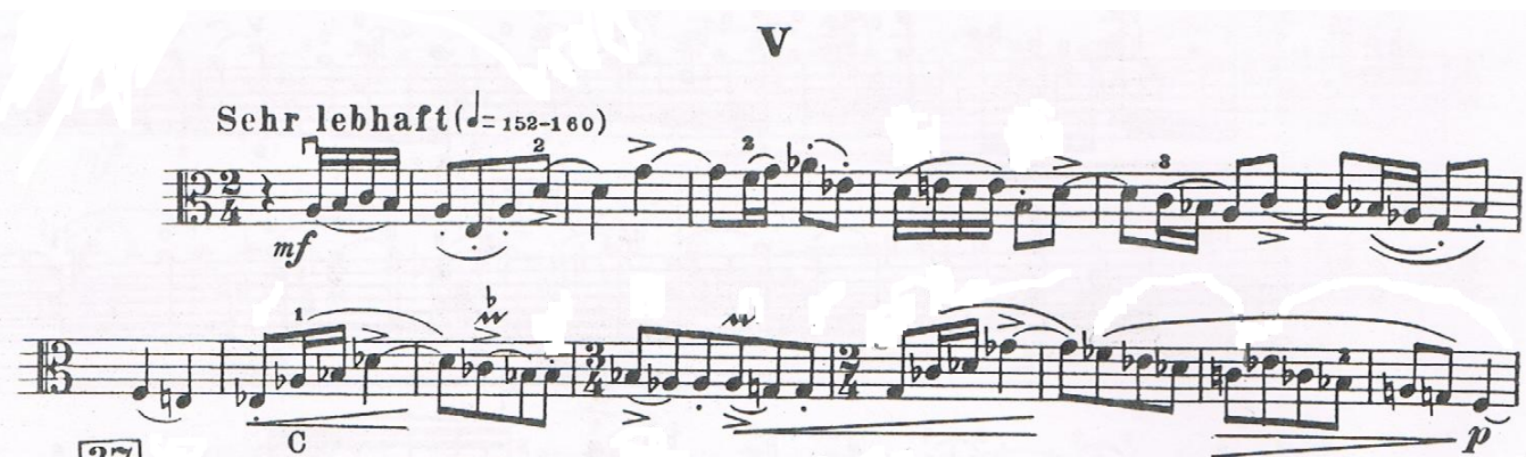


Hindemith's understanding of viola virtuoso techniques was based on his ongoing experience as an active, performing violist. He employs a wide range of virtuoso techniques: double stops, fast tempi, high positions and a variety of bow strokes, but does not use non-typical extensions and contractions, melodic lines or phrases built of entire harmonics and crossing over two strings. Hindemith is applying virtuoso techniques from the violin range to the specific qualities of the viola. His use of progressive, virtuoso techniques is very logical: it is all very much playable, and, as we say, 'under the fingers'; however, extremely fast tempi make his compositions more challenging for a performer. Hindemith's music can be very challenging without a good knowledge of the fingerboard, fluency in enharmonic exchange and position playing.

The discussions about all these various example of virtuoso writing for the viola in this chapter are leading towards and preparing the grounds for the next part of this thesis. Seemingly absent connections between Paganini's music and Primrose's transcriptions with Hindemith's and Milhaud's virtuoso writing for the viola will come to light, once the direct and indirect impact that was made by these composers / performers on Milhaud's virtuoso writing for the viola is revealed. There will be references to the pieces that have been discussed in this chapter, and stylistic elements and techniques from these pieces will be compared with Milhaud's viola concertos. 


\section{The influence of virtuoso performers on composers}

\section{Ila. Introduction}

Commonly, composers of the Romantic era were prolific performers as well, and of course they had to promote their own abilities and unique qualities. This encouraged them to create compositions filled with new virtuoso techniques in an attempt to entertain an audience through- and with their personality. At the top of the list of the performers/composers who initiated the movement of virtuoso writing was Nicolò Paganini. His mysterious and controversial figure, and his unexcelled virtuoso techniques not only enchanted the concertgoers but also inspired many of his contemporary composers to copy his style and to transfer his techniques into the repertoire of other instruments. Richard Leppert, in his article 'Cultural Contradiction, Idolatry, and the Piano Virtuoso: Franz Liszt' describing the attention of the public attracted by Paganini on violin and Liszt on piano as 'bordered on fetishism, a phenomenon in which an object or person becomes a locus of displaced desire'. ${ }^{59}$ However, Paganini's unexcelled virtuosity is only one of many ingredients of his successful career, according to Henry Roth, "Thus, in combining Paganini's instinctual expertise as a self-publicist with his amazing fingerboard feats, and adding to this the singular features of his appearance and dress, we have the supreme $19^{\text {th }}$-century massaudience virtuoso, the ultimate heroic 'Knight of the Violin'."

There are reasonable grounds for the assumption that Paganini was one of the most important virtuoso performers to have a great influence on other composers during his lifetime. Henry Roth saying, 'both Liszt and Schumann were tremendously impressed and influenced by Paganini. ${ }^{61}$ However, it was not a direct influence - he did not participate in the process of creating musical items. During my research I came across only one composition that was written for Paganini - 'Harold in Italy' by Hector Berlioz ${ }^{62}, 63$. Paganini

\footnotetext{
${ }^{59}$ Richard Leppert, 'Cultural Contradiction, Idolatry, and the Piano Virtuoso: Franz Liszt', in James Parakilas (ed.), Piano Roles: Three Hundred Years of Life with the Piano, (New Haven and London: Yale University Press, 1999), p.252.

${ }^{60}$ Henry Roth, Violin Virtuosos. From Paganini to the $21^{\text {st }}$ Century, (Los Angeles: California Classics Books, 1997), p.12.

${ }^{61}$ Roth, Violin Virtuosos. From Paganini to the $21^{\text {st }}$ Cantury, p.15.

${ }^{62}$ Berlioz, Hector. Harold in Italy, Symphony in Four Parts with Viola Obbligato, Op. 16, 1834.
} 
also made an indirect impact on the music of twentieth century composers such as Darius Milhaud, who utilised in his compositions many virtuoso techniques that can be attributed to Paganini's style. Milhaud was well known for being easily influenced by the performers of his time. In fact, every piece written by Milhaud for the viola is dedicated to a violist. In her interview with Kenneth Martinson ${ }^{64}$, the composer's widow Madeleine Milhaud recalled that "...in fact it's certain that for Darius, it had an influence if the person was a good player." 65

The roots of Milhaud's fascination with virtuosity lie in his early childhood experiences. Milhaud began to play violin when he was seven years old. In his autobiography 'My Happy Life'-- Milhaud describes his first violin teacher as a 'delightful musician' who 'wanted to make a musician of me, not a virtuoso'. Milhaud recalls that at the age of 10 he could already play virtuoso pieces and his parents thought that he might become a virtuoso. They supported Milhaud's interest in music and used to take him to Marseilles to concerts. Milhaud wrote in his autobiography:

My parents took me... (to concerts)... when a virtuoso was going to play one of the concertos I had been studying. I remember hearing in this way Pablo de Sarasate, that truly great violinist, give dazzling interpretations of the Saent-Saëns concerto and of a few of his own entertaining compositions; Eugéne Ysaye, the prince of violinists, whose playing held both depth and sobriety; Jacques Thibaud, sensitive and elegant; Jan Kubelik, a brilliantly dexterous virtuoso. ${ }^{66}$

It is evident, that his encounters with those great violinists of that time made a very strong impression on the young Milhaud and encouraged him to set very high standards in his perception of virtuoso music and virtuoso performance. Not only was he very demanding towards other musicians, but also he was very critical of his own abilities as a

\footnotetext{
63 J.R. Girard, 'Hector Berlioz's “Harold en Italie”' A Performance Guide available from https://urresearch.rochester.edu/fileDownloadForInstitutionalltem.action. by JR Girard - 2012 (accessed 26 April 2016).

${ }^{64}$ Martinson, Kenneth http://www.kennethmartinson.com (accessed 01 March 2013).

${ }^{65}$ Martinson, Kenneth. Interview with Madeleine Milhaud, available from http://www.nigun.info/fmilhaud.html. (accessed 10 March 2013).

${ }^{66}$ Darius Milhaud, My Happy Life, An Autobiography (London, New York: Marion Boyars 1995), p.32.
} 
performer. Milhaud decided to discontinue his course of violin studies at the Paris Conservatorium after receiving the second, but not the first prize.

Being one of the most prolific composers of the $20^{\text {th }}$ century, Milhaud was surrounded by many virtuoso musicians. Close friendships and working relationships with such musicians as Paul Hindemith, William Primrose and members of the Pro Arte string quartet, combined with his own experiences as a performer, encouraged Milhaud to write virtuoso pieces for various instruments. Those relationships are evident in all of his pieces for the viola; in the dedications to one or another performer, and in Milhaud's incredible ability to infuse a musical item with the characteristic qualities of the performer to whom it was dedicated.

The importance of Milhaud's associations with virtuoso performers is especially evident in the Second Concerto, which can be considered the Pinnacle of virtuosity. In this Concerto Milhaud amalgamated the demanding techniques that he had acquired during his violin studies, in particular, elements that could be easily attributed to Niccolo Paganini's style of composition. His associations with the two most prolific violists of the $20^{\text {th }}$ century Paul Hindemith and William Primrose -- had an enormous impact on this concerto, not only in terms of how Milhaud used virtuoso techniques, but also how he infused his own highly recognisable style with those of Hindemith and Primrose.

Both concertos were written for two luminaries of viola music during the twentieth century. Concerto No. 1 was written for and dedicated to Paul Hindemith. Concerto No. 2 was commissioned by and dedicated to William Primrose. These outstanding virtuoso violists premiered both concertos. However, Concerto No. 1 has been successfully 'installed' into the viola concert repertoire. Was Hindemith's enthusiastic feedback a part of this success? In sharp contrast, the Concerto No. 2 has been forgotten for more than 50 years. I cannot say with complete assurance that this concerto was never performed after the première. However, I was unable to find any information to prove either way - to confirm or deny further performances. Could it be that the description of this concerto by Primrose as the 'most outrageously difficult work; and that it would never appeal to the public', be to blame?

The goal of my investigations was to prove or eliminate the three main factors that could have potentially contributed towards the fate of the concerto: the musical 
unattractiveness for the listener, the unreasonable technical expectations posed for the performer, and the misfortune of the cold relationships between Milhaud and Primrose.

The way to find an objective answer to the question about the musical attractiveness of this opus is to learn this concerto, to perform it more than once, and to collect feedback from listeners, fellow musicians and supervisors. The answer to the question about appropriateness of the techniques used by Milhaud lies in comparing this concerto with the other pieces from the virtuoso viola repertoire, including his own Concerto No. 1 and compositions by Hindemith and Paganini. Also, an investigation into the history of the creation of these two concertos and the relationship between Milhaud and Hindemith, and Milhaud and Primrose, has helped to establish the degree of influence of those performers on the composer.

\section{IIb. Darius Milhaud and Paul Hindemith: relationship. Darius Milhaud Viola Concerto No.1, Op.108 (1929) dedicated to Paul Hindemith}

Arguably, the story of the working relationship and friendship between Darius Milhaud and Paul Hindemith can be considered one of the finest examples of crossinfluence between a composer (Milhaud) and a virtuoso performer (Hindemith), who was also a renowned composer. A brief outline of the similarities and differences in their respective backgrounds has helped me to find evidence of the cross-influence between these two composers.

Milhaud and Hindemith both studied violin and became advanced violin students, Milhaud at the Paris Conservatory, and Hindemith at the Hoch'sche Konservatorium in Frankfurt. However, their performing careers were very different. Milhaud abandoned his violin studies at the Paris Conservatory after the second year. He wrote about his decision in his autobiography 'Notes without Music':

As my musicianly talent developed, I found the study of the violin increasingly tedious; it was as if I was being robbed of time which otherwise I could have devoted to composition. I was awarded no prize at the Concours of 1912, and the idea of spending a third year on the study of the 
violin now seemed unbearable. I...announced my intention of abandoning my career as a violinist in order to be a composer. ${ }^{67}$

In contrast, Hindemith's performing career was very successful. In 1914, he was appointed as concertmaster of the Frankfurt Opera Orchestra and in the same year, he became second violinist in the Rebner Quartet. In 1921, Hindemith founded the Amar String Quartet and was compelled to pick up the viola as he was unable to find a suitable violist. Perhaps comparing the violin and viola in a practical, performing career helped Hindemith to understand differences between these two instruments.

Neither Hindemith nor Milhaud mentioned Paganini and his music in their autobiographies, or any other written materials. I can only assume that as advanced violin students, they studied Paganini. There is some evidence of Milhaud's interest in Paganini's music, however. He arranged three caprices for violin and piano in 1927. Both Hindemith and Milhaud respected J. S. Bach. Hindemith referred to Bach as 'my only predecessor in composition in Germany'. Milhaud followed the official manifesto of Le Six, enunciated by Jean Cocteau; they did not have time for German music, with the exception of J. S. Bach.

They met for the first time in 1927, when Paul Hindemith asked Darius Milhaud to compose a short opera for his summer festival in Baden-Baden. Darius Milhaud agreed, and wrote L'Enlevement d'Europe based on the libretto of Henri Hoppenot ${ }^{68}$. During the following year, Hindemith once again reached out to Milhaud when he was seeking support for his new idea for the second summer festival in Baden-Baden. In his letter to Darius Milhaud from Berlin, dated January-April 1928, Hindemith wrote:

Dear Milhaud, do you remember this little collection of compositions 'Das neue Werk' you saw last summer in Baden-Baden, containing little pieces for ...the 'musicalische Jugendbewegung'(Youth-motion(!!!)) for schools, dilettantes etc. etc.? Please have the kindness and send me anything to complete this collection... I would prefer Instrumental pieces for two violins, alto \& cello, singular or orchestral... The execution of these pieces... must

\footnotetext{
67 Milhaud, My Happy Life, p.43

${ }^{68}$ Henry Hoppenot available from http://daniellathompson.com/Texts/Le_Boeuf/boeuf.pt.30.htm (accessed 20/03/2014)
} 
be very easy!!...Short pieces, I think six or seven. Will you do it? Ich would be very glad... Please write me some words about it...

With the kindest regards for you and Mrs Madeleine,

Yours, Paul Hindemith

(Excuse my very bad English!!) ${ }^{69}$

Milhaud responded enthusiastically, and came up with Cantate de l'Enfant Prodigue a cantata in the chamber style. Many years later, in his autobiography 'Notes without Music' recollecting events, Milhaud wrote:

Hindemith was absolutely his own master, and tried out all kinds of musical experiments. In1927 he asked me to compose the opera, which had to be as short as possible....

In the following year, various cantatas and works written for the radio were produced at Baden-Baden....

Another year, they put on music specially written for the cinema... ${ }^{70}$

That was the beginning of a lifelong friendship between Paul Hindemith and Darius Milhaud. Both composers shared a desire to try new styles, instruments and musical elements. Both were attracted to the idea of the involvement of 'dilettantes' in the process of music making. These events led to the famous exchange of the viola concertos.

In 1929, Milhaud wrote his Viola Concerto No.1 and dedicated it to Paul Hindemith. Paul Hindemith in Amsterdam premiered this concerto on $15^{\text {th }}$ December 1929, with the Concertgebouw orchestra under the baton of Pierre Monteux ${ }^{71}$.

In one of her numerous interviews, Madeleine Milhaud refers to Hindemith as ...a very strange character. You know, Hindemith didn't work so well [as a violist]; he played as a composer. In fact, after the rehearsal in Amsterdam,

\footnotetext{
69 Paul Hindemith, Selected Letters of Paul Hindemith, Geoffrey Skelton, editor, translator (New Haven and London: Yale University Press, 1995) p.51.

${ }^{70}$ Milhaud, My Happy Life, pp.153154

${ }^{71}$ Pierre Monteux available from http://www.britannice.com/EBchecked/topic/390817/Pierre-Monteux (accessed 26/04/2016).
} 
Monteux said to Hindemith, "Now go in your room and study". He did, really $!^{72}$

The whole concerto is short - only 15 minutes - and as very often happens with Milhaud's works, the solo part on its own is delightfully tuneful even in the brisk movements, but an application of the orchestral/piano accompaniment immediately showers listeners with quite refreshing and unexpected harmonies. After the premiere, Hindemith asked Milhaud to revise the concerto so that he could have a smaller orchestra. The new version of the concerto was dated 1929, and was called a Viola Concerto with an orchestra of soloists. Following the advice of Hindemith, Milhaud reduced the orchestra to an ensemble of 15 soloists. (Table 1 ).

Table 1

\begin{tabular}{|l|l|l|}
\hline \multicolumn{3}{|c|}{ Orchestration } \\
\hline 1st edition (1929) & \multicolumn{2}{|c|}{ 2nd edition (1929) } \\
\hline 2 Flutes & 1 Flute & \\
\hline 2 Oboes & 1 Oboe & Bass Clarinet \\
\hline 3 Clarinets & 1 Clarinet & \\
\hline 2 Bassoons & 1 Bassoon & \\
\hline 2 Horns & 1 Horn & \\
\hline 2 Trumpets & 1 Trumpet & \\
\hline 1 Trombone & 1 Trombone & \\
\hline 1 Tuba & ------------- & \\
\hline Battery & Battery & \\
\hline Harp & ------------ & \\
\hline String Quintet & String Quintet & \\
\hline
\end{tabular}

${ }^{72}$ Kenneth Martinson, 'The viola music of Darius Milhaud', available from http://www.wiu.edu/music/articles/Milhaud.htm (accessed 26/04/2016) 
It was a significant reduction, from twenty-two musicians down to fifteen. This adjustment was certainly made by Milhaud out of respect for Hindemith. However, Milhaud did not discard the first orchestration and he reserved the right to offer both versions to performers. The comment on the piano reduction of this concerto leaves it to the performer to select the first or the second edition (See Mus. ex. 36).

Mus. ex. 36. Darius Milhaud, Concerto pour Alto et Orchestra, edition pour Alto et Piano ${ }^{73}$.

$N B$ Il existe en dehors de la version avec orchestre une version pour Alto et quinze instruments solistes (petite flute, flute, hautbois, clarinette, clarinette basse, basson, cor, trompette, trombone, batterie,deux violons, alto, violoncelle et contrebisse) Es gibt auch eine Fassung für Viola und fünfzehn Soloinstrumente (Piccolo, Flöte, Oboe, Klurinette, Baßklarinette, Fagott, Horn, Trompete, Posaune, Schlagwerk, zwei Violinen, Viola, Violoncell und Kontrabaß)

Copyright 1931 by Unioersal Edition Copyright renewed 1958

Universal Edition N1: 3718

Concerto No.1 for viola and orchestra consists of four movements:

I. Animé

II. Lent

III. Souple et Animé

IV. Vif

The first movement, 'Animé', opens with the repetition of a short motif of choppy chords that contrasts with the smooth legato triplet runs (see Mus. ex. 37).

Mus. ex. 37. Darius Milhaud, Concerto pour alto et orchestra, $1^{\text {st }}$ movement, Animé, bars 1-

9.
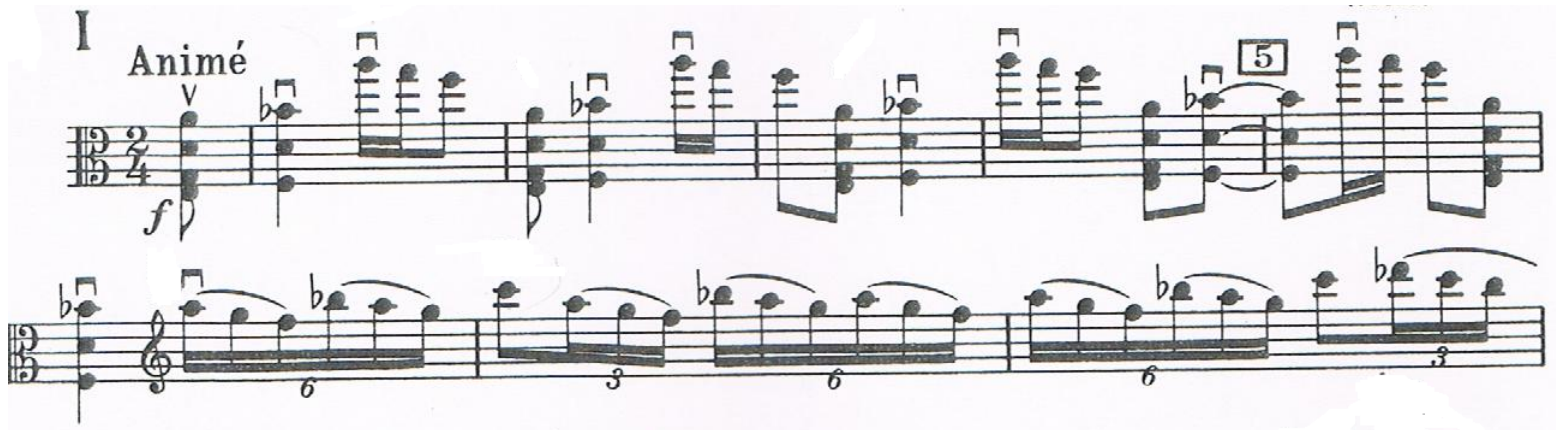

${ }^{73}$ All musical examples from this work are taken from Universal's edition: Darius Milhaud Concerto pour Alto et Orchestra, edition pour Alto et Piano, (Paris: Universal Edition Nr 3718a, 1958). 
This opening is strenuous for both the left and right hands. Rapid shifts between the first two chords and the next note require a good knowledge of the positions. "Strong" left hand fingers will help to execute good intonation. Co-ordination of the right and left hands is another important aspect - all the shifts and preparatory work of the left hand fingers must occur 'between the bows'. This is a physical challenge more than an example of virtuoso technique.

The whole movement is highly demanding technically. Milhaud seems to have deliberately 'packed' every single virtuoso technique he was familiar with into two pages.

One of the favourite elements is a sequence of broken intervals descending by semitones (see Mus. ex. 38). Milhaud used the same element in almost every piece for viola - Concertino d'Été, Sonata No. 2, 'The Wisconsonian', and his Concerto No. 2 for viola and orchestra.

Mus. ex. 38. Darius Milhaud, Concerto pour alto et orchestra, $1^{\text {st }}$ movement, Animé, bars $12-$ 15.

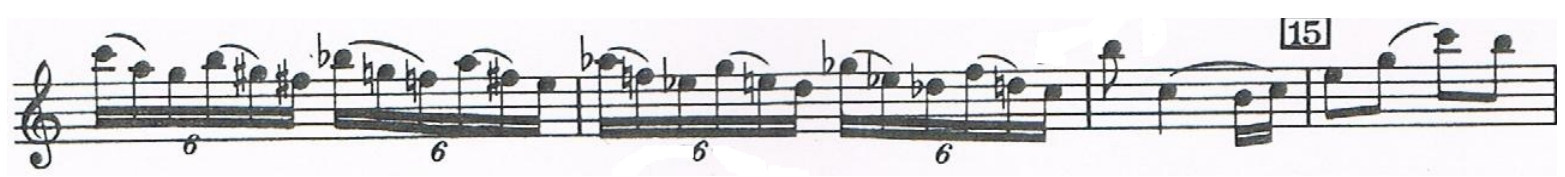

Milhaud uses double stops extensively in this movement. The passages of thirds are reminiscent of those from Paganini's Sonata per la Grand' Viola e orchestra and 24 Caprices Op. 1 (see Mus. exs. 39a, 39b and 39c).

Mus. ex. 39a. Darius Milhaud, Concerto pour alto et orchestra, $1^{\text {st }}$ movement, Animé, bars 53-55.

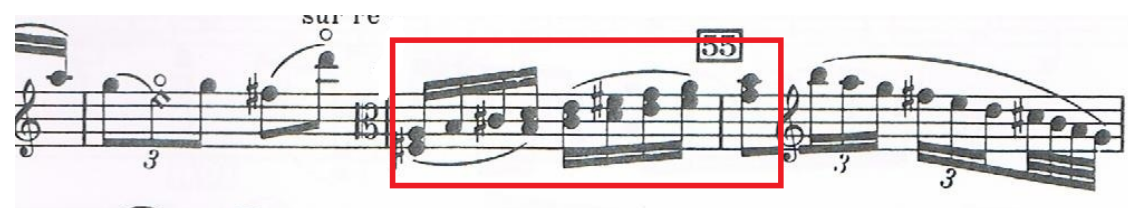


Mus. ex. 39b. Nicolò Paganini, Sonata per la Grand' Viola , Cantabile Andante sostenuto, bar 60.

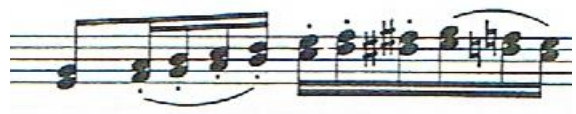

Mus. ex. 39c. Nicolò Paganini, 24 Caprices op. 1, No. 4, bar 59.

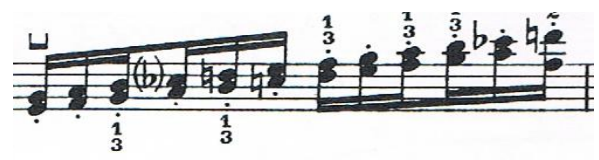

Another variety of double stops, which Milhaud used in many of his viola compositions, is ascending scales of thirds with the quavers in the lower line and the semiquavers in the top line (see Mus. ex. 40). At first, this element does not seem overly complicated as every second semiquaver of the top line could be played as an open string. However, to be able to sustain double sound, the fourth or third fingers must play the second semiquaver of the top line. This makes the element difficult in terms of intonation and sound production; therefore, it is advisable to use the open string which will not affect the quality of the sound or undermine the musical value; in contrast, it makes it easier for the soloist to cut through the busy texture of the accompaniment, because the sound of open string is brighter.

Mus. ex. 40. Darius Milhaud, Concerto pour alto et orchestra, $1^{\text {st }}$ movement, Animé, bars $42-$ 45.

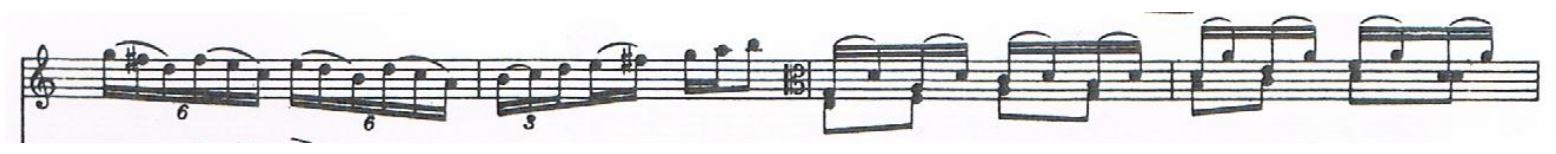

Rapid changing of positions occurs in almost every bar. Milhaud saved a particularly challenging example of this technical element for the ending of this movement. (See Mus. ex. 41). These three shifts occur within a very short period of time. An extra complication is that every time, the right hand travels to a different position: the first time to the eighth, second time to seventh, and the third time to the sixth position. 
Mus. ex. 41. Darius Milhaud, Concerto pour alto et orchestra, $1^{\text {st }}$ movement, Animé, bars $84-$ 88.

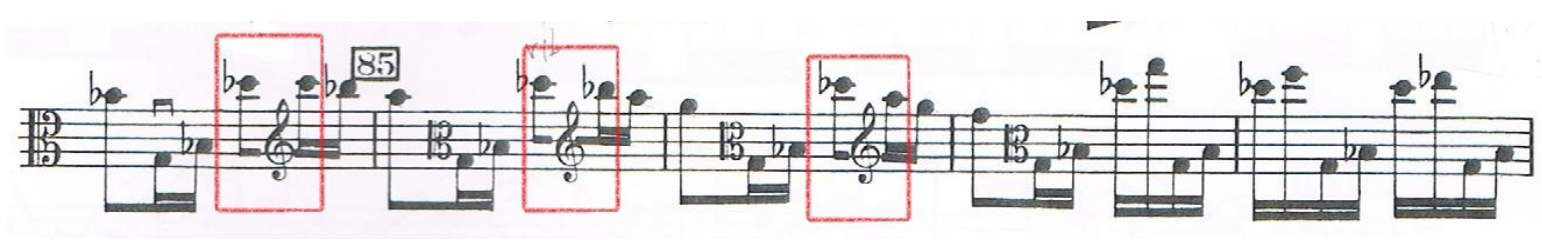

Dynamic markings are scarce: forte in the opening to mezzo forte in the middle of the first page, back to forte in the coda, and finishing with fortissimo. Overall, this movement is 'industrial' in its character with a choppy main theme and a contrasting second element, which is prevented from being too lyrical by the fast tempo and short slurs.

The second movement is the first of two slow movements, intentionally divergent from the intensity of the first movement. There is only one dynamic marking in the solo viola part throughout the whole movement - piano at the entrance. Milhaud gives artistic licence to the performer. An uncomplicated melody is reminiscent of medieval tunes. The accompaniment is polyphonic in structure and accentuates the choral-like qualities of the melody. The orchestra introduces the main theme of this movement. The simple texture and the presence of fourth and fifth intervals create a cross between a modernised Gregorian chant and a canon. The viola is left unaccompanied in its first entrance (see Mus. ex. 42). Avoiding shifts and using the crawling technique is helping to preserve the sense of clarity and simplicity set by the orchestra.

Mus. ex. 42. Darius Milhaud, Concerto pour alto et orchestra, $2^{\text {nd }}$ movement, Lent, bars 102106.

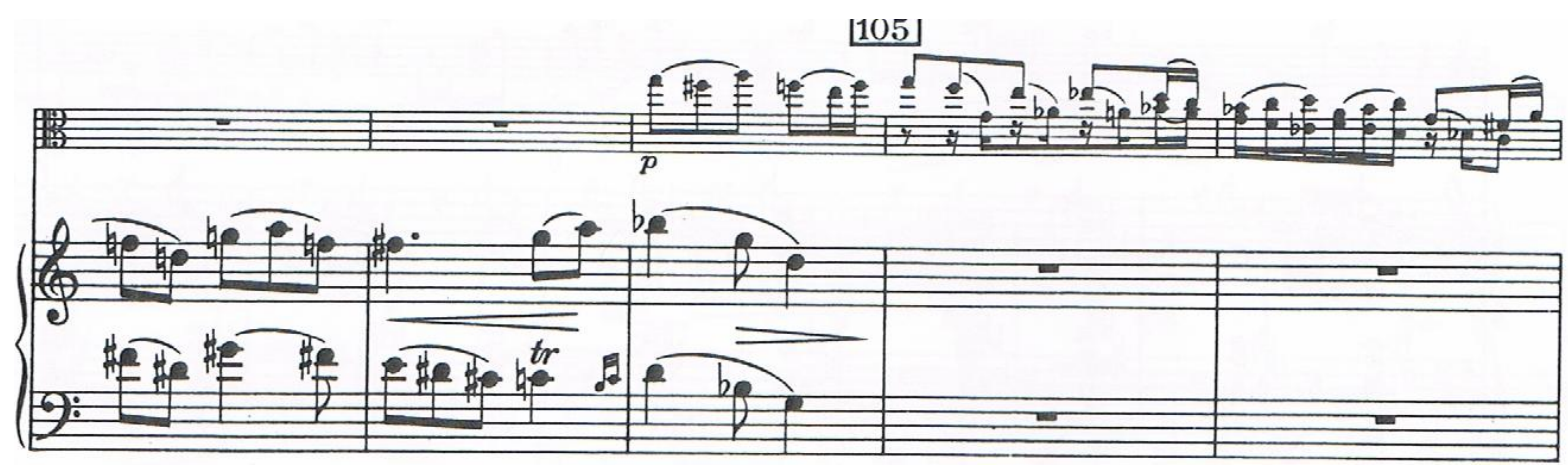


Throughout, the second movement posed an issue of creating smooth melodic lines. The left hand fingers techniques required in this movement include crawling and pivoting. For the right hand, string crossing is an important aspect.

Visually, one particular technical element stands out in this movement - the ascending by semitone arpeggiato chord sequences. This element looks very similar to the technique used by Paganini in his Sonata per la Grand' Viola e orchestra (see Mus. exs. 43a and 43b).

Mus. ex. 43a. Darius Milhaud, Concerto pour alto et orchestra, Lent, bars 140-141.

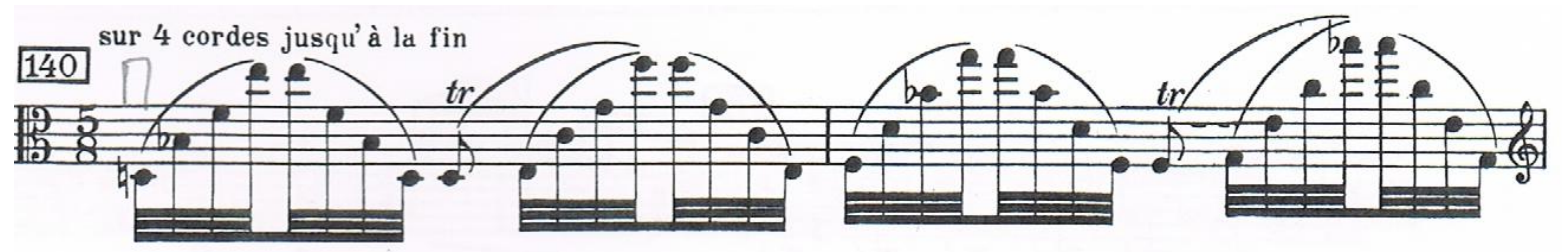

Mus. ex. 43b. Nicolò Paganini, Sonata per la Grand' viola e orchestra, variation 3, bars 165167.

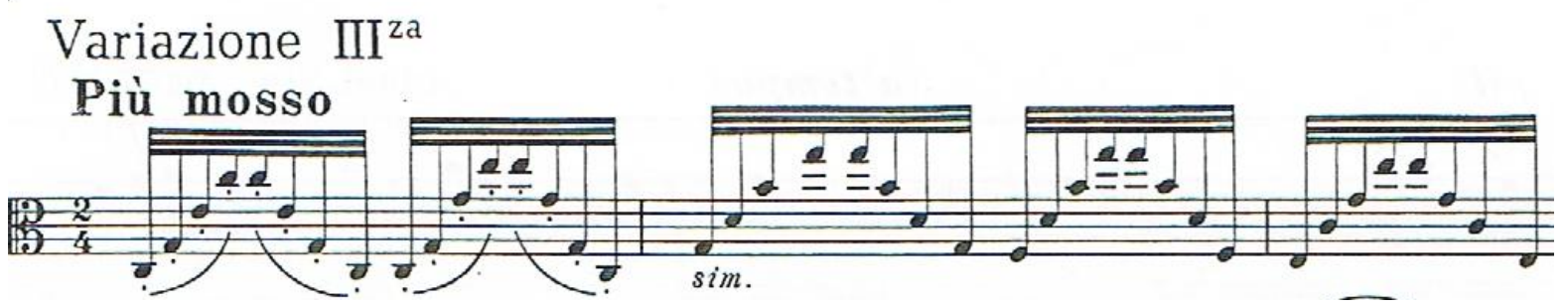

However, there is one very important difference in the way Paganini used this element in his sonata. In Paganini's viola version, left hand expansion is not required as all the arpeggios are arranged within the framework of an interval of a fourth between the first and fourth fingers - within the range of one position. Paganini acknowledged the larger size of the viola. By contrast, Milhaud uses an advanced variety of this technique, where the fourth finger must be extended to cover an interval larger than a fourth - a fifth and even a sixth (see Mus. exs. 44a and 44b). This difference confirms that Milhaud, who was very familiar with Paganini's music, applied technical elements from caprices to his viola concerto without adjusting them to the larger fingerboard of the instrument, perhaps 'copying' it from Paganini's Caprice No. 1 - another well-known example of this technique 
(see Mus. ex. 44c). The arpeggios where left hand fingers expansion is required are highlighted in red. It is evident.

Mus. ex. 44a. Darius Milhaud, Concerto pour alto et orchestra, Lent, bars 122-123.

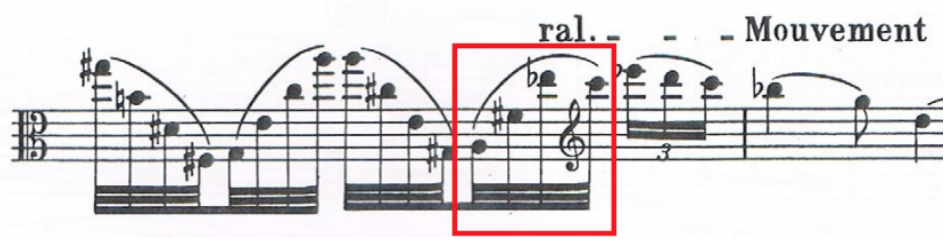

Mus. ex. 44b. Darius Milhaud, Concerto pour alto et orchestra, Lent, bars 140-141.

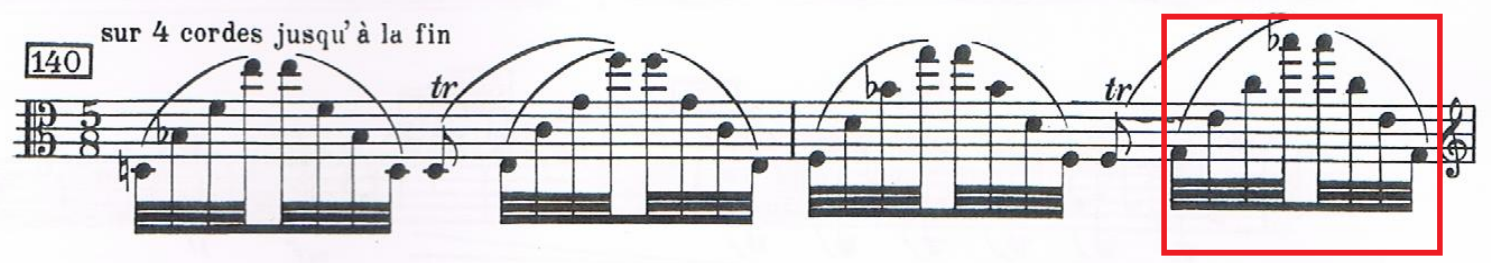

Mus. ex. 44c. Nicolò Paganini transcribed for the viola by L. Raby. 24 Caprices op. 1, No. 1, bars 9-12.

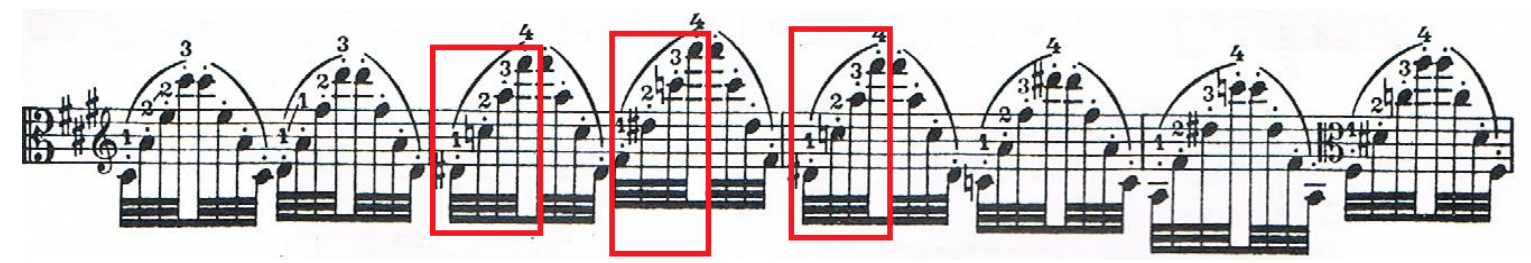

The third movement is marked 'Souple et Animé'. Its simple tune intensifies and becomes more complicated towards the middle of the movement, where the viola is left unaccompanied in a short virtuosic cadenza. The main theme from the opening appears unchanged in the coda (see Mus. ex. 45). 
Mus. ex. 45. Darius Milhaud, Concerto pour alto et orchestra, Souple et Anime, bars 148151.

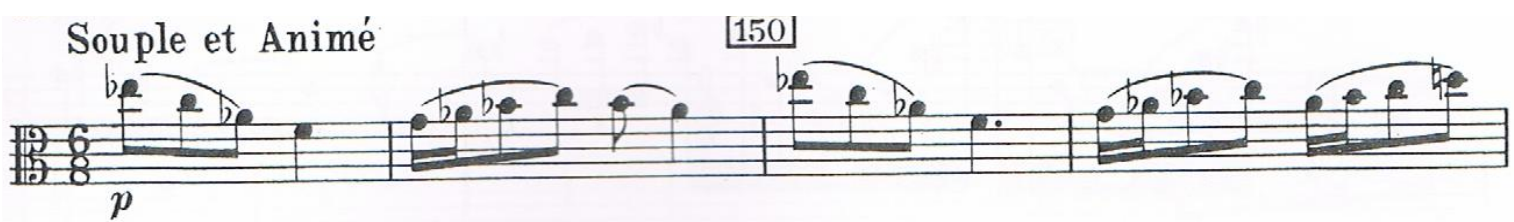

Amongst other virtuoso elements, Milhaud uses one of Paganini's favourite techniques - Devil's trill, a tune in the top voice accompanied by rhythmically organised trills in the lower voice, which is a more complex version of the double stops (see Mus. exs. $46 a$ and $46 b)$.

Mus. ex. 46a. Darius Milhaud, Concerto pour alto et orchestra, Souple et Anime, bars 167168.

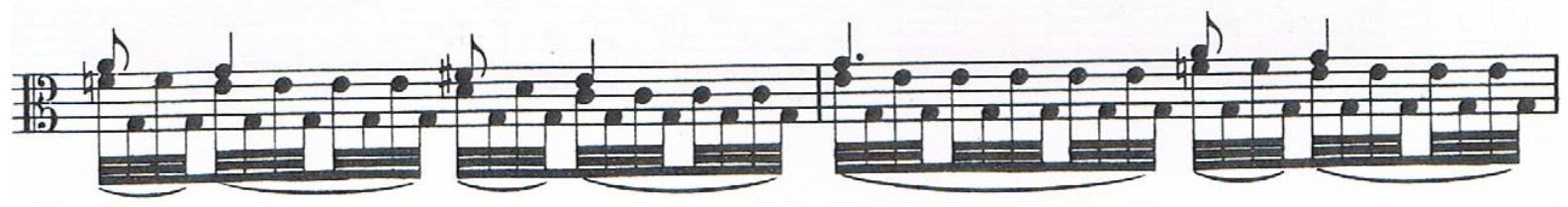

Mus. ex. 46b. Nicolò Paganini, Sonata per la Grand' Viola, Cantabile Andante sostenuto, bars 6-7.

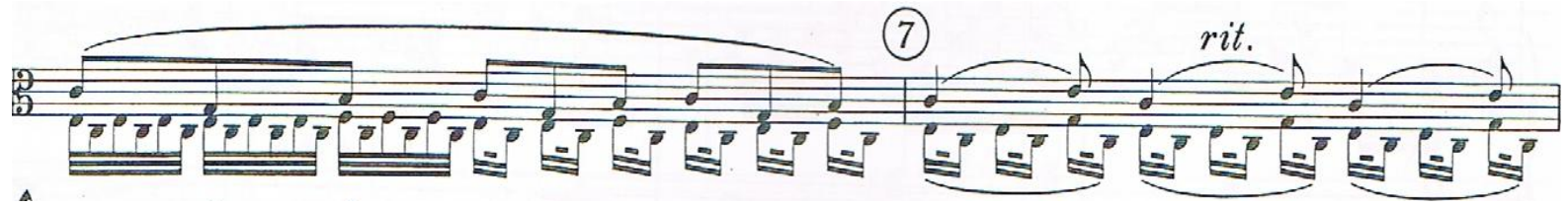

Virtuoso cadenza in the middle of this movement is developed from the moderate tempo and pianissimo dynamic into a ferocious sequence of fast passages. The scales of the broken fifth descending by semitones take a large part of the cadenza (see Mus. ex. 47). This element is not very demanding technically; however, it is a very effective tool, which creates an impression of top-end virtuosity. 
Mus. ex. 47. Darius Milhaud, Concerto pour alto et orchestra, Souple et Anime, bars 184187.
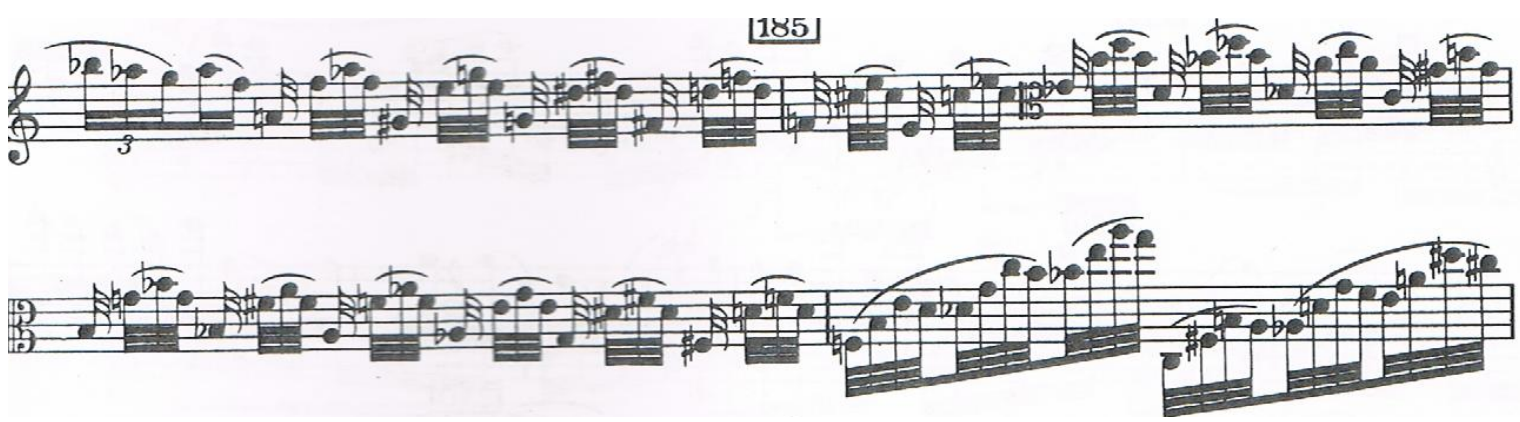

The fourth movement completes the circle - it is as fast and loud as the first movement. Unlike the first movement, however, the fourth consists of two contrasting elements. The first element is brisk, blending Bach-like melodic lines with jazzy syncopations and accentuated offbeat notes (see Mus. ex. 48).

Mus. ex. 48. Darius Milhaud, Concerto pour alto et orchestra, Vif, bars 215-223.

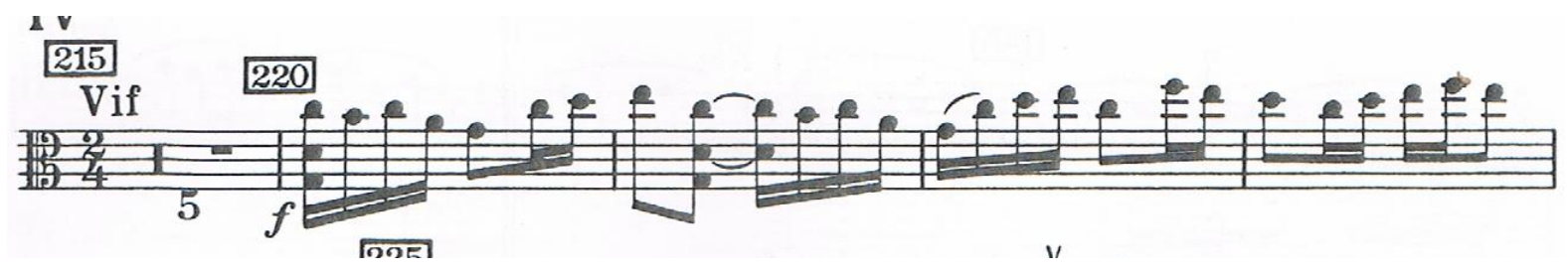

This element, although very comfortable and playable, misleads the performer and encourages a very fast speed. However, after a few bars, the first sign of further challenges arrives - a rapid passage of semiquavers complicated by string crossings and left hand fingers extensions. To avoid crossing over one string, a performer must play a sequence of four intervals of a tenth (see Mus. ex. 49a). This technique is very demanding for violinists, and normally would be avoided by composers in viola compositions. Paganini did not use the tenth in his Sonata per la Grand'Viola; however, this example is very similar to Paganini's Caprice No. 16 (see Mus. ex. 49b). 
Mus. ex. 49a. Darius Milhaud, Concerto pour alto et orchestra, Vif, bars 229-233.

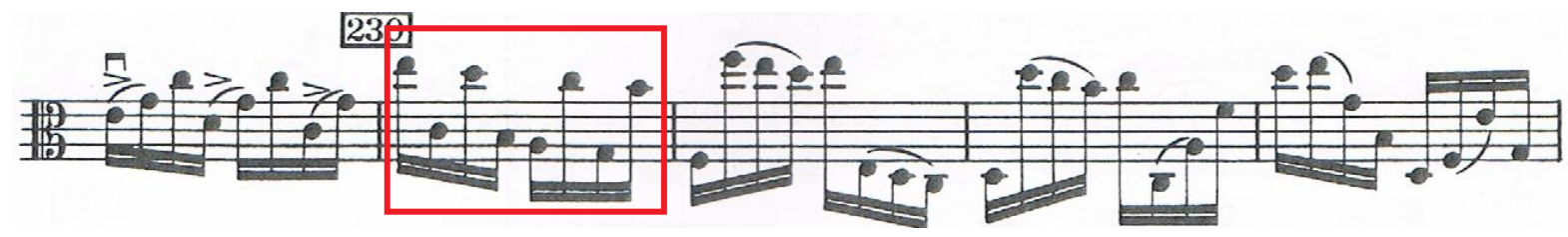

Mus. ex. 49b. Nicolò Paganini, 24 Caprices op. 1, No. 16, bars 16-18.

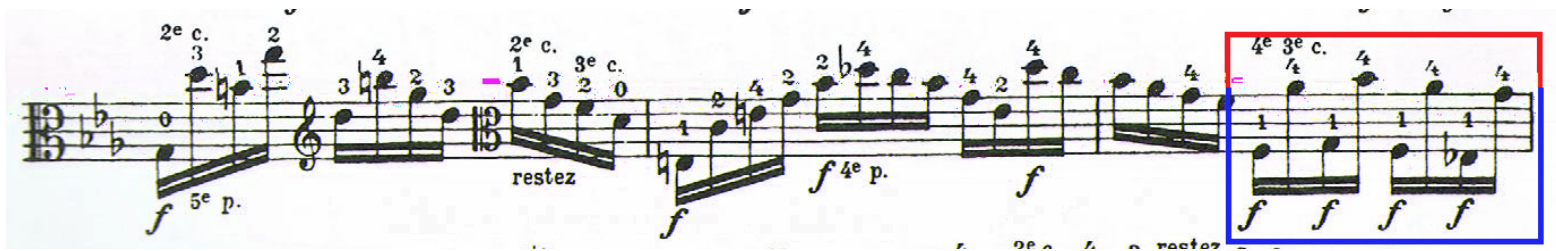

The second element is lyrical in character and bears piano dynamic (see Mus. ex. 50). This element is very short and serves as a short break for the performer before entering the recapitulation.

Mus. ex. 50. Darius Milhaud, Concerto pour alto et orchestra, Vif, bars 256-261.

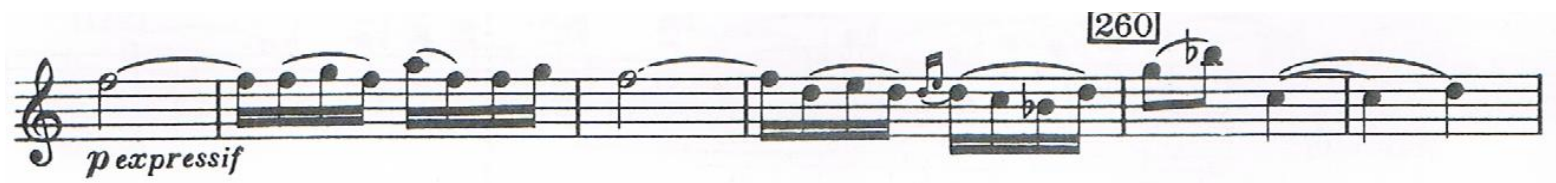

An almost exact quote from Paganini's sixteenth caprice appears in the coda (see Mus. exs. 51a and 51b).

Mus. ex. 51a Nicolò Paganini 24 Caprices op. 1, No. 16, bars 48-50.

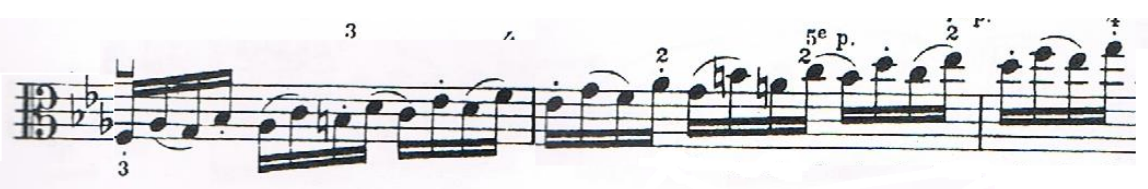




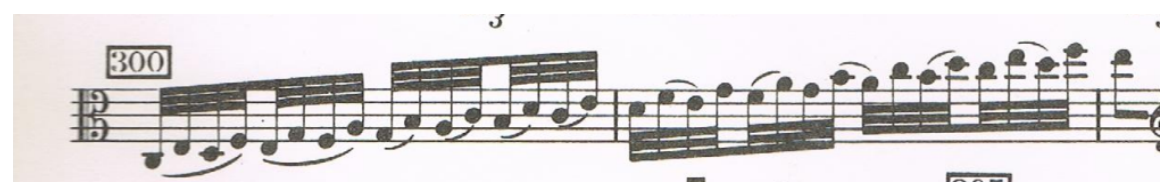

This concerto is a mixture of musical styles and quotations: Bach and jazz in the opening, and quotations from Paganini's Caprices that reveal eclecticism, a characteristic of many of Milhaud's compositions. Milhaud used a whole range of virtuoso techniques that came from his violin background. He even used techniques that Paganini avoided in his Sonata per la Grand'Viola: tenths, reversed octaves, and arpeggiato chords with a tenth between the bottom and the top notes.

\section{IIc. Darius Milhaud and William Primrose: relationship.}

Twenty-six years after Viola Concerto No. 1 was written for Paul Hindemith, another prominent violist commissioned a concerto from Milhaud. The Viola Concerto No. 2 was written for William Primrose during 1954-1955. Primrose was considered to be the 'Paganini' of the viola at this time. His arrangements of 'La Campanella', Jamaican Rumba, Paganini Caprices and other well-known pieces from the violin repertoire required a great deal of virtuoso technique. Primrose's desire for a new viola concert repertoire impressed and inspired Milhaud, who wrote the Viola Concerto No. 2 with Primrose's technical command in mind. It is technically more demanding than the Viola Concerto No. 1 and many of its difficulties arise from Milhaud's desire to explore Primrose's capabilities as a performer. The common opinion is that Milhaud's knowledge of Primrose's techniques came from their personal association and his familiarity with Primrose's own transcriptions.

During 1954 and1955, when Milhaud completed his work on the Concerto No. 2, there were plenty of exciting events in his life, including the filming of the documentary 'A Visit to Darius Milhaud'. Here is a short citation from Milhaud's autobiography 'My Happy Life' which gives us a sense of the busy life led by the composer during this period: 
A friend of mine told me that the cab-driver taking her to the Hollywood Bowl had said to her, on seeing my name in lights, "Quite a guy, that Milhaud! More than eighty years old and he works in three places at once!" Eighty was, perhaps, a slight exaggeration, but it is true that I divide my time between California, Colorado and France. ${ }^{74}$

During 1954-1955, Milhaud composed a vast amount of music including symphonies No. 6, Op. 343 and No. 7, Op. 344, Piano Concerto No. 5, Op. 346 and half a dozen other large and small pieces; this is, possibly, the reason why Milhaud 'overlooked' and did not mention the Viola Concerto No.2 in his memoirs. Neither did Primrose pay much attention to Milhaud's concerto in his autobiography 'Walk on the North Side - Memories of Violist': 'I commissioned other concertos by Fricker, Edmund Rubbra, and Milhaud (his second). ${ }^{75}$

Another brief acknowledgement of this concerto by Primrose can be found in Dalton's 'Playing The Viola'. Answering Dalton's question of '... which concertos you consider to be the most difficult to perform from a technical standpoint?" Primrose replied. ' The Second Milhaud Concerto, which I commissioned and is now seldom played, is certainly strenuous because the viola part goes on without surcease.' He also mentioned that 'Milhaud presents inordinate demands' ${ }^{76}$

Letters in the Primrose International Viola Archive (PIVA) contain information about communications between Milhaud and Primrose regarding the second viola concerto:

\section{Letter 12.2.20 - 1979, to Nathan Waks from Primrose:}

Primrose mentions that he has commissioned concerti by Milhaud and others, but gives no details about the work.

\section{Letter 14.9.9 - January 6, 1980, to Bernard Zaslav from Primrose:}

Primrose mentions that he has made corrections to Milhaud's piece with "Darius's" approval. He explains that he has not yet recorded the work but would like to have the privilege of showing the amendments someday.

\footnotetext{
${ }^{74}$ Darius Milhaud, My Happy Life, an autobiography, translated from French by Donald Evans, George Hall and Christopher Palmer (London, New York: Marion Boyars, 1995), p.229.

${ }^{75}$ Primrose, Walk on the North Side. Memories of Violist, p.188.

${ }^{76}$ Dalton, Playing The Viola, Conversations with William Primrose, p.26.
} 


\section{Letter 11.4.9 - October 20, 1979, to Maurice Riley from Primrose:}

Milhaud's second concerto is, according to Primrose, 'the most outrageously difficult work I ever tackled, and for all the immense labour I devoted to it never appealed to the public.' Primrose mentions going to Mills College to go through it, and upon seeing it he called Milhaud and explained how difficult it was. Milhaud's response was, 'Mon Cher, all concertos should be difficult.'

This position of Milhaud towards the difficulties in the music was confirmed by the composer's widow Madeleine Milhaud in one of her interviews: '...Milhaud wrote the concerto, which is more difficult than the first, but because Primrose was a very good player.... why not ask him to do the difficult things that Darius wrote. As long as you are a virtuoso, you are supposed to play that. ${ }^{77}$

Kenneth Martinson, a world expert on Milhaud's viola works, gives an appraisal of this concerto in one of his articles:

This work, hands down, is the most difficult viola concerto ever written. Milhaud wrote this [Concerto N.2] for Primrose while they were both colleagues at the Aspen Music Festival. Milhaud probably figured since Primrose was known to be the best violist of his time, that there would be no limit on how far he could stretch the violist's technique in this piece. ${ }^{78}$

\footnotetext{
${ }^{77}$ Kenneth Martinson, Interview with Madeleine Milhaud, available from www.nigun.info/f-milhaud.html (accessed 04/05/2011).

${ }^{78}$ Kenneth Martinson http://kennethmartinson.com/pdf/review_column_12.pdf (accessed 04/05/2011).
} 


\section{IId. Darius Milhaud. Viola Concerto No. 2, Op. 340 (1954-1955) dedicated to William Primrose.}

During my initial enquiries, I discovered that some limited information about this concerto and sources related to it are available. With the help of Professor Claudine Bigelow ${ }^{79}$, I was fortunate to obtain the digital copy of the manuscript of the score of this concerto, which is kept at the Primrose International Viola Archive (PIVA) ${ }^{80}$ based at Brigham Young University in Provo, Utah, USA. As I discovered later, this score has never been printed and is available for hire only in the form of the hand-written copy (see Mus. ex. 52). I also found that the recording of the premiere performance of this concerto with William Primrose and WDR Symphony Orchestra Cologne under the baton of Hans Rosbaud, recorded on November 27 1958, was available from the Contraclassics website ${ }^{81}$. Having this recording was an enormous help when I was learning the concerto. However, the most valuable discovery for me was the score of the piano reduction of this concerto, with the working markings and remarks in the hand of William Primrose (see Mus. ex. 53).

\footnotetext{
$79 \mathrm{Dr}$. Claudine Bigelow is head of viola studies and chamber music coordinator at the Brigham Young University School of Music located in Provo, Utah http://home.byu.edu/home/search?search=Claudine+Bigelow \&x=14\&y=22 (accessed 04/05/2011)

${ }^{80}$ The Primrose International Viola Archive. http://americanviolasociety.org/education/piva/accessed (accessed 27 February 2013)

${ }^{81}$ Darius Milhaud, Concerto No.2 for Viola and Orchestra. William Primrose, Hans Rosbaud, and WDR Symphony Orchestra Cologne. Recorded on November 27, 1958. Available from www.contraclassics.com/browser/recording:2876 (accessed 01 July 2013)
} 
Mus. ex. 52. Darius Milhaud. Deuxiéme Concerto pour Alto et Orchestre, a William Primrose, title page in Milhaud's hand. ${ }^{82}$

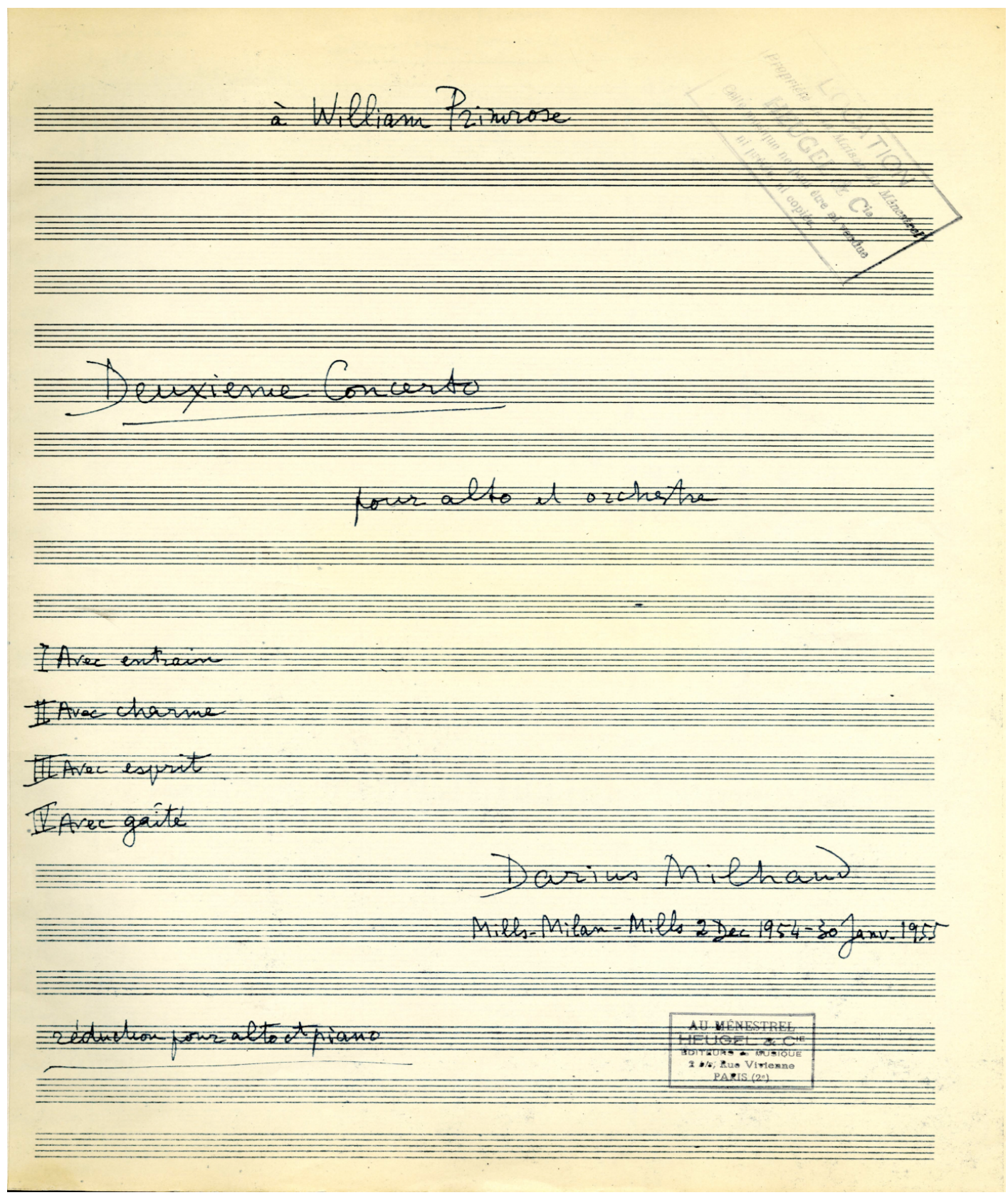

82 Darius Milhaud Deuxiéme Concerto pour alto et orchestra, A William Primrose, the manuscript of the score, available from William Primrose archive (PIVA) at the Brigham Young University in Utah, USA. 
Mus. ex. 53. Darius Milhaud, Deuxiéme Concerto pour Alto et Orchestre, a William

Primrose. The manuscript of the piano reduction is in the hand of Darius Milhaud with Primrose's fingering and other marks. ${ }^{83}$

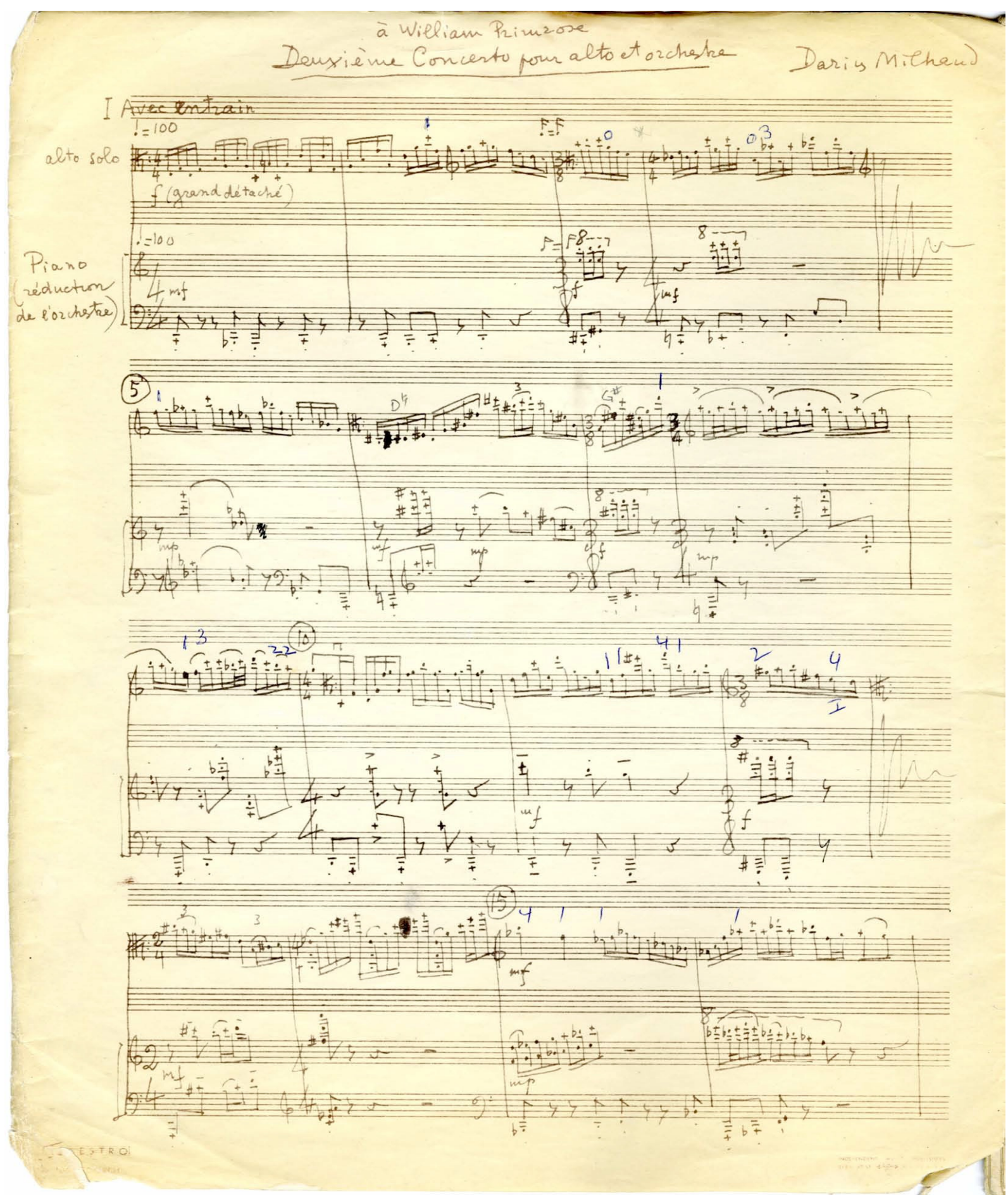

${ }^{83}$ Some musical examples from this work is taken from the manuscript of the piano reduction which is kept in the William Primrose archive (PIVA) at the Brigham Young University in Utah, USA: Darius Milhaud, Deuxiéme Concerto pour alto et orchestra. A William Primrose. 
Having this manuscript while learning the concerto was an advantage; to be able to compare my own findings of the appropriate fingering and bowing with those of Primrose's was a great help and encouraged me in various ways. I discovered that I was thinking in a very similar way to Primrose with regards to fingering - I was working on my own solutions before checking them with Primrose's markings. Nevertheless, I was disappointed to discover that some of the most difficult places were left unmarked. I must admit, I had very different ideas about bowing, which displayed differences in the perception of the music rather than the technical approach.

Milhaud's interpretation of the term concerto is the combination of the Latin words conserere (to tie, to join, to weave) and certamen (competition). The viola part is a 'thread' which is tying the orchestral part together by interweaving the short, hardly apprehensible motifs played by the various groups of instruments into a wondrously complex structure, where the competing of the soloist and the orchestra is secondary, and only possible, when they are tied and joined together.

Similar to the First viola concerto, Concerto No.2 comprises four movements. This is a reference to the baroque style of the concerto rather than the classical form that comprises three movements. However, the baroque concerto was intended to have two slow movements in the order: slow-fast-slow-fast. In Milhaud's interpretation, there are three fast movements - first, third and fourth, and a slow second movement:

$1^{\text {st }}$ movement: Avec Entrain (crotchet equals 100) - fast

$2^{\text {nd }}$ movement: Avec Charme (quaver equals 104) - slow

$3^{\text {rd }}$ movement: Avec Esprit (crotchet equals 108) - fast

$4^{\text {th }}$ movement: Avec gaité (dotted crotchet equals 112) - fast

I intentionally underlined the slow movement, as it is very hard to distinguish the difference between the fast and the slow movements relying on figures. While learning the concerto, I treated the slow movement as an opportunity to recuperate between the first and second movements, which are both very demanding physically and intense emotionally. I was amused to discover that the slow movement would give me no chance to have a much-desired rest if I chose to play it in the tempo where a dotted crotchet equals 104. At the beginning of my journey I tried to question the tempos indicated in the score, only to 
discover that the longer I was playing this concerto, the more I agreed with the composer and his choice of speed.

The first movement, with the character marking 'Avec Entrain' (with input), can be described as a neoclassical one and it is mechanical and industrial in its character. The relationships between the soloist and the orchestra in this movement is reminiscent of a relationship between two strangers who are 'getting used to' each other's presence and trying to work out their liking or disliking of each other. There is no open conflict between the soloist and the orchestra, but there is also very little support for each other. The main requirement for the orchestra is precise and accurate counting and execution of the dynamic markings that are carefully selected by the composer for the obvious reason of exposing the solo viola. This movement is written in the classic sonata form. The composer omitted an orchestral exposition and the movement begins with the busy main theme in the solo viola part. This theme is characterised by the contradicting markings of grand detaché bow stroke in the solo viola part and staccato in the accompaniment, which is setting up the mode of the first encounter between the soloist and the orchestra (see Mus. ex. 54).

Mus. ex. 54. Darius Milhaud, Deuxiéme Concerto pour Alto et Orchestre, $1^{\text {st }}$ movement, bars $1-3^{84}$
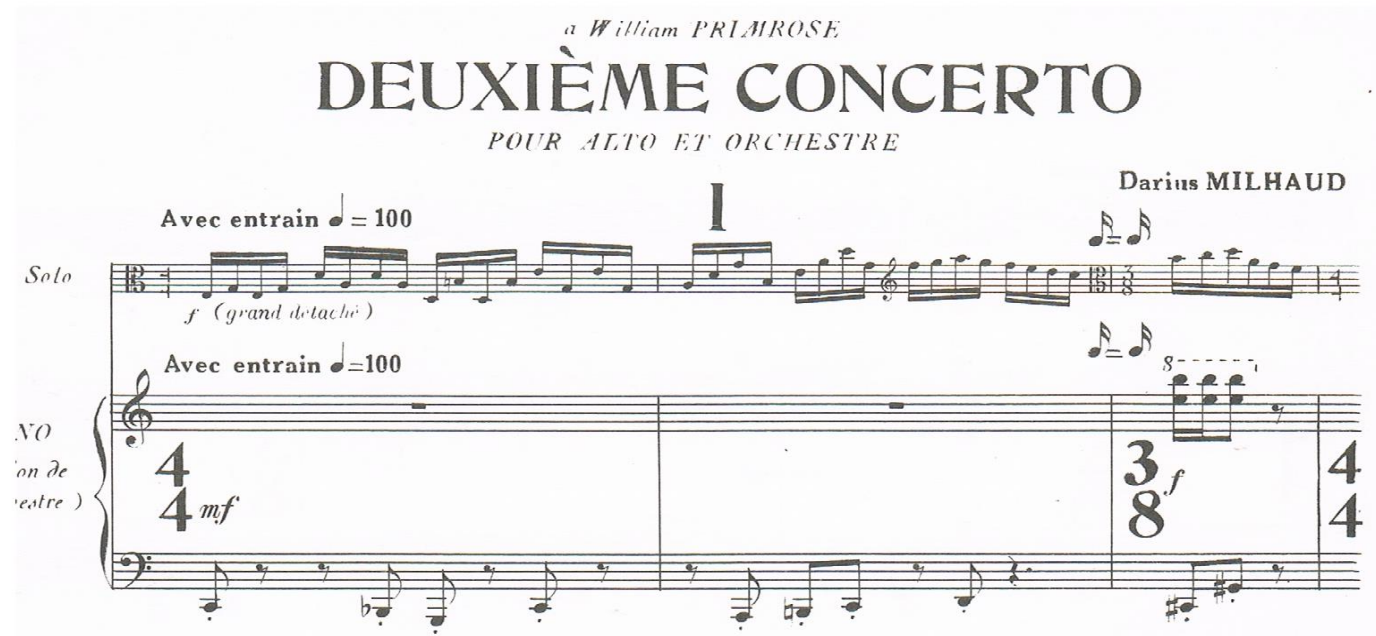

One of the distinct features of the main theme is the changeable metro-rhythm; within 16 bars of the theme, the metre changes 8 times. The two 4/4 bars of semiquavers are followed by one $3 / 8$ bar, and the next three bars of semiquavers are in $4 / 4$ time

\footnotetext{
${ }^{84}$ Some musical examples from this work are taken from Heugel's edition: Darius Milhaud, Deuxiéme Concerto Pour Alto et Orchestre piano reduction, (Paris: Heugel et Cie, 1958).
} 
signature. This is followed by another $3 / 8$ bar which leads to the two $3 / 4$ bars, and the two 4/4 bars are followed by a $3 / 8$ bar, and the theme finishes with two $2 / 4$ bars. This trick allowed Milhaud to achieve a sense of the endless mechanical flow of the theme.

The character of the solo part is aggressive and continuous with forte dynamic throughout the theme. In contrast, the orchestral part comprises short motifs, uncertain in their syncopated nature, and staccato. At the climax of the first theme, the viola is left unaccompanied with a technically challenging sequence of chords and ascending arpeggios (see Mus. ex. 55).

Mus. ex. 55. Darius Milhaud, Deuxiéme Concerto pour Alto et Orchestre, $1^{\text {st }}$ movement, bars 13-15.

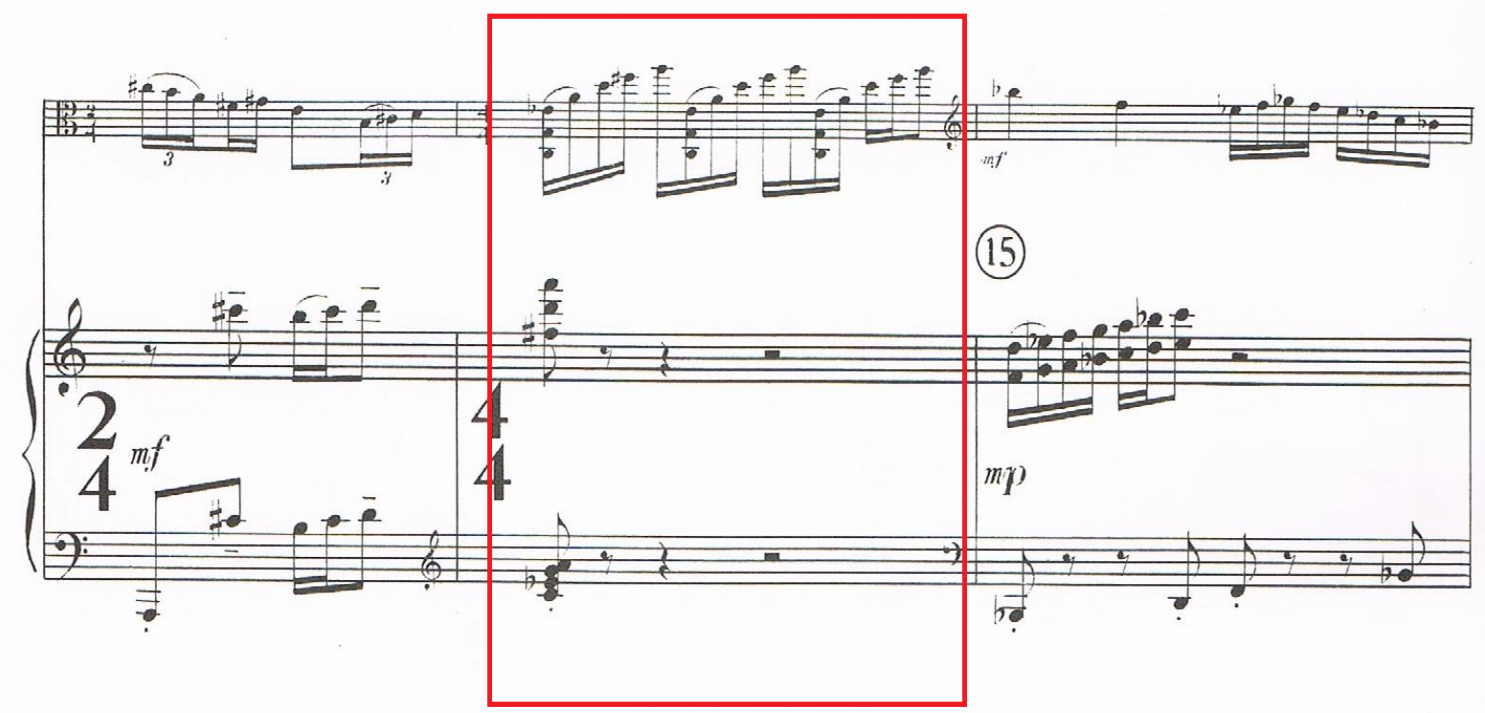

The technical challenges of the theme are endless: from the physicality of the grand detaché bow stroke to the inconvenient shifts, rapid string crossings, high positions and the high pressure of maintaining forte dynamic throughout a good half of the first page.

There were not many discrepancies between my approach and Primrose's markings in the main theme. I would like to mention two cases of different bowing which could potentially show a contrasting understanding of the music.

The first example is in the lead up to the climax of the first theme. I made the decision to join the fourth semiquaver of bar 9 to the previous slur, as I wanted the first note of bar 10 to be played by up bow. The reason was to not emphasise the gap between the first and 
second notes of bar 10, which naturally occurs with the string crossing. My idea was to encourage the continuous flow of the melody until the climax, where I thought it was appropriate to have a slight ritardando in bar 14 and a comma between bars 14 and 15 (see Mus. ex. 56a). In contrast, Primrose chose to play both the first and second notes by down bow - 'restarting' the theme on the lead up to the climax, and continuing through without slowing down (see Mus. ex. 56b).

Mus. ex. 56a. Darius Milhaud, Deuxiéme Concerto pour Alto et Orchestre, $1^{\text {st }}$ movement, bars 7-15.

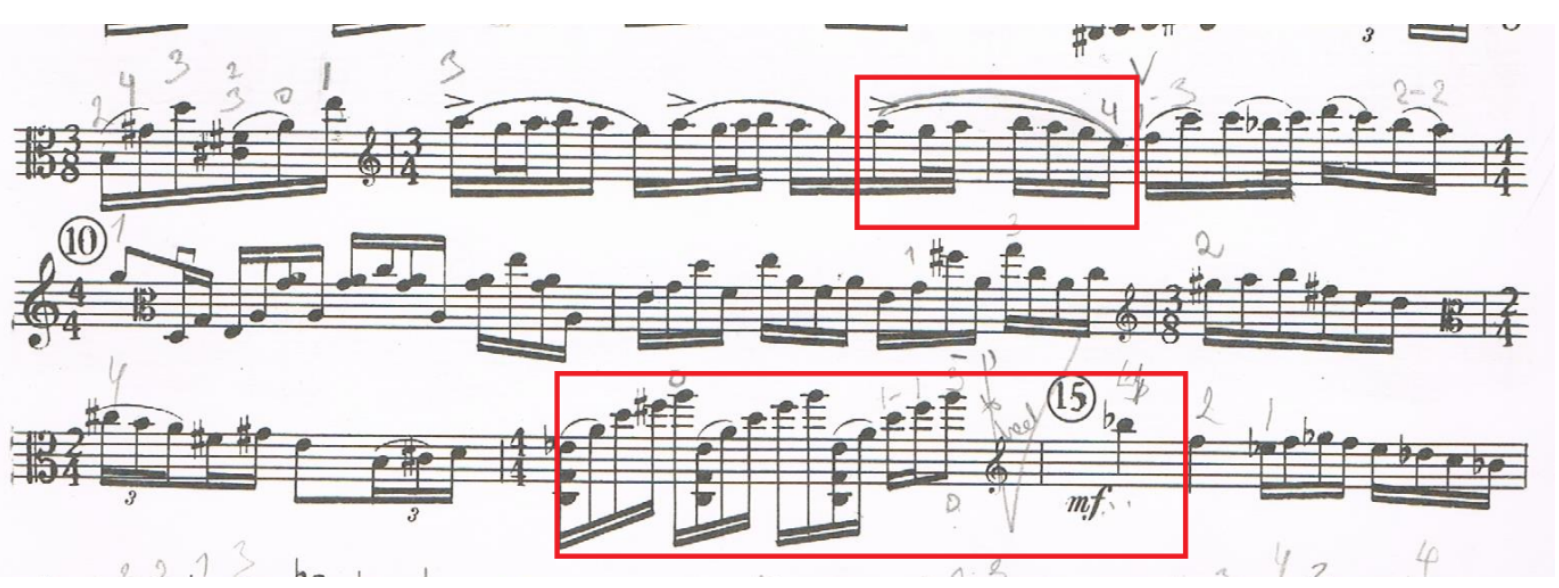


Mus. ex. 56b. Milhaud, Darius. Deuxiéme Concerto pour Alto et Orchestre, manuscript, $1^{\text {st }}$ movement, bars 9-16

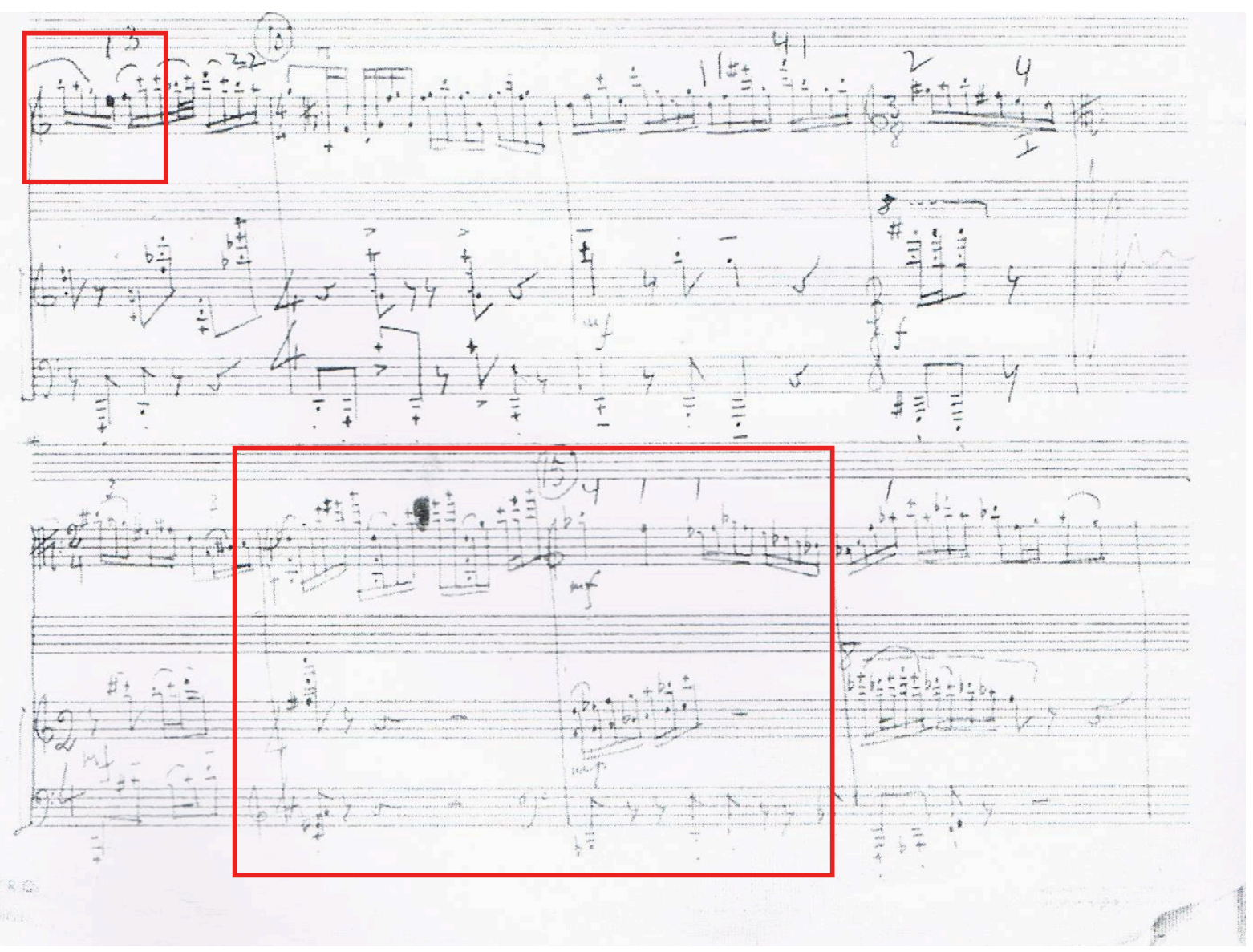

By making this comparison, I do not question which interpretation is right -- I am just making an observation of the differences of opinions. My performance supervisor Professor Martin Riseley supported my version ${ }^{85}$. During rehearsals with the orchestra, the conductor, Kenneth Young, ${ }^{86}$ encouraged me to make even bigger ritardando and the comma, in an attempt to create better communication and understanding with the orchestra.

A very short transition connects the main theme with the second theme of this movement, which is lyrical and contrasts with the first theme with softer dynamics. Milhaud introduced one of his favourite technical elements in this theme - harmonics. (See Mus ex. 57)

\footnotetext{
${ }^{85}$ Martin Riseley, Associate Professor, MusB Cant, MM DMA Juilliard, Associate Director, Head of Strings, Orchestra Coordinator - Violin. http://www.nzsm.ac.nz/about-us/our-people/staff-profile/?staff=122791. ${ }^{86}$ Kenneth Young, member of the music faculty of the New Zealand School of Music at Victoria University Wellington, where he lectures in conducting and orchestration, composition and arrangement. http://www.nzsm.ac.nz/about-us/our-people/staff-profile/?staff=124367.
} 
Mus. ex. 57. Darius Milhaud, Deuxiéme Concerto pour Alto et Orchestre, $1^{\text {st }}$ movement, bars 25-28.

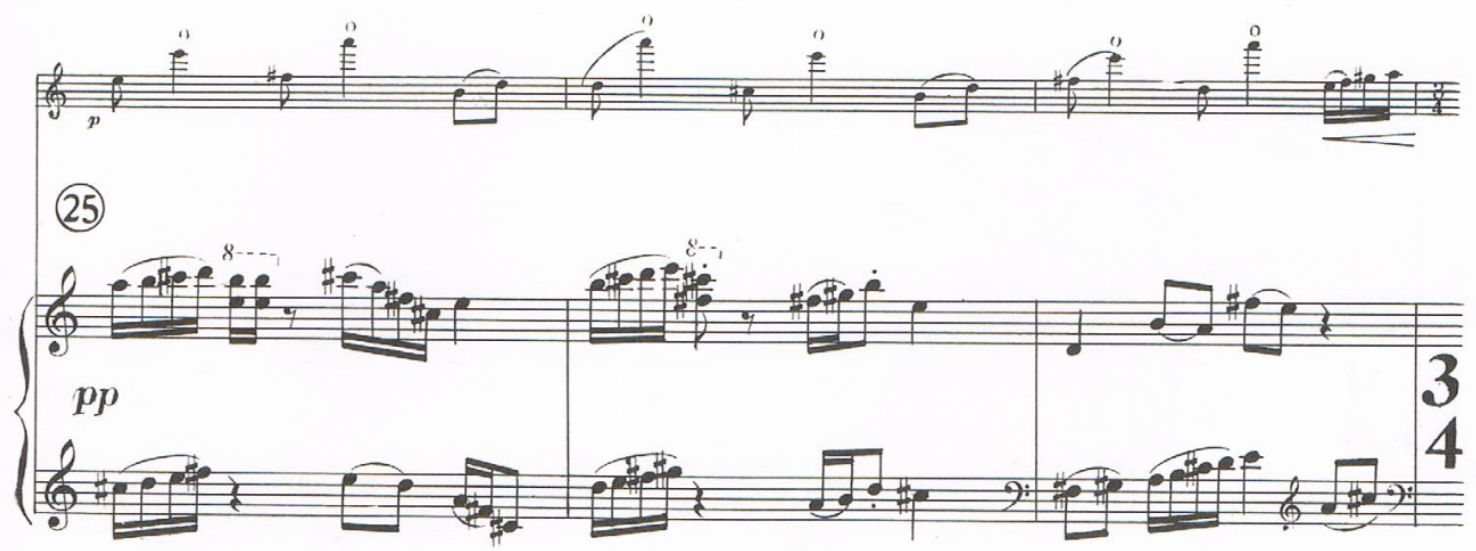

11.:315!98

The conclusion of the second theme is a string of technical challenges: sequences of arpeggios featuring double stops in thirds are followed by a string crossing 'exercise' - a bar which could be played on one or two strings, bearing the author's remark sur 3 cordes (on three strings). This request makes it artificially difficult. This bar sparked a discussion about an intentional overcomplicating of the solo part (see Mus. ex. 58).

Mus. ex. 58. Darius Milhaud, Deuxiéme Concerto pour Alto et Orchestre, $1^{\text {st }}$ movement, bars 30-32.

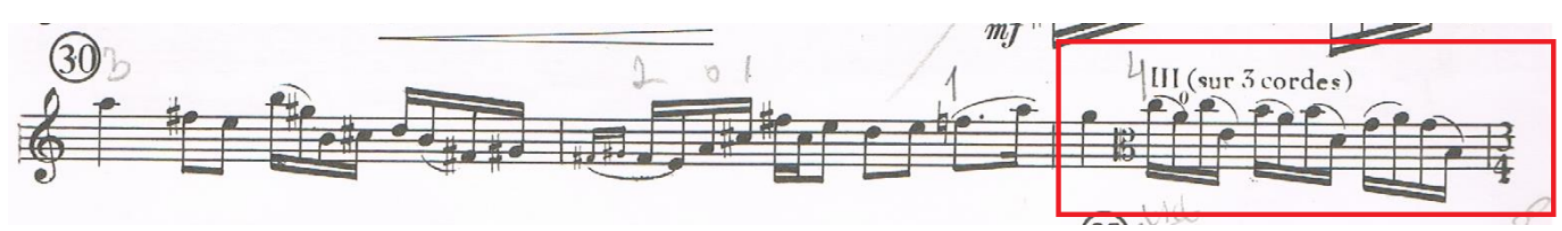

I followed the composer's request, but could not find a logical explanation for this marking. There was no significant impact on the musical value that could possibly be made by simplifying this element. There was no fingering suggested by Primrose in this case.

The exposition is concluded with a set of double stops, which are leading to the passage in C major.

The first theme returns in the development with a different dynamic - mezzo piano and spiccato bow stroke (see Mus. ex. 59). The structure of the main theme is more stable in the development than in the exposition in terms of changeable metro-rhythm. Similar to 
the exposition, the main theme is comprised of 16 bars: three bars $4 / 4$ of semiquavers ascending from the $C$ string to the higher positions on the $A$ string, followed by a $3 / 8$ bar; 
$\mathrm{G}$ string. This would make it impossible to play the middle note of the chord $-\mathrm{G}$. It is possible to play this $\mathrm{G}$ note on the $\mathrm{C}$ string, but then it would eliminate the lower note $-E$, which can only be played on the $\mathrm{C}$ string. This is an almost un-playable concoction and I assume it was adjusted by Primrose.

Mus. ex. 61. Darius Milhaud, Deuxiéme Concerto pour Alto et Orchestre, $1^{\text {st }}$ movement, bar 47.

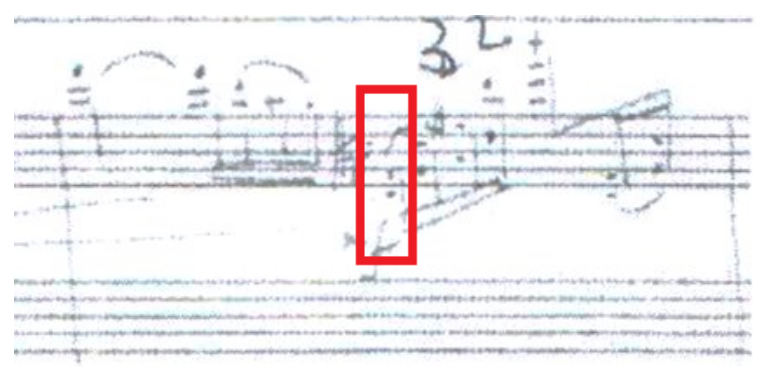

The second theme is more developed in this section. Bearing the same dynamic marking as in the exposition, this time it is covering the entire range of the viola - starting in the low register on the $G$ string and gradually progressing to the $6^{\text {th }}$ position on the $A$ string and forte. This lyrical tune is disturbed by the rapid sequences of double stops reminiscent of those from the main theme (see Mus. ex. 62).

Mus. ex. 62. Darius Milhaud, Deuxiéme Concerto pour Alto et Orchestre, $1^{\text {st }}$ movement, bars 54-61.

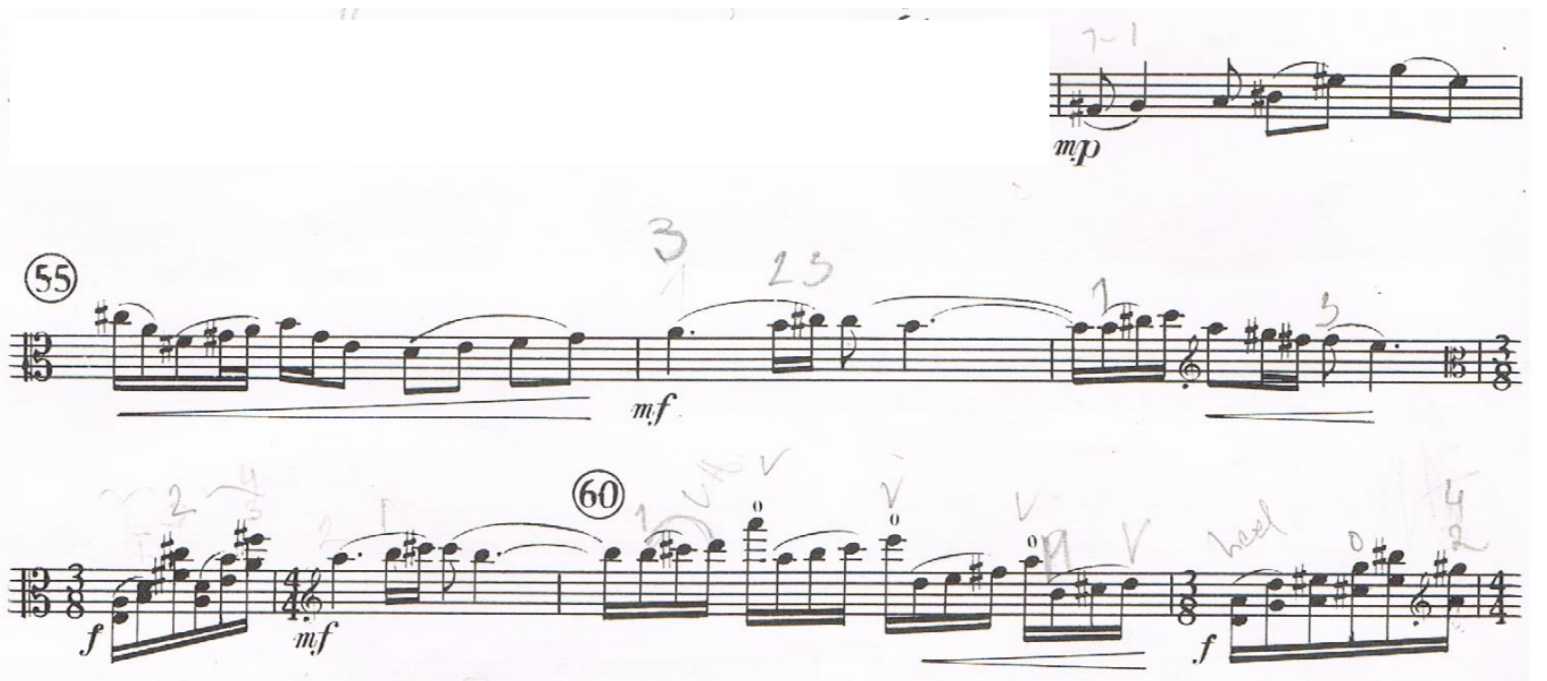


These short runs comprise double stops that are getting progressively more difficult. I found that the majority of my practice time was consumed by learning these passages. In one of the cases, the main challenge was a usage of the same finger for three subsequent double stops (see Mus. ex. 63).

Mus. ex. 63. Darius Milhaud, Deuxiéme Concerto pour Alto et Orchestre, $1^{\text {st }}$ movement, bar 58.

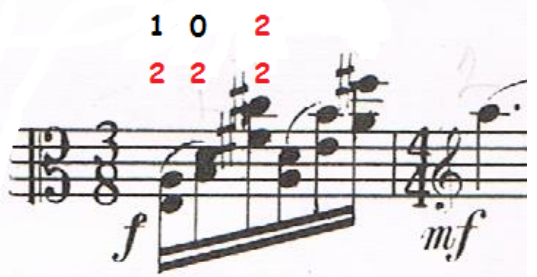

In the next case, four from six intervals are fifth, which makes it challenging in terms of intonation (see Mus. ex. 64).

Mus. ex. 64. Darius Milhaud, Deuxiéme Concerto pour Alto et Orchestre, $1^{\text {st }}$ movement, bar 61.

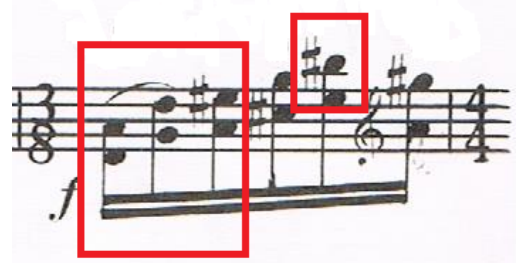

The following example is complicated by a three-note chord in the middle of the passage (see Mus. ex. 65).

Mus. ex. 65. Darius Milhaud, Deuxiéme Concerto pour Alto et Orchestre, $1^{\text {st }}$ movement, bar 66.

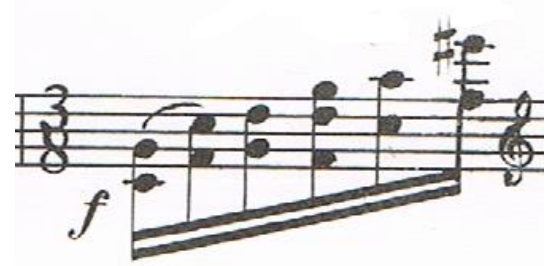


The last set of the double stops from the second theme is highly uncomfortable, as it contains two technical challenges: the necessity of transferring the first finger across three strings within the first three double stops, and the string crossing (see Mus. ex. 66).

Mus. ex. 66. Darius Milhaud, Deuxiéme Concerto pour Alto et Orchestre, $1^{\text {st }}$ movement, bar 69.

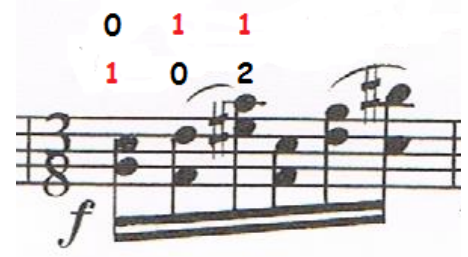

Between the troublesome patches of double stops, the modified second theme is lyrical and highlights the beauty of the upper register of the viola. However, it is not devoid of technical pitfalls. Two very similar sequences of semiquavers encrusted with harmonics add an extra challenge. This is a transformation of the harmonics of the second theme from the exposition (see Mus. ex. 67).

Mus. ex. 67. Darius Milhaud, Deuxiéme Concerto pour Alto et Orchestre, $1^{\text {st }}$ movement, bars $59-60$.

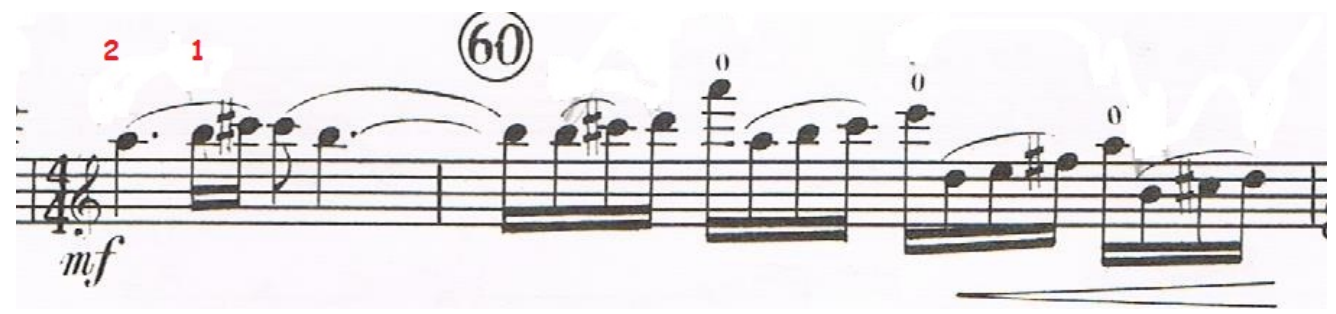

The challenge of this example is in the very high position and unsecured shifts backwards after each harmonic. To play it in the required tempo one must work on a very quick and precise set of shifts. The next example brings more challenge with the execution of the harmonics (see Mus. ex. 68). 
Mus. ex. 68. Darius Milhaud, Deuxiéme Concerto pour Alto et Orchestre, $1^{\text {st }}$ movement, bar 65.

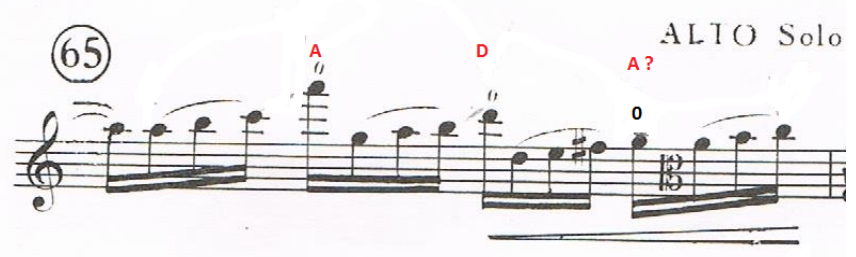

During the first reading, it was suggested by Professor Riseley that I should check the last harmonic of this bar with the score. In the order of appearance of harmonics A-D-G, it would be logical to have the last note in this chain as an A. It also would be much easier to execute this note. Perhaps there was a misprint and the alto clef should have appeared one note earlier - before the last four semiquavers? However, by checking both the available manuscripts I confirmed that the alto clef is positioned at the same place in the piano reduction. In this case, Primrose's markings of the placement of the alto clef and harmonics are exactly the same as the printed version (see Mus. ex. 69a). In the orchestral score the alto clef has been moved even further, and appears at the end of bar 65 (See Mus. Ex. 69b)'

Mus. ex. 69a. Darius Milhaud, Deuxiéme Concerto pour Alto et Orchestre, $1^{\text {st }}$ movement, bar 65.

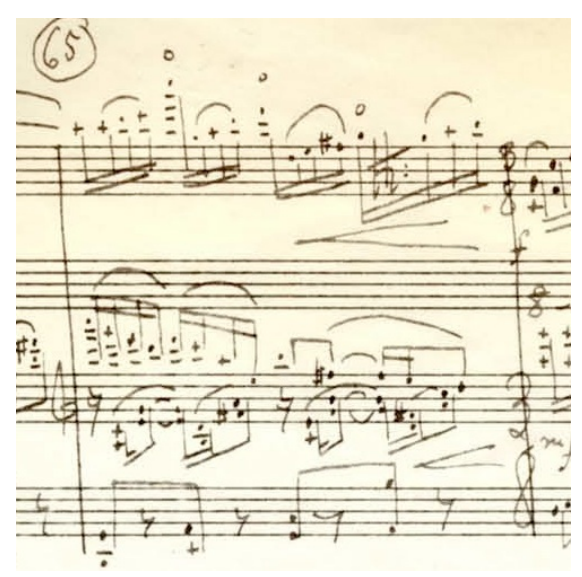


Mus. ex. 69b. Darius Milhaud, Deuxiéme Concerto pour Alto et Orchestre, $1^{\text {st }}$ movement, bar 65.

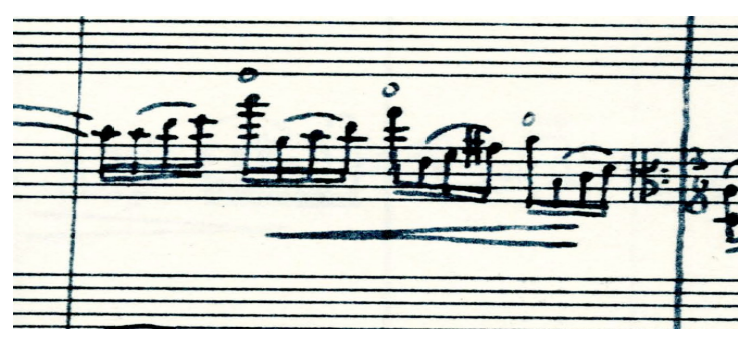

Both themes return once again and lead to the recapitulation, where the main theme from the exposition appears in the same key, but starts one tone higher than in the exposition. In the coda, the main theme is repeated with very slight changes and the movement finishes in the key of $\mathrm{C}$ major.

The second movement bears the character indication 'Avec charme' (charming) alongside the $6 / 8$ time signature and the overbearing amount of the demisemiquavers misleadingly suggests a slow tempo. However, the tempo indication is quaver equals 104 . This is a very hard requirement for a violist. I felt that Milhaud was trying to 'impersonate' some 'light touch' violin playing with a very high register, very fast finger work and soft dynamics. The theme is very simple and charming. The repetitiveness of the motif is accentuating its simplicity (see Mus. ex. 70).

Mus. ex. 70. Darius Milhaud, Deuxiéme Concerto pour Alto et Orchestre, $2^{\text {nd }}$ movement, bars 1-8.
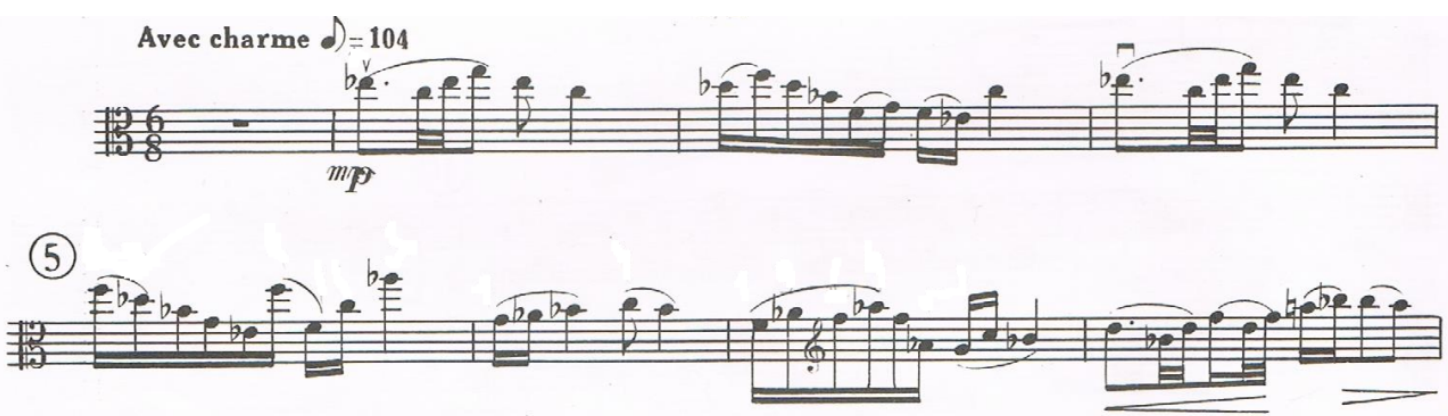

The character of the theme is dictating the 'violinistic' approach to the technical elements. High positions prevail throughout the movement, and the theme, which could be easily played on the E string on a violin, requires tremendous knowledge of the high 
positions and advanced shifting techniques. Perhaps one of the most uncomfortable places of this movement is in the development section - the conclusion of the main theme in bar 43 (see Mus. Ex. 71).

Mus. ex. 71. Darius Milhaud, Deuxiéme Concerto pour Alto et Orchestre, $2^{\text {nd }}$ movement, bars 41-43.

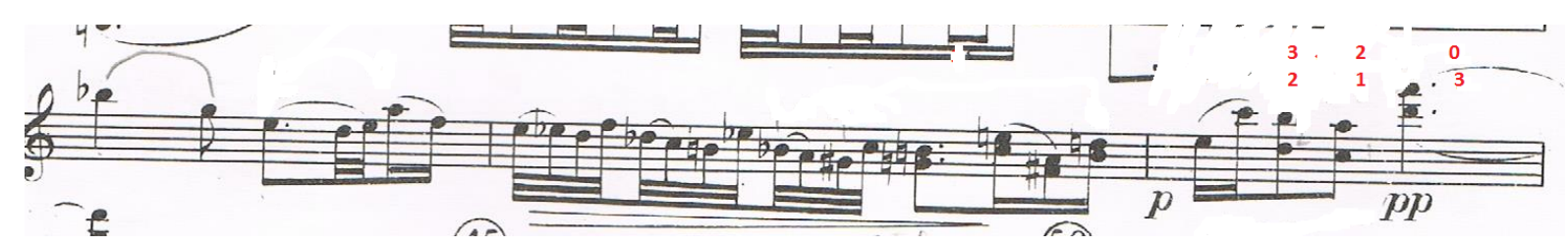

The phrase concludes in the pianissimo with the shift from the double stop in the second position to the harmonic double stop fifth in the eleventh position. Fifth is a difficult interval to execute on the violin, and of course it is even more challenging on the viola, due to the wider fingerboard strings on the viola that are further apart from one another. The pianissimo in this case is an extra challenge. It requires precision in the coordination of the speed of the bow with the pressure applied on the bow, and its position on the strings between the bridge and the fingerboard. An extra challenge of this bar is in executing the precise intonation - the solo viola's fifth $D$ and $A$ is placed against the fifth $B$ and $F$ sharp played by the flutes.

In the next example, Milhaud used the technique that is commonly found in Paganini's Caprices, an execution of the harmonic by the expansion of the left hand fingers to the interval of fifth on the same string (see Mus. ex. 72). This bar is a very awkward transition between the two themes. The harmonics are followed by an arpeggio, which covers three octaves.

Mus. ex. 72. Darius Milhaud, Deuxiéme Concerto pour Alto et Orchestre, $2^{\text {nd }}$ movement, bar 57.

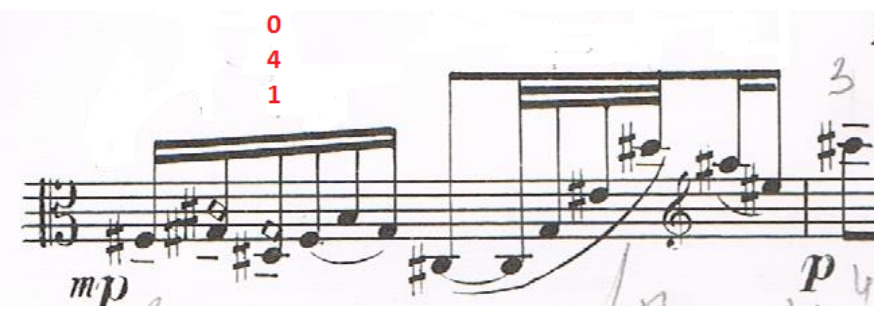


By using harmonics, Milhaud created a very interesting echo effect. The F major arpeggio is played in the ordinary notes, and repeated in the harmonics (see Mus. ex. 73).

Mus. ex. 73. Darius Milhaud, Deuxiéme Concerto pour Alto et Orchestre, $2^{\text {nd }}$ movement, bar 67.

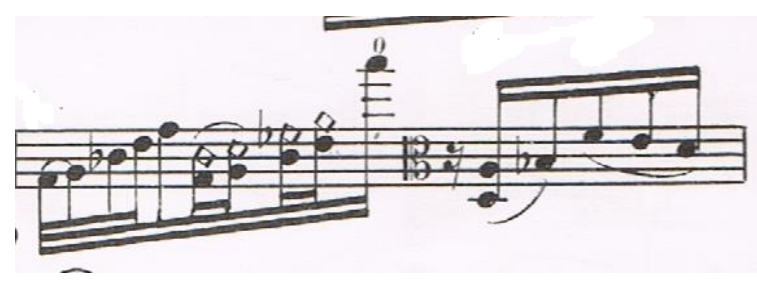

Gradually, the music progresses to the cadenza-like section, which is the most challenging part of the second movement (see Mus. ex. 74). This cadenza is primarily based on the ascending and descending arpeggios - the technique infamously used by Paganini in the caprice No.1. When compared with the aforementioned caprice, the techniques are very similar, but they are not as challenging. Milhaud excluded the fingers extension and did not use positions above the third. However, the difficulty of this cadenza lies in the usage of the contemporary harmonies and melodic lines. There is very little reward for the violist for undergoing all the technical challenges since the viola is playing an accompanying role, and Milhaud gives the theme to the orchestra. This is also the loudest part - the first time since the beginning of this movement that the composer uses the dynamic marking forte. 
Mus. ex. 74. Darius Milhaud, Deuxiéme Concerto pour Alto et Orchestre, $2^{\text {nd }}$ movement, bars 74-87.

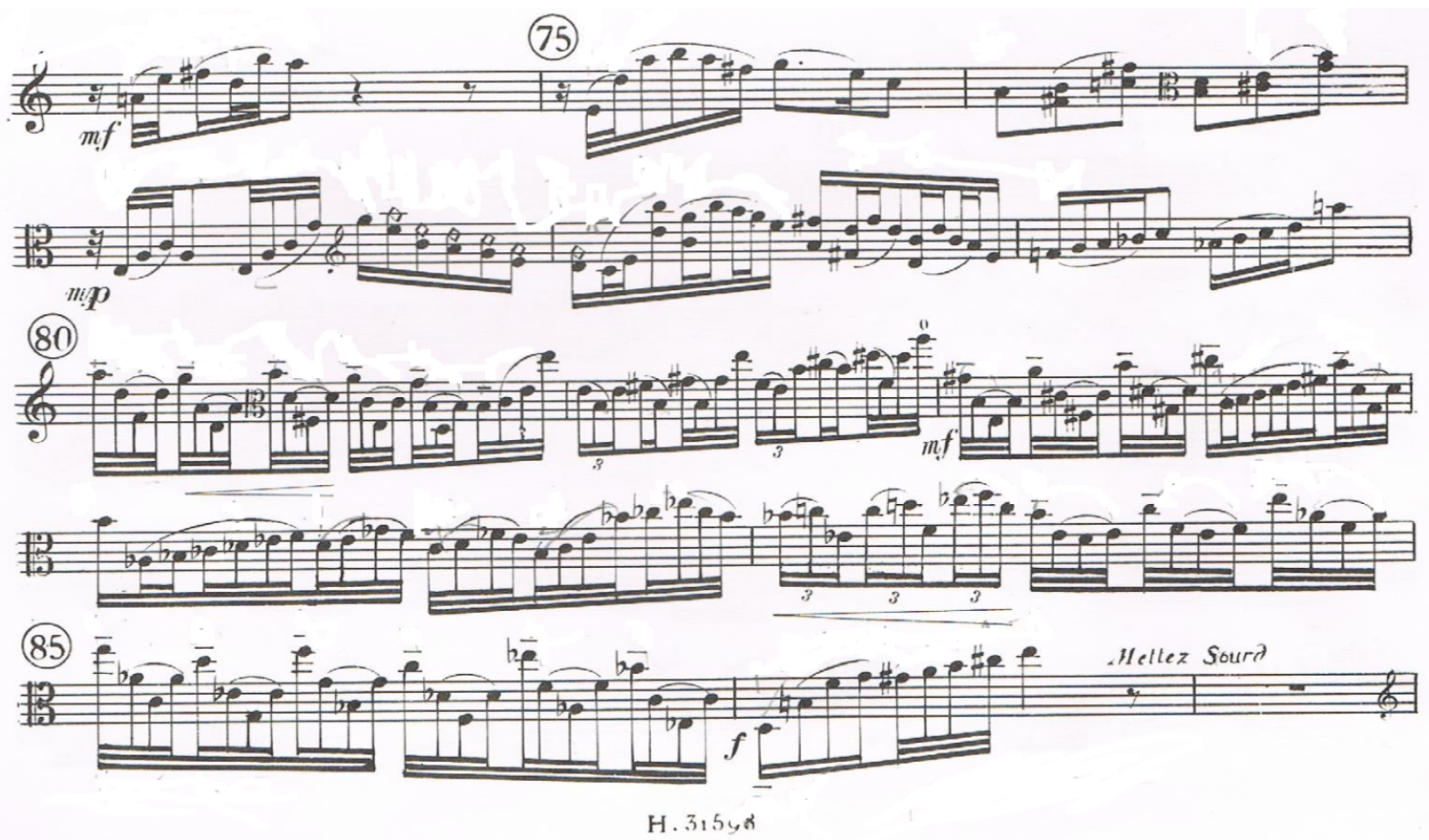

The return of the main theme with its simplicity and soft dynamic creates an enormous contrast to the previous section. The movement finishes in the pianissimo with the viola left unaccompanied in the last bar.

Avec esprit (with spirit) is the character indication of the third movement, which brings back the mechanical and aggressive spirit of the first movement. The best way to describe the music of this movement would be to compare it with the kaleidoscope of techniques derived from both Paganini's and Hindemith's music. Just under five minutes long, this movement is 'packed' with highly demanding virtuoso techniques. Looking at the manuscript of the piano reduction with Primrose's markings, one can infer that he also found this movement difficult. The markings are more frequent, and often Primrose uses a different coloured pencil to highlight important or especially uncomfortable places.

The movement opens with the orchestral exposition, for which Milhaud generously allocated twenty bars. The viola does not join in; it attacks the orchestra with its entrance in the high register and an intense forte dynamic. During one of the sessions, Professor Riseley compared the opening of this movement with the $16^{\text {th }}$ caprice by Paganini. Of course he was not talking about the music, but the bow stroke that is very similar to the one that should be used in the aforementioned caprice. Paganini described this bow stroke as a martele. 
The next element could be identified as one of the favourite techniques used by Paul Hindemith: the ascending sequence of chords that are connected by repeated semiquavers (see Mus. ex. 75).

Mus. ex. 75. Darius Milhaud, Deuxiéme Concerto pour Alto et Orchestre, $3^{\text {rd }}$ movement, bars 42-43.

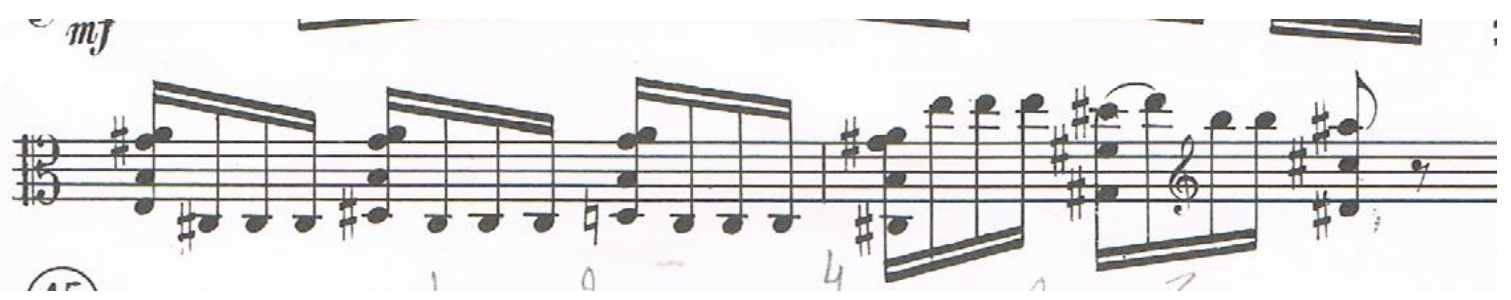

Hindemith used this technique in almost every piece he wrote for the viola: the first movement of Der Schwanendreher, the first movement of the Konzertmusik, and the sonata for solo viola Op. 25/1 (1922). Primrose circled the lower notes of the chords, which are creating a descending chromatic scale (see Mus. ex, 76).

Mus. ex. 76. Darius Milhaud, Deuxiéme Concerto pour Alto et Orchestre, $3^{\text {rd }}$ movement, bars 41-43.

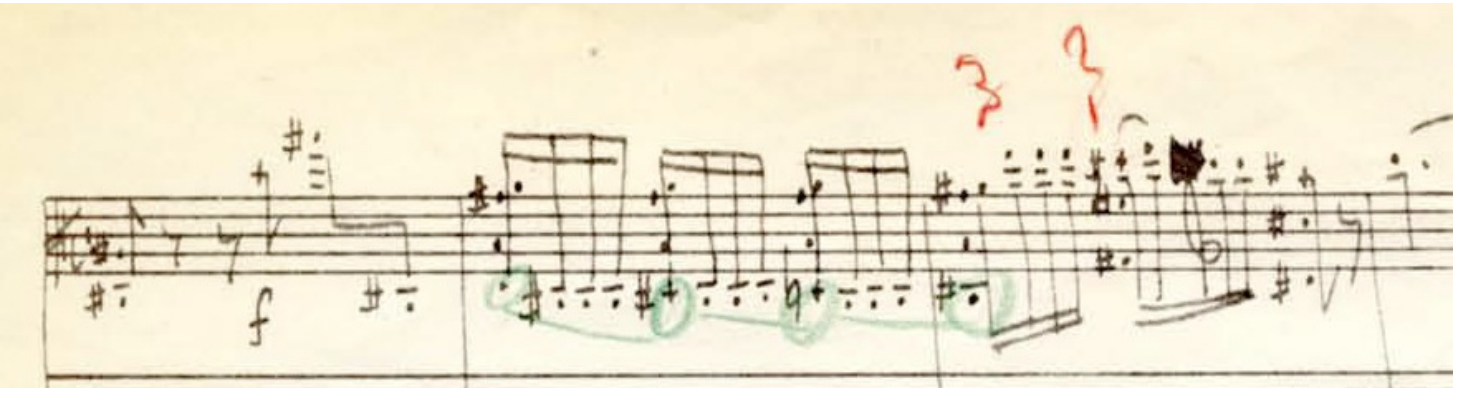

The second theme of the movement arrives as a breath of fresh air. It is not very demanding technically, and the melody is romantic and airy. Here is a chance for the performer to show off the sonorous qualities of the viola's upper register (see Mus. ex. 77). A few lines of this theme allow the soloist to have a desperately needed break before embarking on the journey through the rest of the movement. 
Mus. ex. 77. Darius Milhaud, Deuxiéme Concerto pour Alto et Orchestre, $3^{\text {rd }}$ movement, bars $59-61$.

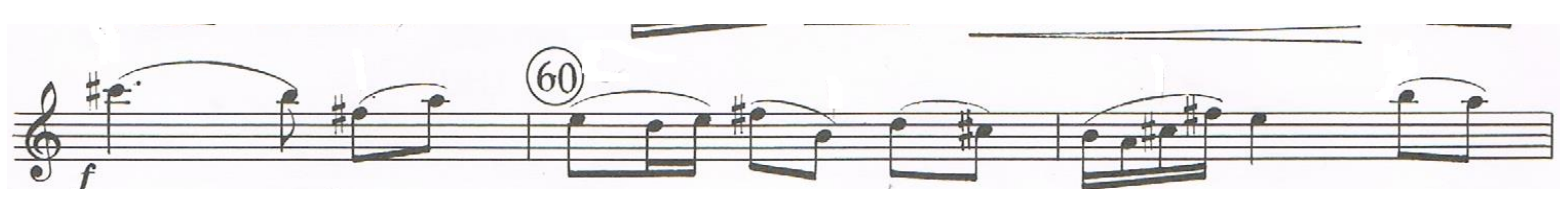

The development section is arguably one of the most difficult pieces for the viola I have ever encountered. There are techniques that are highly demanding and often very uncomfortable to execute on the viola. This is an exploration of the viola by a musician who is familiar with the instrument in theory, but not in practice. Milhaud certainly was very familiar with the range of the viola, and knew that all the double stops, chords, passages and other technical elements he used in the score are within the range of a competent violist, and they are theoretically playable. Within the next two pages there is not a single bar without a technical challenge. Here are two particularly difficult moments from this movement. The first example is the set of double stops concluding with a chord. The first challenge of this example is intonation. Once again Milhaud 'overlooked' the fact that the viola's fingerboard is wider than the violin's and it takes more time and physical effort to transfer a finger across two strings. It gets even more difficult at the end of the bar where the same motif must be played twice as fast. The shift to the fifth position for the final chord of this bar is the last challenge of this example (see Mus. ex. 78).

Mus. ex. 78. Darius Milhaud, Deuxiéme Concerto pour Alto et Orchestre, $3^{\text {rd }}$ movement, bars 86-87.

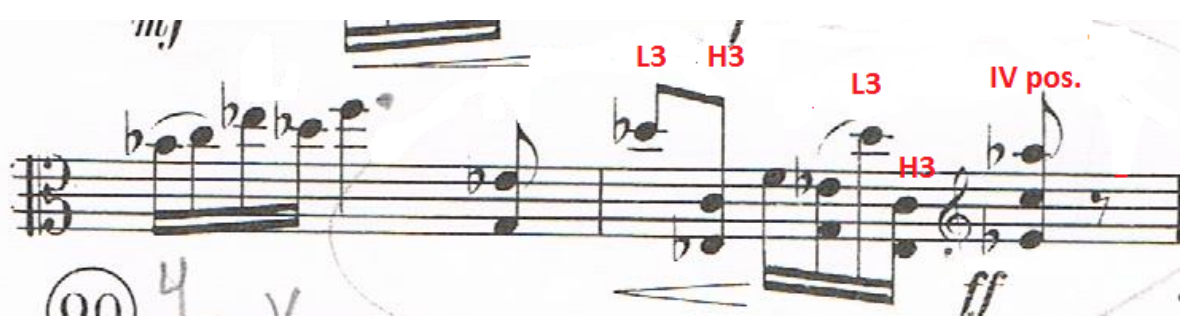

The next example is the passage with the double stops in thirds (see Mus. ex. 79). Challenging enough to play in the allocated tempo, this run is complicated even more by the 
additional request for the flying staccato bow stroke. This technique, a very common feature of Paganini's compositions, was also popularised by Fritz Kreisler ${ }^{87}$, Primrose's friend and colleague. One of the most popular and best known examples of this technique is Kreisler's Schön Rosmarin.

Mus. ex. 79. Darius Milhaud, Deuxiéme Concerto pour Alto et Orchestre, $3^{\text {rd }}$ movement, bars 98-99.

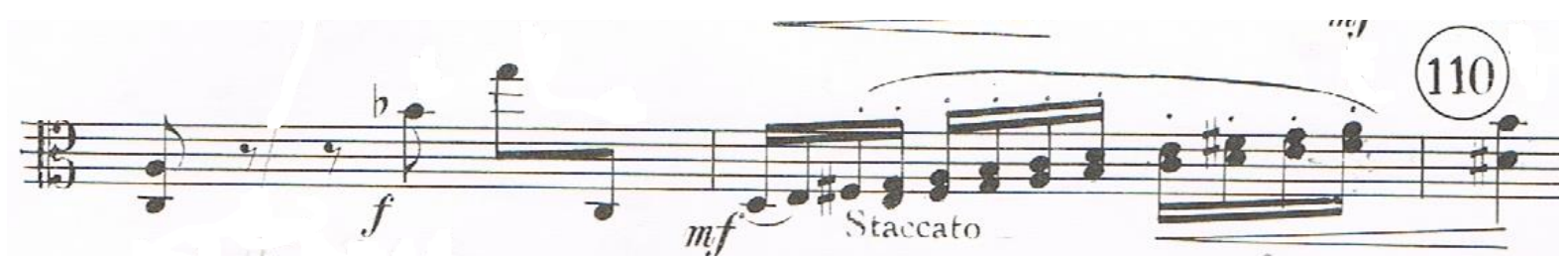

Besides the challenging double stops, there are numerous techniques, which require special attention; amongst them is the descending sequence of arpeggios that is reminiscent of the Paganini's Caprice No. 1 (see Mus. ex. 80).

Mus. ex. 80. Darius Milhaud, Deuxiéme Concerto pour Alto et Orchestre, $3^{\text {rd }}$ movement, bar 117.

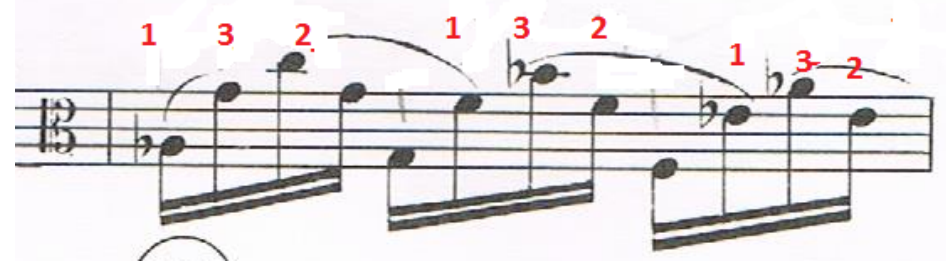

This sequence leads towards the cadenza-like interlude. The viola is left with very little support from the orchestra. Starting at bar 120 , this cadenza is entirely comprised of double stops (see Mus. ex. 81).

\footnotetext{
${ }^{87}$ Fritz Kreisler plays Schön Rosemarin, available from www.allmusic.com/artist/fritz-kreisler-mn0000757095 (accessed 14 November 2014).
} 
Mus. ex. 81. Darius Milhaud, Deuxiéme Concerto pour Alto et Orchestre, $3^{\text {rd }}$ movement, bars $118-123$.

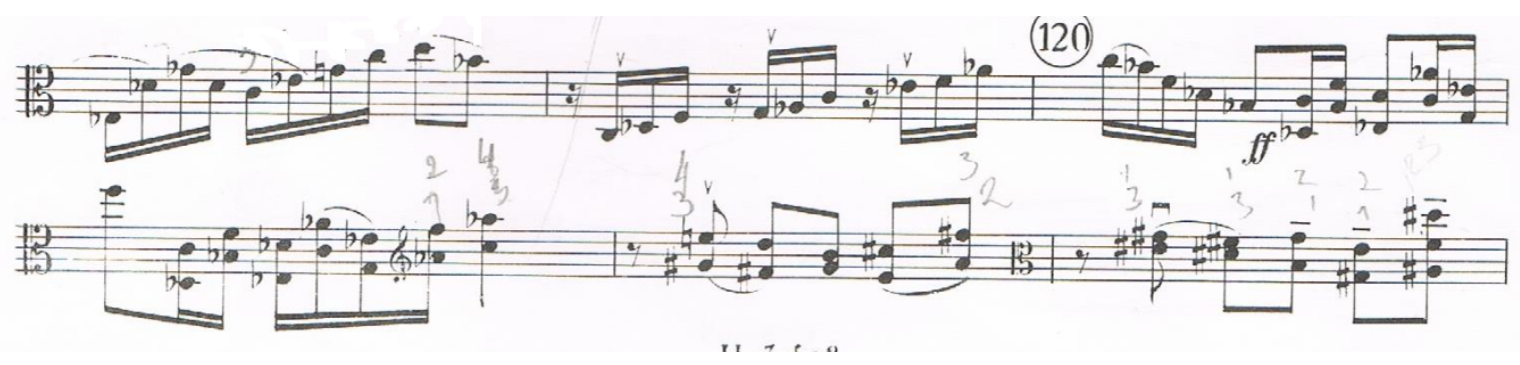

In the development, the second theme is complicated by the two sets of highly challenging double stops followed by the ascending and descending passages, which must be played using the flying staccato bow stroke. In the middle of this theme is a bar, which did not strike me as a particularly difficult place at first sight, but in the process of learning, it proved to be one of the most time consuming challenges (see Mus. ex. 82).

Mus. ex. 82. Darius Milhaud, Deuxiéme Concerto pour Alto et Orchestre, $3^{\text {rd }}$ movement, bar 149.

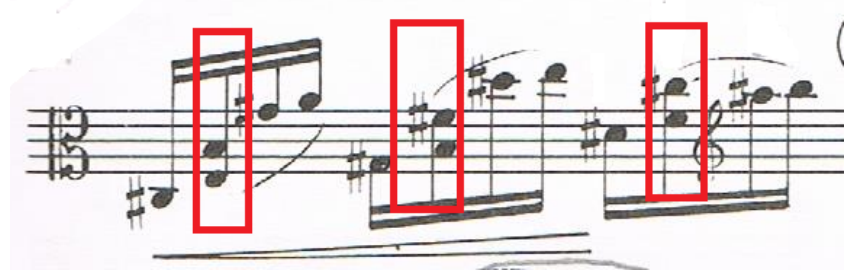

The intervals highlighted in red are double stopped fifth. It not only made this bar challenging in terms of the intonation, but it also affected the tempo. I was surprised to discover the solution, which is more mental than technical. I managed to play this bar in tempo and with good intonation by 'overlooking' the presence of the double stops and concentrating on the general flow of the run and the clean execution of the upper notes. The last four semiquavers of this bar are particularly difficult as there is a long shift in the middle of the four notes from the first position to the fifth position. I came up with exactly the same fingering as indicated by Primrose.

Another 'hidden surprise' awaits the performer near the end of the movement - three sequences of ascending double stops, which are actually concealed four and three string chords (see Mus. ex. 83). 
Mus. ex. 83. Darius Milhaud, Deuxiéme Concerto pour Alto et Orchestre, $3^{\text {rd }}$ movement, bars 162-169.

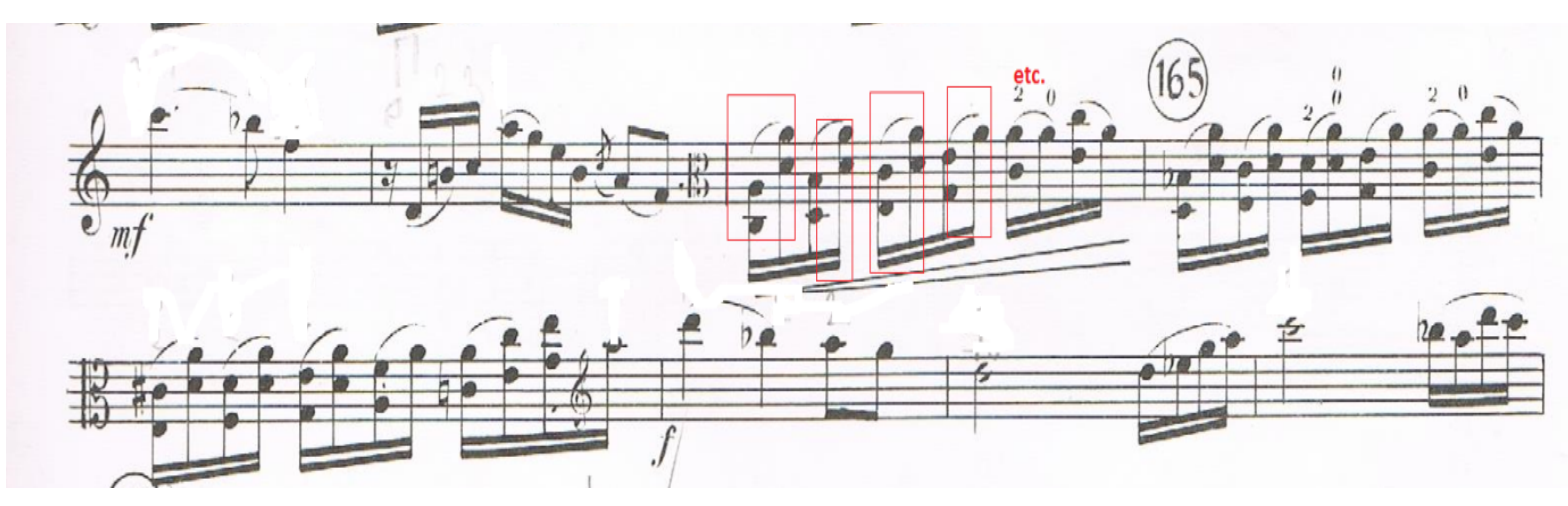

I discovered the idea of the concealed chords when my learning tempo moved towards its final speed and I realised that in the indicated tempo these double stops would sound like chords. It changed my approach towards the bow division, which made this place much easier to play. One final surprise is the very last chord of this movement; once again, the viola is left on its own with a very soft pianissimo chord.

The final movement is a joyful celebration. The character marking of this movement is Avec gaité (with gaiety). The main theme of the movement is written in the character of a gigue, which is very common for the finales of Milhaud's compositions. This theme is contradicted by the second theme in the character of the waltz. In my opinion, this very smart combination of styles is paying homage to Primrose's Scottish heritage and his lifelong competition in virtuosity with the violinists. I think there is also a slight hint of Primrose's musical associations with the major twentieth century figures of the virtuoso world - Jasha Heifetz and Fritz Kreisler, and their German and Viennese backgrounds.

The beginning of the movement, deceitful in its visual simplicity, tempts the soloist to take a very fast tempo (see Mus. ex. 84). This gigue is a full-hearted dance, which very soon progresses from mezzo forte to the fortissimo, in a set of double-stops and chords. 
Mus. ex. 84. Darius Milhaud, Deuxiéme Concerto pour Alto et Orchestre, $4^{\text {th }}$ movement, bars $1-5$.

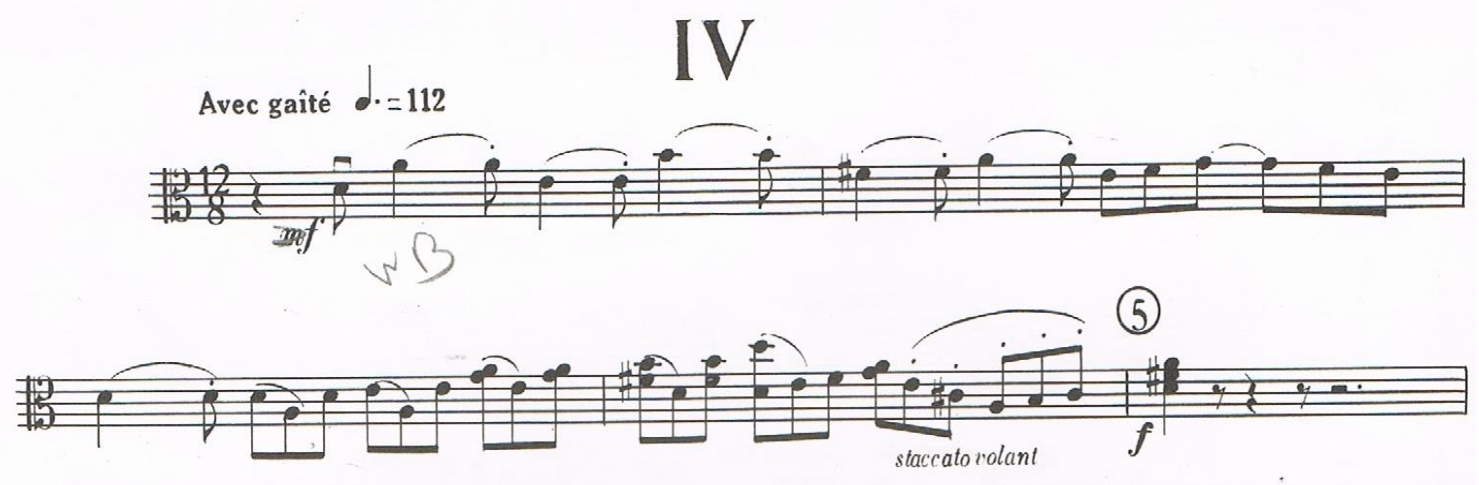

The second theme is a waltz that is elegant and bears a softer dynamic mezzo piano and does not exceed the mezzo forte. The character marking expressif creates further contrast with the main theme (see Mus. ex. 85).

Mus. ex. 85. Darius Milhaud, Deuxiéme Concerto pour Alto et Orchestre, $4^{\text {th }}$ movement, bars 24-28.
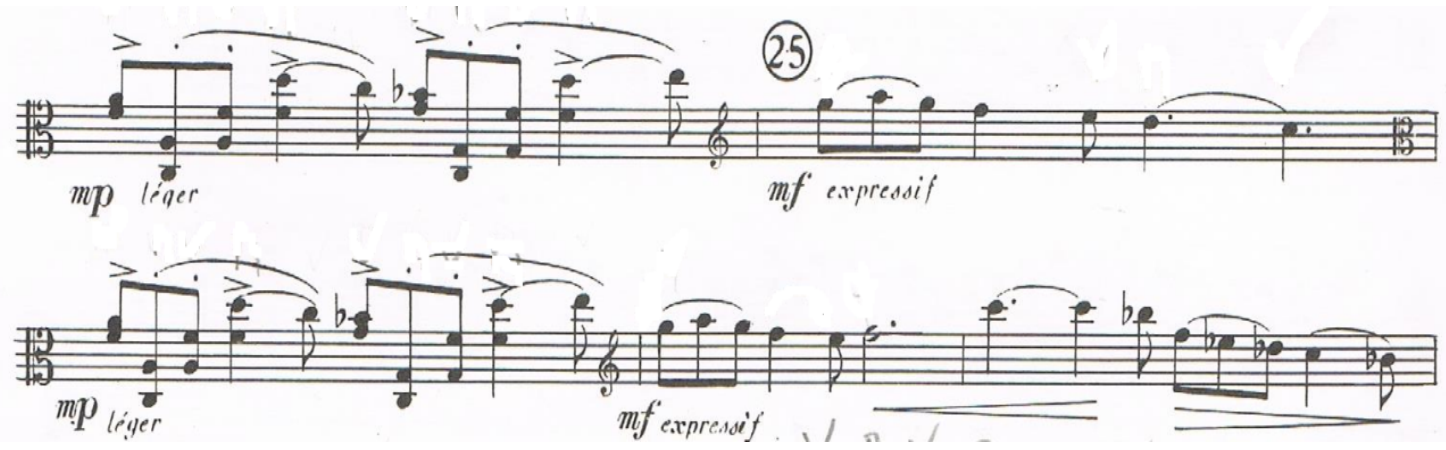

The conclusion of the second theme introduces the first real technical challenge of this movement - an ascending sequence of double stops followed by a very short motif comprising double stops and unavoidable long shifts (see Mus. ex. 86). 
Mus. ex. 86. Darius Milhaud, Deuxiéme Concerto pour Alto et Orchestre, $4^{\text {th }}$ movement, bars 41-50.

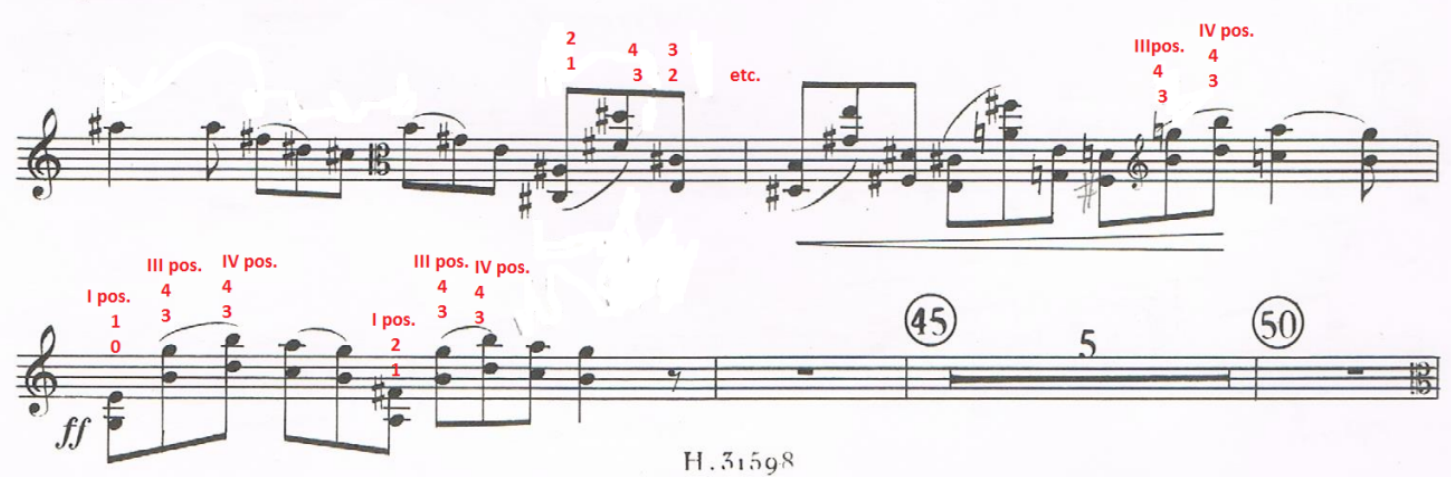

A very valuable suggestion was made by Professor Riseley; he advised me to practice by assembling the two slurred double stops in a chord, then pause and play the next double stop. The pause in this exercise should be used for preparation for the next set of double stops.

The opening of the development looks like a blend of the fast virtuoso runs which could easily be attributed to Paganini's repertoire, and the string of heavy-handed chords are reminiscent of those commonly used by Hindemith (see Mus. ex. 87).

Mus. ex. 87. Darius Milhaud, Deuxiéme Concerto pour Alto et Orchestre, $4^{\text {th }}$ movement, bars 51-58.
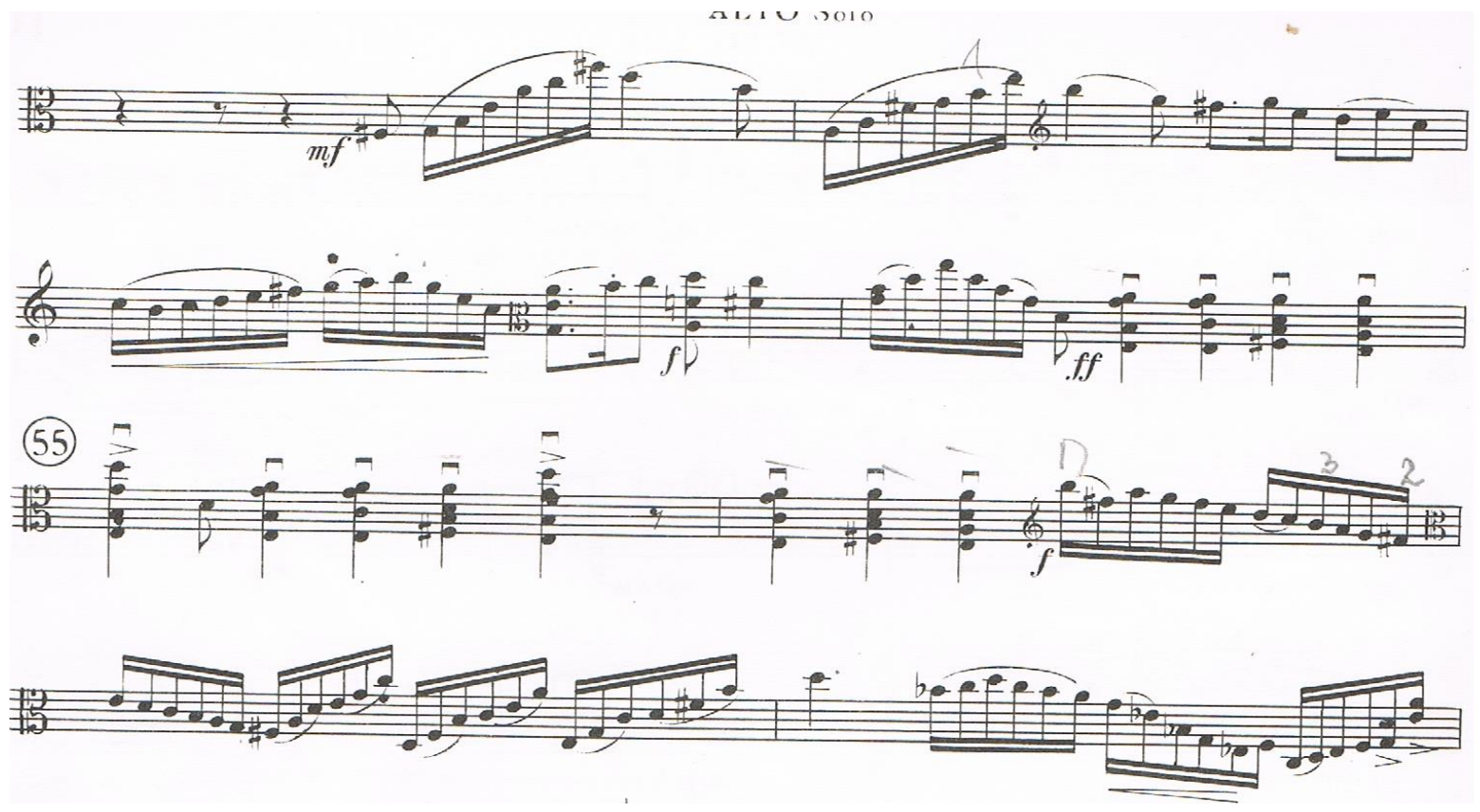
In the development section, Milhaud varies the second theme with the insertions of the harmonics as if picturing the light-hearted whistling of the gentleman on the dance floor. Two almost identical scales in E flat major are differentiated with the subtle discrepancies in the dynamics and the interesting request of the bow strokes (see Mus. ex. 88).

Mus. ex. 88. Darius Milhaud, Deuxiéme Concerto pour Alto et Orchestre, $4^{\text {th }}$ movement, bars 75-78.

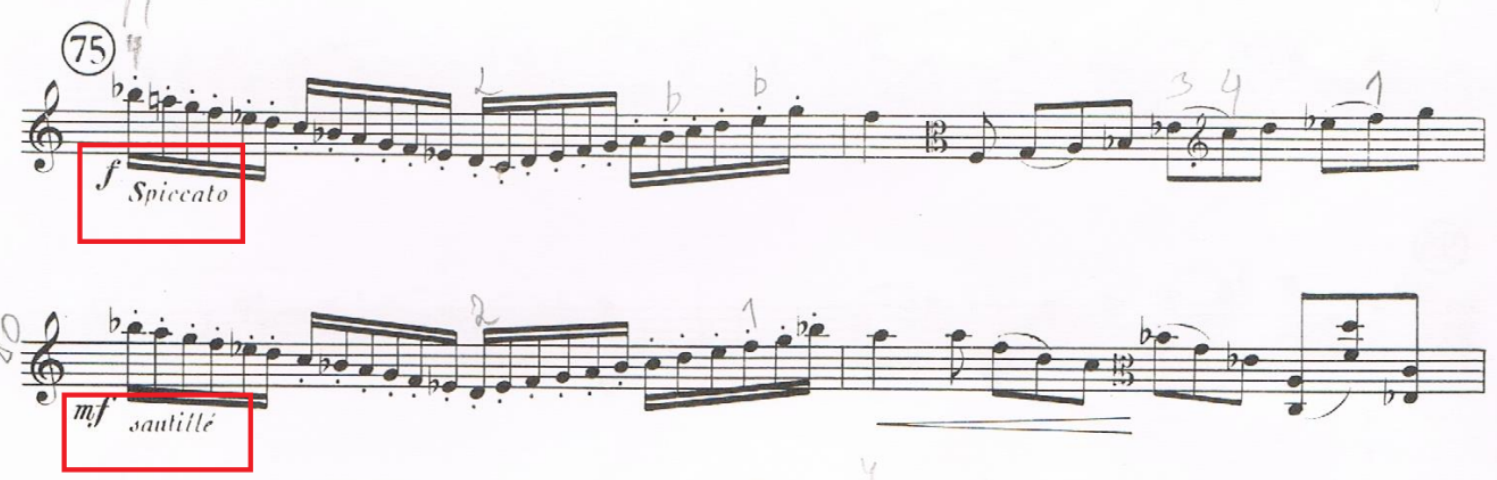

The spiccato bow stroke presumes the usage of the lower part of the bow and that the bow must be 'directed' by the hand and fingers. This is a heavy bow stroke and it is an appropriate request for the forte dynamic. However, I think that the tempo requested by the composer is more suitable for the sautillé bow stroke that Milhaud asked for in the second phrase. The sautillé is suitable for both phrases and can be successfully executed in both cases. Of course, the spicatto is not impossible to use at this speed, but the difference is very subtle and could not be identified by the listeners.

In a similar manner to its use in the exposition, the second theme in the development concludes with an ascending sequence of double stops. Due to the different accidentals, this sequence is more comfortable to play than the first one (see Mus. ex. 89).

Mus. ex. 89. Darius Milhaud, Deuxiéme Concerto pour Alto et Orchestre, $4^{\text {th }}$ movement, bars 79-80.

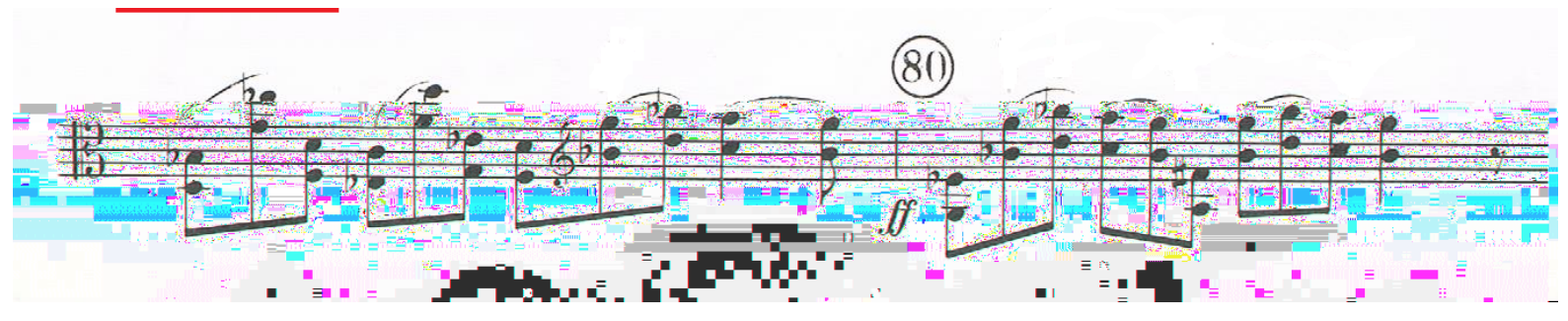


In accordance with tradition, the recapitulation opens with the first theme, which is transferred to an octave higher than in the exposition. Milhaud varies the theme with double stops and harmonics (see Mus. ex. 90).

Mus. ex. 90. Darius Milhaud, Deuxiéme Concerto pour Alto et Orchestre, $4^{\text {th }}$ movement, bars 95-96.

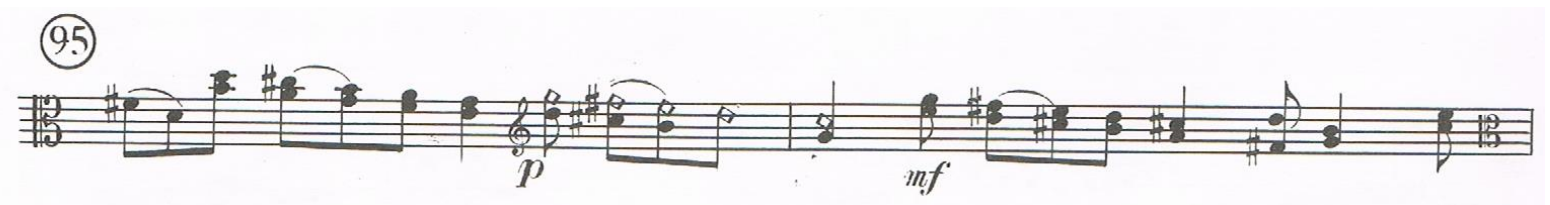

Almost unchanged, the second theme leads to a very short coda, that comprises the combination of rapid semiquavers passages and Hindemith-like chords. In the last bar of this movement Milhaud includes a chord where the top note is a harmonic. This is the last challenge of the concerto - to make the harmonic audible in the very fast tempo. 


\section{Aspects of virtuosity in the viola concertos by Darius Milhaud}

After learning and performing Concerto No.2, I have a better understanding of Milhaud's idea behind the composition. He created an ultimate viola virtuoso concerto by combining the most progressive technical elements of the violin and viola repertoire that he was familiar with. He blended Paganini, the initiator of virtuosity, Hindemith, the performer and composer who 'rediscovered' the viola in the context of contemporary music, and Primrose, the unexcelled virtuoso violist of the twentieth century, into the one of the most challenging viola concertos.

Summarising the virtuoso techniques used by Darius Milhaud in his second concerto, and comparing them with the technical elements from the other items of virtuoso viola repertoire served to dissolve the myth of this concerto being unplayable. At the beginning of my degree, I selected a repertoire that was organised according to the chronological order of the events and of course the second concerto was the last Item on the list. Working through some of the most demanding pieces from the virtuoso viola repertoire, including Paul Hindemith's Konzertmusik Op. 48 and Der Shwanendreher, Paganini's 24 Caprices for violin transcribed for the viola, Paganini's Sonata Per la Grand' Viola, and, of course, Milhaud's Concerto No.1, determined that the second concerto is as demanding as all of the aforementioned pieces put together, but is not unplayable.

Selecting examples of the virtuoso techniques for the comparison was not a problem, as in every movement of this concerto I could recognise an element that can be easily attributed to Paganini or Hindemith. Milhaud was capable of adopting technical elements used by one of his contemporaries (Hindemith), or elements he came across during his violin studies, without losing his identity and musical style.

Most of the virtuoso music includes certain types of double stops. Perhaps one of the most difficult technical elements of Concerto No.2 are double stops. There are two main reasons for this: the order of the intervals, and the string crossing within the set of intervals. In some cases, Milhaud overcomplicated passages of double stops by applying virtuoso bow strokes. One of the best examples is the set of thirds from the second movement of his Concerto No.2, where Milhaud uses flying staccato bow stroke. Paganini very commonly used ascending and descending passages comprising thirds with application of various bow 
strokes and there are numerous examples of this technique in his music. William Primrose, 'the Paganini of the viola of the $20^{\text {th }}$ century', was known for his brilliant execution of this technical element.

Perhaps by adapting stylistic, musical and technical elements used by different composers and performers, Milhaud showed his respect for their works. One of the best examples of this kind of adaptation is the sequence of the chords, which can be attributed to Paul Hindemith. In the fourth movement of his Concerto No. 2, Milhaud used a Hindemith-like sequence of chords. Hindemith used these sequences in almost every piece he wrote for the viola, including Konzertmusik Op. 48 and Der Schwanendreher, and perhaps can be named a creator of this element. Milhaud's version of this technical element is not as challenging as Hindemith's. Milhaud placed all chords in the first position, while Hindemith's sequence of chords has a far more complex structure and progresses to the high position. Another tribute to the great composer and unexcelled virtuoso, Paganini, is the ascending and descending sequences of arpeggios. Milhaud utilised this technique in both of his viola concertos. In the Concerto No. 2, Milhaud built a cadenza-like part of the second movement entirely based on the ascending and descending arpeggios. Paganini used descending and ascending sequences of arpeggios in many of his pieces, including Sonata per la Grand Viola and Caprice No. 1. He was an advanced guitar player and wrote music for the guitar as a solo instrument, and in different combinations of chamber ensembles. It is reasonably easy to imagine that Paganini transferred this technical element from the guitar music to his pieces for violin and viola.

The left hand fingers expansion is one of the most demanding technical elements for the viola. I found that Milhaud was very fond of this technical element and used it extensively in both of his concertos and other pieces for viola. Perhaps the fact that he never played viola and refused to see much difference between the violin and viola encouraged Milhaud to utilise this technique in his music for the viola. In some places I found that the left hand fingers extension used by Milhaud was very difficult, and made the material almost unplayable. This could be attributed to the fact that Milhaud, during his university years as a violinist, studied Paganini's pieces and adopted left hand fingers expansion as a virtuoso technique from his repertoire. Paganini did not use the left hand fingers expansion in his Sonata per la Grand' Viola - the only item he wrote for the viola as a solo instrument. Perhaps the rather large size of his viola prevented Paganini from using this 
technique. Paul Hindemith avoided using the left hand fingers expansion in his music for the viola.

Milhaud used harmonics frequently in his music for the viola, but, unlike Paganini, he utilised harmonics more as an embellishment, rather than building a melody comprised of entire harmonics. The most challenging example of usage of this technical element is in Paganini's Sonata per la Grand' Viola in variation one where Paganini uses harmonics to vary the theme and to create dynamical and tonal contrast. Harmonics used by Milhaud in his Second Concerto are less difficult to execute than the harmonics from Paganini's Sonata per la Grand' Viola. Paganini also used the most extreme upper range of the instrument. Both Milhaud and Hindemith used a very reasonable gamut of positions in their viola music.

Very often, Milhaud uses different positions without any concern about the shifts between positions, and long shifts are often combined with a very fast tempo. Perhaps this is another influence by Paganini, who was well known for his swift shifting technique.

Finding all these similarities in techniques used by Milhaud along with those from Hindemith and Paganini's music and Primrose's transcriptions, is not only to confirm the playability of this concerto; more importantly, it is to confirm that the greatest compositions are derived from the acquaintances with influential contemporaries and timeless legacy of great predecessors. Their vibrant personalities and effortless virtuosity enchanted Milhaud, who created a very fine example of the amalgamation of techniques derived from the compositions of different eras and Milhaud's own experience as an advanced violinist.

It is hard to underestimate the importance of this concerto for the virtuoso viola repertoire - it is another step in the way of the progression of virtuosity in the viola from the twenties to the twenty-first century, which also combines the legacy of three models of virtuosity in viola - Paganini, Hindemith and Primrose. 


\section{Conclusion}

The main goal of my thesis was to link the technical and stylistic elements used by Paganini, Hindemith and Primrose with those used by Milhaud, and to confirm the direct and indirect influence of these three models of virtuosity on his compositions for the viola.

The first hint of the importance and relevance of Paganini to my research was a discovery of Trois Caprices de Paganini, for violin and piano, Op. 97 (1927) in the Catalogue of Works by Darius Milhaud in his autobiography My Happy Life. This confirmed my assumption that Milhaud was familiar with Paganini's works. Considering Primrose's reputation of unexcelled virtuosity and his well-known performances of Paganini's compositions, the link Paganini - Primrose - Milhaud grew stronger with every step of my investigations. Even the fact that I could find very little information about a relationship between Milhaud and Primrose did not contest the influence of both Paganini and Primrose on Milhaud's writing for the viola.

Paul Hindemith transformed the viola from the pleasantries of the classical, and not very exciting, techniques of romantic music into the new forceful power of the $20^{\text {th }}$ century. His approach to the viola, his compositions for the viola and his associations with the most prolific and influential musicians and composers of the $20^{\text {th }}$ century brought the viola up to date with the other virtuoso instruments of that time. The interesting fact is that, despite its centuries long presence, the viola was one of the 'new instruments' that were being developed and re discovered during the $20^{\text {th }}$ century. Milhaud not only utilised some of the techniques that are characteristic of Hindemith's music, but also 'adopted' the forceful style, which is especially present in both his viola concertos.

One of my goals at the beginning of my degree was to perform all the music written by Darius Milhaud for the viola, and I am glad that I managed to complete this task, which also confirmed some of my conclusions regarding Milhaud's understanding of the viola as a solo virtuoso instrument. Throughout his viola compositions Milhaud utilised the top range of virtuoso techniques he was familiar with from his own experience of being an advanced violin student. He has the same approach to the viola as he would to the violin in his early compositions and his second concerto, which was the second-to-last piece he wrote for the viola. However, his every composition bore a 'hint' of style of the performer/composer it 
was written for, or influenced by: from the Bach meets jazz in the Viola Sonata No. 1, Op. 240, to the obvious Hindemith-like character and musical elements in the Concerto for Viola and Orchestra to the Paganini/Primrose-like craziness of virtuosity in Deuxiéme Concerto pour Alto et Orchestre.

Another important aspect of my degree was the necessity and opportunity to extend my repertoire. During my degree, I learned and performed a large number of pieces from the virtuoso viola repertoire, presented two recitals and two lecture recitals in the last two years. Over these four recitals, I performed a selection of caprices by Paganini, a selection of arrangements for viola by Primrose, and various viola works by Darius Milhaud and Paul Hindemith. I devised programmes that ensured an interesting selection of pieces for each recital, that were relevant to my research. In my first recital I performed Hindemith's Der Schwanendreher, Paganini's Caprices No. 3, No. 9, No. 13, No. 16 and No. 20, Milhaud's Sonata for viola and piano No.2, and Paganini's Sonata per la Grand' Viola e Orchestra. This was the most challenging selection of pieces I have ever assembled in one recital. The preparation for this recital and the actual performance helped me to develop a better understanding of my own musical and physical abilities. It also gave an enormous and much needed boost to my confidence.

For my first lecture recital in July 2012, I selected Paul Hindemith's Konzertmusik für Solobratsche und größeres Kammerorchester Op. 48 (1930), and Milhaud's Viola Concerto No. 1 Op. 108 (1929). The programme for this recital was selected with the intention of emphasising the historical connection between these two viola concertos written by Paul Hindemith and Darius Milhaud. This was followed by my second lecture recital in November 2012. The second lecture recital comprised chamber music written by Darius Milhaud featuring viola: Sonatina for violin and viola, Op. 226 (1941), Concertino d'été for viola and chamber orchestra, Op. 311 (1951), Sonatina for viola and cello, Op. 378 (1959) and Elegie pour Pierre for viola, timpani and 2 percussions, Op. 416 (1965). I presented this selection of Milhaud's works for viola in chronological order, and provided brief information about the people to whom these pieces were dedicated. I was very fortunate to be joined for this recital by staff members of the New Zealand School of Music, Professor Martin Riseley, and Dr Jian Liu. In my final recital, I presented pieces by all four composers/ performers featured in my dissertation: Paul Hindemith's Sonata for viola and piano (1939), two transcriptions for the viola by William Primrose -- 'Aria (Cantilena)' from Bachianas Brasileiras No. 5 by 
Heitor Villa-Lobos, and Arthur Benjamin's Jamaican Rumba, Darius Milhaud's Concerto No.2 for viola and orchestra, Op. 340 (1954-1955) and Paganini's Caprice No. 24. And of course, the most important of all performances was the premiere of Deuxiéme Concerto pour Alto et Orchestre with the NZSM orchestra in Wellington. It was a real physical challenge, and I am struggling to compare the technical and musical intensity of this concerto with any other work of the same length for the viola. Not surprisingly, every movement received different feedback from the audience and fellow musicians. The second movement was favoured by many for its lightness and beauty of melodic lines, the fourth movement was liked for its bravura character and sheer display of virtuosity, and first and third movements were found by many to be too mechanical and industrial in their character. Everyone who did give me their feedback made one similar point - they certainly would listen to it again. Therefore, I consider my venture a successful step on the way to re-introducing this concerto to the virtuoso viola repertoire of the $21^{\text {st }}$ century. 


\section{Acknowledgements}

During my degree, I was given some amazing opportunities: to perform alongside some of the best musicians in New Zealand, to travel overseas to represent New Zealand School of Music, and New Zealand and Australia Viola Society, at the International Viola Conference and to meet Milhaud's remaining family members.

I would like to thank Professor Martin Riseley who guided me through the performance part of my degree and shared with me his expertise on Paganini.

Meeting Daniel and Nadine Milhaud afforded me the unreal experience of touching history. I was kindly invited by Nadine and Daniel to their house in Paris where, during a very cordial lunch, I had an interview with Daniel Milhaud. I found that Daniel was not very familiar with his father's viola works and could provide very little information about Darius Milhaud's associations with William Primrose, but he gave me a priceless insight into the character of his father, which I made use of during my further investigations.

Another wonderful opportunity was a chance to play Milhaud's Concerto No.2 with the NZSM orchestra. The support of the conductor Kenneth Young, who is well known for his interest in rarely-performed compositions, insured the success of this performance. Bringing back to life one of the most demanding concertos of the virtuoso viola repertoire was a wonderful experience that was important for both my career and the viola virtuoso repertoire.

Professional editor, Owen Kavanagh, of Jera Editing Services, provided copyediting and proofreading services, according to the guidelines laid out in the university-endorsed national 'Guidelines for editing research theses', published as part of the Australian standards for editing practice. 
Applebaum, Samuel and Sada. The Way They Play. Vol. 1. Neptune City: Paganiniana Publications, 1972.

Applebaum, Samuel and Sada

http://www.ccrma.stanford.edu/marl/CASL/Files/applebaum.html accessed 06/06/11.

Axelrod, Herbert R. and Sheppard, Leslie. Paganini. Neptune City: Paganiniana Publications, 1979.

Axelrod, Herbert R. and Axelrod, Todd M. Heifetz. Neptune City: Paganiniana Publications, 1990.

Baillot, Pierre Marie Francois de Sales. The Art of The Violin. Evanston: Northwestern University Press, 1991.

Barizza, Andrea and Morabito, Fulvia, eds. Nicoló Paganini. Diabolus in Musica. Brepols: Turnhout MMX, 2010.

Benjamin, Arthur. Jamaican Rumba, arr. William Primrose, viola and piano. New York: Boosey \& Hawkes, 1954.

Benjamin, Arthur. Jamaican Rumba, arr. William Primrose, violin and piano. London: Boosey \& Hawkes, 1944.

Berlioz, Hector. Harold in Italy, Symphony in Four Parts with Viola Obbligato, Opus 16, 1834.

Bianchi, Luigi Alberto. 'Virtuoso viola technique in the work of Rolla and Paganini'. Nuova rivisista musicale italiana Vol. 9, no. 1, 1975, pp. 10-34.

Charleston Chamber Music Society http://www.charlestonchambermusic.org/?page_id=68 accessed 12/02/2013.

Collaer, Paul. Darius Milhaud. San Francisco: San Francisco Press, 1988.

Cuneo, Monica. Alessandre Rolla and the Viola. http://www.viola -inmusic.com//Alessandro-Rolla.html accessed 08/02/2016 
Dalton, David. Playing the Viola. Conversations with William Primrose. Oxford: Oxford University Press, 1988.

Day, Lillian. Paganini of Genoa. London: Victor Gollancz, 1966.

Doktor, Paul. http://www.answers.com/topic/paul-doktor-classical-musician accessed 29/06/16.

Drake, Jeremy 'Milhaud, Darius', in the Grove Music Online, www.oxfordmusiconline.com, accessed 12/01/2016.

Eisen, Cliff. 'The Rise (and Fall) of the Concerto Virtuoso in the Late Eighteenth and Nineteenth Centuries', in Simon P. Keefe (ed.) The Cambridge Companion to the Concerto, Ney York: Cambridge University Press, 2005.

Girard, J.R., 'Hector Berlioz's "Harold en Italie"' A Performance Guide available from https://urresearch.rochester.edu/fileDownloadForlnstitutionalltem.action. by JR Girard 2012 accessed 26/02/2015

Grout, Donald Jay. 'Chapter XX. The Twentieth Century. Hindemith', in A History of Western Music, revised edition. New York: W. W. Norton \& Company, pp. 684-688.

Hindemith, Paul. Concert Music for Viola and Chamber Orchestra Op. 48, 1930, E. Strahoff (ed.), Moscow: МУзЫКА, 1976.

Hindemith, Paul. Konzertmusik für Solobratsche und Größeres Kammerorchester Op. 48, 1930, Leipzig: Edition Schott, 1997.

Hindemith, Paul. Der Schwanendreher. Konzert nach alten Volksliedern für Bratsche und kleines Orchester, Paul Hindemith (ed.), piano reduction, Mainz: Schott's Söhne, 1936. Hindemith, Paul. Der Schwanendreher. Konzert nach alten Volksliedern für Bratsche und kleines Orchester 1935. Partitur (Orchesterstimmen nach Vereinbarung). Mainz: Schott's Söhne, 1936.

Hindemith, Paul. A Composer's World. Horizons and Limitations. Cambridge: Harvard University Press, 1953.

Hindemith, Paul. The craft of musical composition. Theoretical part. Book 1. New York, London: Associated Music Publishers, Scott \& Co., 1945.

Hindemith, Paul. website: www.paul-hindemith.org/ accessed 05/09/2010.

Hindemith, Paul - FHI Berlin: w3.rz-berlin.mpg.de/comp /Hindemith.htm accessed 05/09 /2010. 
Hindemith, Paul. Classical Net Basic Repertoire List: Paul Hindemith:

www.classical.net/music/comp.Ist/hindemith.php accessed 20/10/2010.

Hindemith, Paul - Bio, Albums, Pictures-Naxos Classical Music:

www.naxos.com/person/Paul_Hindemith_23323/23323.htm accessed 10/10/2010

Hindemith, Paul. Orchestral Works. Geraldine Walter viola, San Francisco Symphony.

Gewandhausorchester Leipzig,conductor Herbert Blomsted, DECCA, 475 264-2DTR3,

1998(CD1), 1993(CD2), 2000(CD3) Decca Music Group Limited, A Universal Music Company.

Hindley, Geoffrey, (ed.) 'Music in Germany and Austria. Paul Hindemith. The development of his music. Hindemith's contemporaries' in The Larousse Encyclopaedia of Music. London, New York, Sydney, Toronto: The Hamlyn Publishing Group 1971, pp. 406-410.

Hoppennot, Henry http://daniellathompson.com/Texts/Le_Boeuf/boeuf.pt.30.htm accessed 20/09/2010.

Iliescu, Mihu. 'Aspects of virtuosity in the music of the $20^{\text {th }}$ century'. Analyse musicale, Vol. 52, Dec. 2005, pp. 32-37.

Kater, Michael H. Composers of the Nazi Era. Eight Portraits. New York, Oxford: Oxford University Press, 2000.

Kelly, Barbara L. Tradition and style in the works of Darius Milhaud 1912-1939. Aldershot: Ashgate Publishing Limited, Gower House, 2000.

Kemp, Ian. Hindemith. Oxford Studies of Composers. Vol.6. New York, Toronto: Oxford University Press, 1970.

Kendall, Alan. Paganini: A Biography . London, Chappell: Elm Tree Books, 1982

Kreisler, Fritz. Schön Rosemarin, available from www.allmusic.com/artist/fritz-kreislermn0000757095 accessed 14/11/2014.

Le Diagon- Jacquin, Laurence. 'Virtuosity and inventiveness in the pianistic universe of the $19^{\text {th }}$ century'. Analyse musicale, Vol. 52, Dec. 2005, pp. 62-75.

Leppert, Richard. 'Cultural Contradiction, Idolatry, and the Piano Virtuoso: Franz Liszt', in James Parakilas (ed.), Piano Roles: Three Hundred Years of Life with the Piano, New Haven, London: Yale University Press, 1999. 
Liszt, Franz. Etudes d'execution transcendante d'apres Paganini, S.140, 1838, available from hppts://www.hyperion-records.co.uk/tw.asp? w=W6438, accessed 29/06/2016

Lochner, Louis P. Fritz Kreisler. London: Rockliff, 1951.

Luttmann, Stephen. Paul Hindemith. A Research and Information Guide. New York: Routledge Music Bibliographies, 2009.

Martinson, Kenneth. 'The Viola Music of Darius Milhaud'. Available from

http://www.wiu.edu/music/articles/Milhaud.htm accessed 28/05/2011

Martinson, Kenneth http://kennethmartinson.com/pdf/review_column_12.pdf accessed 4/05/11 accessed 29/05/2011,

Milhaud, Darius. My Happy Life. London, New York: Marion Boyars Publishers, 1995.

Milhaud, Darius. Notes Sans Musique. Paris: Rene Julliard, 1949.

Milhaud, Darius. Notes without Music. Donald Evans (trans.), Rollo H. Myers (ed.), London:

Dennis Dobson, 1950.

Milhaud,Darius. Deuxiéme Concerto pour alto et orchestra, A William Primrose, the manuscript of the score, available from William Primrose archive (PIVA) at the Brigham Young University in Utah, USA.

Milhaud, Darius. Concertino D'été. Partition D'orchestre. Paris: Heugel et Cie, 1952.

Milhaud, Darius. Concerto pour alto et orchestra. Edition pour alto et piano. Paul Hindemith (ed.) Paris: Universal Edition Nr.3718, 1958.

Milhaud, Darius. Elégie pour Pierre 'Opus416' (1965) for viola, timpani, and 2 percussionists. Urtext. Kenneth Martinson (ed.), Gainesville, FL: Gems Music Publications, 2010.

Milhaud, Darius. Deuxième Concerto pour Alto et Orchestre. Reduction pour Piano et Alto.

Paris: Heugel et Cie, 1958.

Milhaud, Darius. Milhaud, Darius (1892-1974): Viola Works. Kenneth Martinson, viola;

Nicholas Kitchen, violin; Frank Epstein, timpani; Craig McNutt and Robert Schulz, percussion. Centaur Records, Inc. 2001. 
Morgan, Lee Ann Jolley. 'The William Primrose transcriptions: Primrose's rise to eminence and the expansion of the viola repertoire through transcriptions.' DMA diss., University of Washington, 2007.

Monteux, Pierre http://www.britannica.com/EBchecked/topic/390817/Pierre-Monteux accessed 2/06/2011

Neill, Edward. Paganini, Nicolò, in Grove Music Online, www.oxfordmusiconline.com accessed 13/01/2016.

Nelson, Sheila M. The Violin and Viola. London: Ernest Benn Limited, 1972.

Neumeyer, David. The Music of Paul Hindemith. New Haven, London: Yale University Press, 1986.

Paganini, Nicolò. Violin Concerto in B minor, Opus 7, violin and piano, Ney Tibor (ed.)

Budapest: Editio Musica,1968.

Paganini, Nicolò. Le Streghe. Introduzione, Tema con Variazioni e Finale, Opus. 8, 1813, Tibor Ney (ed.) Budapest: Editio Musica, 1968

Paganini, Nicolò. 24 Capricci per violin solo Op. 1, Ruggiero Ricci (ed.) Budapest: Editio Musica, 1984.

Paganini, Nicolò. 24 Caprices Op. 1, L. Raby (trans.) Viola. New York: Kalmus, 1985

Paganini, Nicolò. 24 capricci per violino solo, Performers' Facsimiles, 244. New York: Broude Brothers, 2002

Paganini, Niccoló. La Campanella. William Primrose (trans.) Viola and Piano. Ed 10414 ISMN M-2201-2206-4. London: Schott \& Co. Ltd., 1952.

Paganini, Niccoló. Sonata per la Grand'Viola e Orchestra. Piano Reduction Ulrich Drüner (ed.) Mainz: Schott Music International, 1974.

O'Dea, Jane. Virtue or Virtuosity. Explorations in the Ethics of Musical Performance. London: Greenwood Press, 2000

Palmer, David Lee. 'Virtuosity as rhetoric: Agency and transformation in Paganini's mastery of the violin'. Quarterly journal of speech, Vol. 84, No. 3, 1998, pp. 341-357. 
Poniatowska, Irena. 'Virtuosity and national elements in the instrumental music of the 19th century'. Revue belge de musicology/Belgish tijdschrift voor muziekwetenschap, Vol.60 pp. 99-113.

Potter, Tully. William Primrose and his violas, available fromhttp://tarisio.com/cozioarchive/cozio-carteggio/william-primrose-and-his-instruments accessed 26/01/2016.

Primrose, William. Letter dated 11.4.9 - October 20, 1979, to Maurice Riley from Primrose. Primrose, William. 'Ruminations of the viola'. Journal of the Violin Society of America, Vol. 5, no. 1,1979 , pp. 153-59.

Primrose, William. 'Heifetz,' in Heifetz, 3rd rev. edition, Herbert R. Axelrode (ed.). Neptune City: Paganiniana Publications, 1990.

Primrose, William. 'The Viola', in Yehudi Menuhin and William Primrose. Violin and Viola, London: Macdonald and Jane's, 1976, pp. 171-188.

Primrose, William. Walk on the North Side. Memories of a Violist. Provo: Brigham Young University Press, 1978.

The Primrose International Viola Archive at Brigham Young University: http://music.lib.byu.edu/PIVA/ accessed 20/05/11.

Pulver, Jeffrey. Paganini. The romantic virtuoso. London: Herbert Josef Limited, 1936.

Reynaud, Cecile. 'Misery and artistic accomplishment in Romantic virtuosity' in Romantisme: Revue du dix-neuvieme siècle. Paris: 2005.ISBN: 2-200-92047-4. Pages: 3-17

Ricards, Guy. Hindemith, Hartmann and Henze. London: Phaidon Press Limited, 1995. Ricci, Ruggiero. Left-Hand Violin Technique, New York: G.Schirmer, 1988

Righini, Mauro. 'Paganini, Berlioz and the Grand Viola' in Quaderni dell'Istituto di Studi Paganiniani. Vol. 13, 2001, pp. 62-69. 2001.

Henry Roth, Violin Virtuosos. From Paganini to the $21^{\text {st }}$ Century, Los Angeles: California Classics Books, 1997.

Sadie, Stanley (ed. ) The New Grove Dictionary of Music and Musicians. New York: MacMillan Publishing, 2001.

Salzedo, S. L. Paganini's Secret at Last. London: Nicholson \& Watson, 1946. 
Skelton, Geoffrey. Paul Hindemith. The Man Behind the Music. London: Victor Gollancz, 1975.

Skelton, Geoffrey (ed.) Selected Letters of Paul Hindemith. New Haven, London: Yale University Press, 1995.

Stratton, Stephen S. Nicoli Paganini. His life and work. Westport, Connecticut: Greenwood Press, 1971.

Sudgen, John. Niccolo Paganini. Supreme Violinist or Devil's Fiddler? Great Britain: Midas Books, 1980

Tertis, Lionel. My Viola and I. A complete autobiography. London: Elek Books Limited, 1975. Veinus, Abraham. Victor book of Concertos. New York: Simon and Shuster, 1948.

Zank, Stephen. 'The piano in the Concert Hall'. In James Parakilas, Piano Roles. A new history of the Piano. New Haven, London: Yale University Press, 2001, pp. 237-281. 